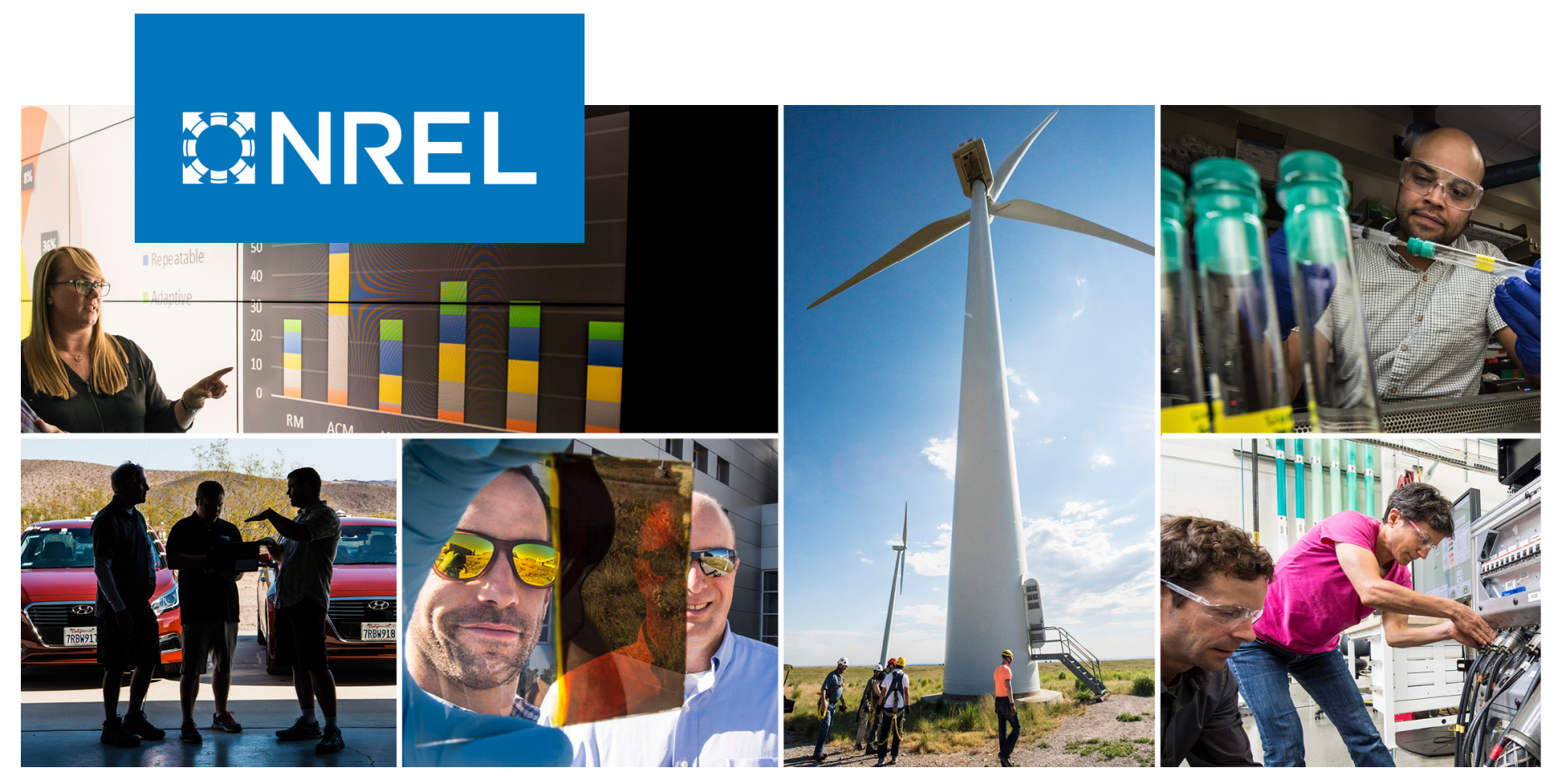

\title{
U.S. Solar Photovoltaic System and Energy Storage Cost Benchmarks: Q1 2021
}

Vignesh Ramasamy, David Feldman, Jal Desai, and Robert Margolis

NREL is a national laboratory of the U.S. Department of Energy Office of Energy Efficiency \& Renewable Energy

Operated by the Alliance for Sustainable Energy, LLC

This report is available at no cost from the National Renewable Energy Laboratory (NREL) at www.nrel.gov/publications.
Technical Report

NREL/TP-7A40-80694

November 2021 


\section{GNREL}

\section{U.S. Solar Photovoltaic System and Energy Storage Cost Benchmarks: Q1 2021}

Vignesh Ramasamy, David Feldman, Jal Desai, and Robert Margolis

\section{Suggested Citation}

Ramasamy Vignesh, David Feldman, Jal Desai, and Robert Margolis. 2021. U.S. Solar Photovoltaic System and Energy Storage Cost Benchmarks: Q1 2021. Golden, CO: National Renewable Energy Laboratory. NREL/TP-7A40-80694. https://www.nrel.gov/docs/fy220sti/80694.pdf.

NREL is a national laboratory of the U.S. Department of Energy Office of Energy Efficiency \& Renewable Energy Operated by the Alliance for Sustainable Energy, LLC

This report is available at no cost from the National Renewable Energy Laboratory (NREL) at www.nrel.gov/publications.

Contract No. DE-AC36-08GO28308
Technical Report NREL/TP-7A40-80694

November 2021

National Renewable Energy Laboratory 15013 Denver West Parkway Golden, CO 80401 303-275-3000 • www.nrel.gov 


\section{NOTICE}

This work was authored by the National Renewable Energy Laboratory, operated by Alliance for Sustainable Energy, LLC, for the U.S. Department of Energy (DOE) under Contract No. DE-AC36-08GO28308. Funding provided by the U.S. Department of Energy Office of Energy Efficiency and Renewable Energy Solar Energy Technologies Office. The views expressed herein do not necessarily represent the views of the DOE or the U.S. Government.

This report is available at no cost from the National Renewable Energy Laboratory (NREL) at www.nrel.gov/publications.

U.S. Department of Energy (DOE) reports produced after 1991 and a growing number of pre-1991 documents are available free via www.OSTI.gov.

Cover Photos by Dennis Schroeder: (clockwise, left to right) NREL 51934, NREL 45897, NREL 42160, NREL 45891, NREL 48097, NREL 46526.

NREL prints on paper that contains recycled content. 


\section{List of Acronyms}

AC

BESS

BLS

BOS

CAPEX

DC

DOE

EPC

HVAC

LCOE

LCOS

LCOSS

Li-ion

$\mathrm{MW}_{\mathrm{AC}}$

$M W_{D C}$

NREL

O\&M

OPEX

PII

PV

Q

RTE

SG\&A

SOC

USD

$\mathrm{V}_{\mathrm{DC}}$

$\mathrm{W}_{\mathrm{AC}}$

$\mathrm{W}_{\mathrm{DC}}$ alternating current

battery energy storage system

U.S. Bureau of Labor Statistics

balance of system

capital expenditures

direct current

U.S. Department of Energy

engineering, procurement, and construction

heating, ventilating, and air conditioning

levelized cost of energy

levelized cost of storage

levelized cost of solar-plus-storage

lithium-ion

megawatts alternating current

megawatts direct current

National Renewable Energy Laboratory

operation and maintenance

operating expenditures

permitting, inspection, and interconnection

photovoltaic(s)

quarter

round-trip efficiency

selling, general, and administrative

state of charge

U.S. dollars

volts direct current

watts alternating current

watts direct current 


\section{Executive Summary}

This report benchmarks installed costs for U.S. solar photovoltaic (PV) systems as of the first quarter of 2021 (Q1 2021). We use a bottom-up method, accounting for all system and project development costs incurred during installation to model the costs for residential, commercial, and utility-scale PV systems, with and without energy storage. We attempt to model typical installation techniques and business operations from an installed-cost perspective. Costs are represented from the perspective of the developer/installer; thus, all hardware costs represent the price at which components are purchased by the developer/installer and do not account for preexisting supply agreements or other contracts. Importantly, the benchmarks also represent the sales price paid to the installer. Therefore, they include profit in the cost of the hardware; ${ }^{1}$ the profit the installer/developer receives is reported as a separate cost category on top of all other costs to approximate the final retail price paid to the installer/developer. Benchmarks also assume a business environment without any impact from the novel coronavirus pandemic. Finally, our benchmarks are national averages calculated using average values across all states. Table ES-1 summarizes the first-order benchmarking assumptions.

Table ES-1. Benchmarking Assumptions

\begin{tabular}{|c|c|c|}
\hline Unit & \multicolumn{2}{|l|}{ Description } \\
\hline Values & \multicolumn{2}{|l|}{2020 U.S. dollars (USD) ${ }^{a}$} \\
\hline $\begin{array}{l}\text { System } \\
\text { sizes }\end{array}$ & \multicolumn{2}{|c|}{$\begin{array}{l}\text { PV systems are quoted in direct current (DC) terms; inverter prices are converted by DC- } \\
\text { to-alternating current }(\mathrm{AC}) \text { ratios; residential storage systems are quoted in terms of } \\
\text { nameplate kilowatt-hours and commercial/utility storage systems are quoted in terms of } \\
\text { usable kilowatt-hours or megawatt-hours (kWh or MWh) of storage or the number of hours } \\
\text { of storage at peak capacity. }\end{array}$} \\
\hline PV Sector & Description & Size Range \\
\hline Residential & Residential rooftop systems, monocrystalline silicon modules & $3 \mathrm{~kW}-11 \mathrm{~kW}$ \\
\hline Commercial & $\begin{array}{l}\text { Commercial rooftop with ballasted racking and fixed-tilt ground- } \\
\text { mounted systems, monocrystalline silicon modules }\end{array}$ & $100 \mathrm{~kW}-2 \mathrm{MW}$ \\
\hline Utility-scale & $\begin{array}{l}\text { Ground-mounted systems, monocrystalline silicon modules, fixed-tilt } \\
\text { and one-axis tracking }\end{array}$ & $5-100 \mathrm{MW}$ \\
\hline
\end{tabular}

a The dollar-per-watt total cost values are benchmarked as two significant figures, because the model inputs, such as module and inverter prices, use two significant figures.

Based on our bottom-up modeling, the Q1 2021 PV and energy storage cost benchmarks are those listed in Table ES-2:

\footnotetext{
${ }^{1}$ Profit is one of the differentiators of "cost" (aggregated expenses incurred by a developer or installer to build a system) and "price" (what an end user pays for a system).
} 
Table ES-2. Q1 2021 PV and Energy Storage Cost Benchmarks

\begin{tabular}{|c|c|}
\hline Cost Benchmarks ${ }^{a}$ & PV System \\
\hline \multicolumn{2}{|l|}{ Residential Systems } \\
\hline$\$ 2.65 / \mathrm{W}_{\mathrm{DC}}\left(\right.$ or $\left.\$ 3.05 / \mathrm{W}_{\mathrm{AC}}\right)$ & 7.15-kWDC rooftop PV \\
\hline$\$ 4.26 / \mathrm{W}_{\mathrm{DC}}-\$ 4.72 / \mathrm{W}_{\mathrm{DC}}$ & 7.15-kWDC rooftop PV with $5 \mathrm{kWDC} / 12.5 \mathrm{kWh}^{\mathrm{b}}$ nameplate of storage \\
\hline \multicolumn{2}{|l|}{ Commercial Systems } \\
\hline$\$ 1.56 / \mathrm{W}_{\mathrm{DC}}\left(\right.$ or $\left.\$ 1.79 / \mathrm{W}_{\mathrm{AC}}\right)$ & 200-kW $\mathrm{DC}$ rooftop PV \\
\hline$\$ 1.64 / \mathrm{W}_{\mathrm{DC}}\left(\right.$ or $\left.\$ 1.88 / \mathrm{W}_{\mathrm{AC}}\right)$ & $500-k W_{D C}$ ground-mounted PV \\
\hline$\$ 1.97 / \mathrm{WDC}_{\mathrm{DC}}-\$ 2.06 / \mathrm{W}_{D C}$ & $\begin{array}{l}\text { 1-MWDC ground-mounted PV colocated with } 600 \mathrm{kWDC} / 2.4 \mathrm{MWh} \text { usable of } \\
\text { storage }\end{array}$ \\
\hline \multicolumn{2}{|l|}{ Utility-Scale Systems } \\
\hline$\$ 0.83 / \mathrm{W}_{\mathrm{DC}}\left(\right.$ or $\left.\$ 1.09 / \mathrm{W}_{\mathrm{AC}}\right)$ & 100-MW $\mathrm{DC}$ fixed-tilt utility-scale PV \\
\hline$\$ 0.89 / \mathrm{W}_{\mathrm{DC}}\left(\right.$ or $\left.\$ 1.14 / \mathrm{W}_{\mathrm{AC}}\right)$ & 100-MW $\mathrm{DC}$ one-axis-tracking utility-scale PV \\
\hline$\$ 1.67 / \mathrm{W}_{D C}-\$ 1.68 / \mathrm{W}_{D C}$ & $\begin{array}{l}100-M W_{D C} \text { one-axis tracker PV colocated with } 60 \mathrm{MW} W_{D C} / 240 M M_{\text {usable }} \\
\text { of storage }\end{array}$ \\
\hline
\end{tabular}

a Cost/Watt DC (WDC) of PV-plus-storage systems are estimated using PV capacity to reflect the additional cost required to install hybrid systems over installing stand-alone PV systems. The cost range shows the difference in cost between DC-coupled and AC-coupled systems.

${ }^{b}$ All energy storage capacity rating mentioned in this report are in DC.

It should be noted that the interconnection capacity of all these systems is assumed to be equal to the total AC capacity of the system. All data relevant to the reported results in this report can be found in the NREL Data Catalog. ${ }^{2}$ Figure ES-1 (page vi) compares our Q1 2021 PV-only benchmarking results to the Q1 2020 National Renewable Energy Laboratory benchmarking analyses. $^{3}$

Between 2020 and 2021, there were 3.3\% (\$0.09/W), 10.7\% (\$0.19/W), and 12.3\% (\$0.13/W) reductions (in $2020 \mathrm{USD}$ ) in the residential, commercial rooftop, and utility-scale (one-axis) PV system cost benchmarks respectively. Balance of system (BOS) costs have either increased or remained flat across sectors, year-on-year, unlike in previous benchmarking reports, which generally have reported declining BOS costs. The increase in BOS cost has been offset by a $19 \%$ reduction (in 2020 USD) in module cost. Overall, modeled PV installed costs across the three sectors have declined compared to our Q1 2020 system costs. Table ES-3 shows the benchmarked values for all three sectors and the drivers of cost decreases and increases.

2 “Data File (U.S. Solar Photovoltaic BESS System Cost Benchmark Q1 2020 Report)” NREL, https://data.nrel.gov/submissions/158.

${ }^{3}$ Appendix B summarizes benchmark results for all previous NREL benchmark analyses (2010-2021). 


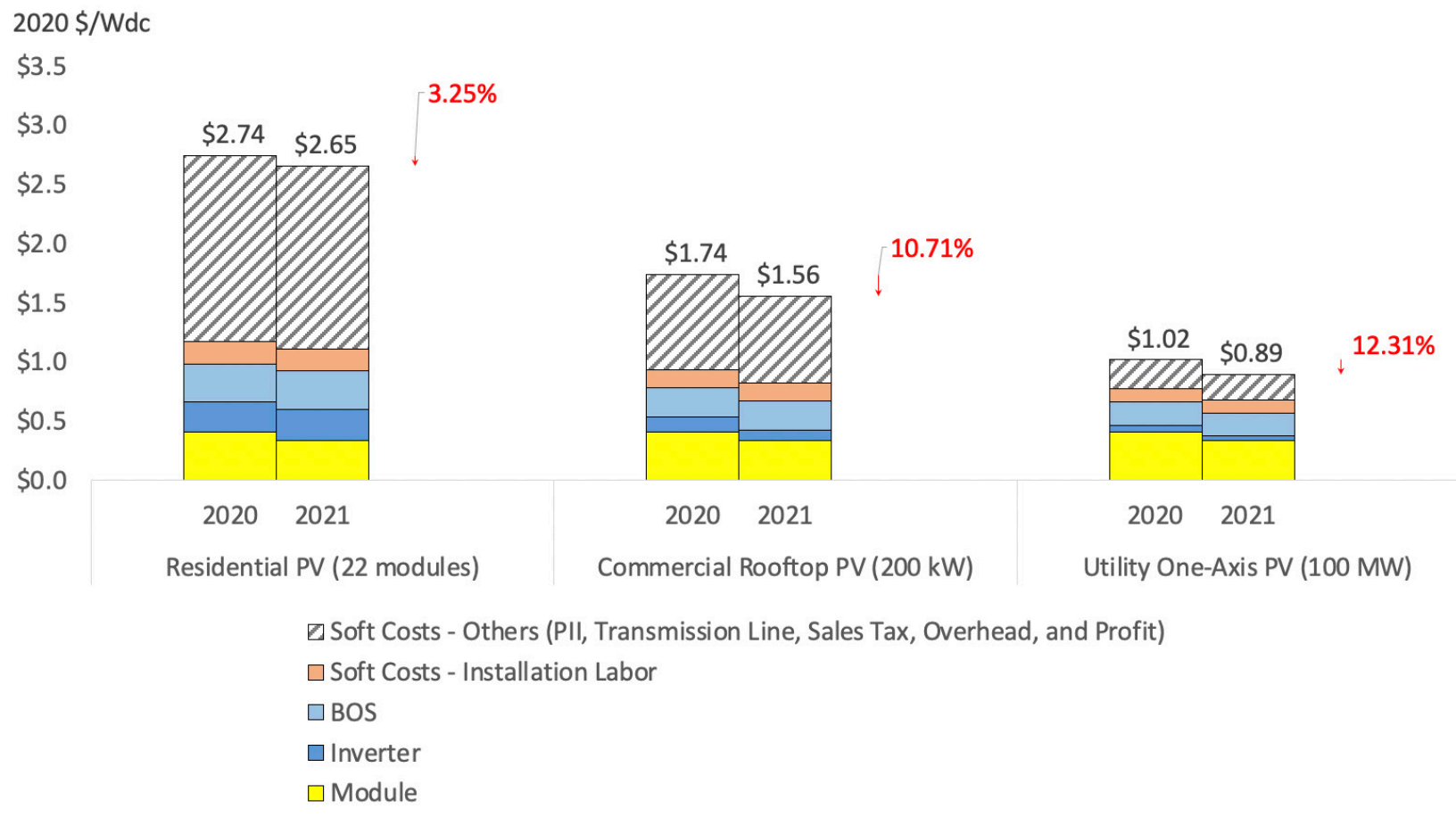

Figure ES-1. Comparison of Q1 2020 and Q1 2021 PV cost benchmarks

BOS is balance of system; PII is permitting, inspection, and interconnection.

Table ES-3. Comparison of Q1 2020 and Q1 2021 PV System Cost Benchmarks

\begin{tabular}{|l|l|l|l|}
\hline Sector & Residential PV & $\begin{array}{l}\text { Commercial } \\
\text { Rooftop PV }\end{array}$ & $\begin{array}{l}\text { Utility-Scale PV, } \\
\text { One-Axis Tracking }\end{array}$ \\
\hline $\begin{array}{l}\text { Q1 } 2020 \\
\text { benchmarks in } 2019 \\
\text { USD/WDC }\end{array}$ & $\$ 2.71$ & $\$ 1.72$ & $\$ 1.01$ \\
\hline $\begin{array}{l}\text { Q1 } 2021 \\
\text { Benchmarks in } \\
2020 \text { USD/WDC }\end{array}$ & $\$ 2.65$ & $\$ 1.56$ & $\$ 0.89$ \\
\hline $\begin{array}{l}\text { Drivers of cost } \\
\text { reduction }\end{array}$ & $\begin{array}{l}\text { Higher module efficiency } \\
\text { from 19.5\% to 19.9\%) } \\
\text { Lower module cost }\end{array}$ & $\begin{array}{l}\text { Higher module efficiency } \\
\text { Lower module cost }\end{array}$ & $\begin{array}{l}\text { Higher module efficiency } \\
\text { Lower module cost }\end{array}$ \\
\hline $\begin{array}{l}\text { Drivers of cost } \\
\text { increment }\end{array}$ & $\begin{array}{l}\text { Higher Inverter price } \\
\text { Higher labor wage } \\
\text { Higher material and } \\
\text { equipment cost }\end{array}$ & $\begin{array}{l}\text { Higher labor wage } \\
\text { Higher material and } \\
\text { equipment cost }\end{array}$ & $\begin{array}{l}\text { Higher labor wage } \\
\text { Higher steel price } \\
\text { Higher material and } \\
\text { equipment cost }\end{array}$ \\
\hline
\end{tabular}


Figure ES-2 shows the difference between Q1 2021 and Q1 2020 benchmark values adjusted for comparison. In addition to changing the dollar year from 2019 to 2020, we adjusted Q1 2020 values to have the same size storage capacity as the current Q1 2021 sizes to better demonstrate cost changes between years.

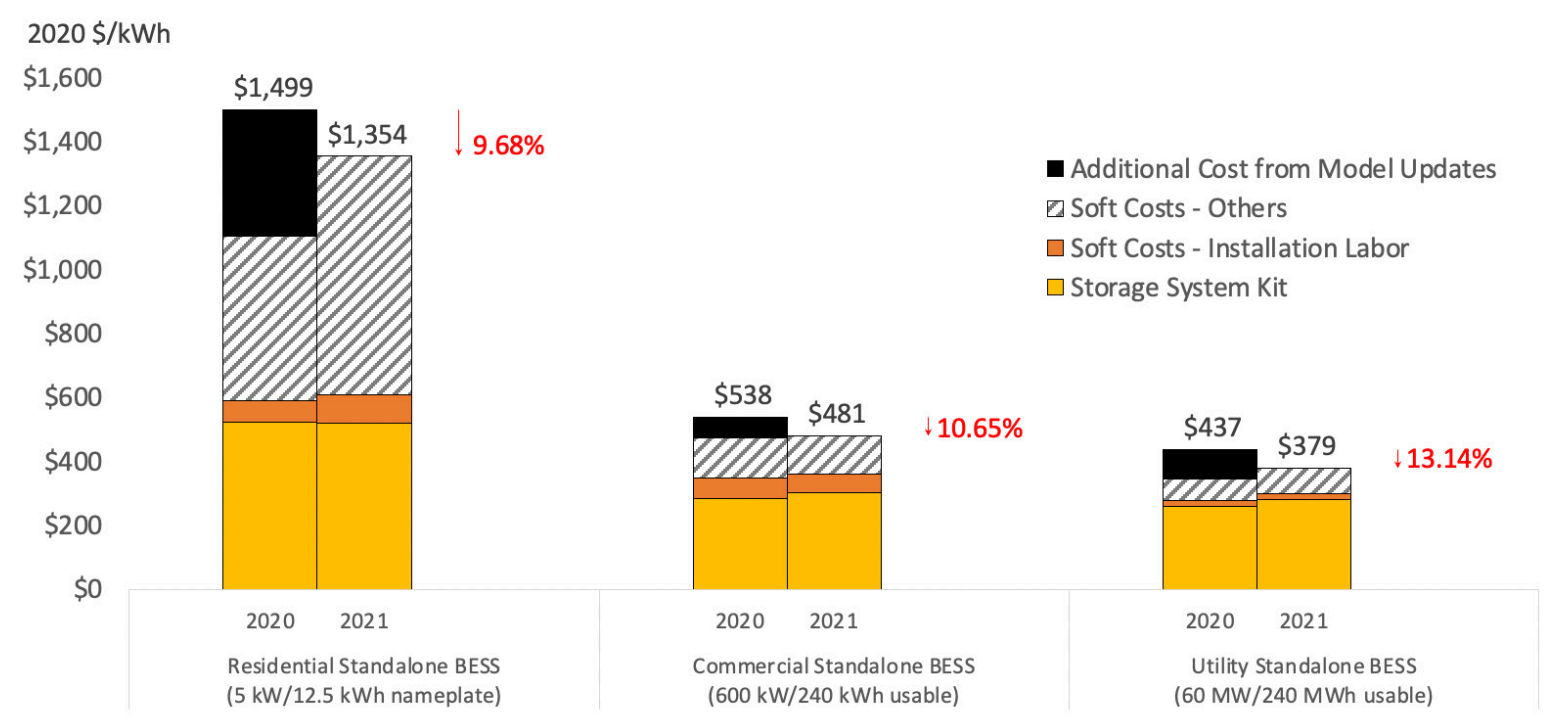

Figure ES-2. Comparison of Q1 2020 and Q1 2021 stand-alone BESS cost benchmarks

In previous benchmarking reports, across all sectors, storage system costs were represented in nameplate capacity but this year only the residential storage system cost is represented in nameplate capacity while commercial and utility scale storage system costs are represented in usable capacity. The Additional Cost from model updates category for Q1 2020 commercial and utility-scale systems represents the increase in cost that is due to adding storage capacity to keep the same values (600 kW/240 kWh, $60 \mathrm{MW} / 240 \mathrm{MWh}$ ) but is quoted in terms of usable capacity rather than nameplate capacity. Overbuilding battery capacity on the DC side is necessary to account for round-trip efficiency (RTE) loss and state of charge (SOC) limitations. The Q1 2020 residential storage capacity was also adjusted from previously benchmarked sizes of $5 \mathrm{~kW} / 20 \mathrm{kWh}$ and $3 \mathrm{~kW} / 6 \mathrm{kWh}$ to the Q1 2021 benchmarked sized of $5 \mathrm{~kW} / 12.5 \mathrm{kWh}$.

Figure ES-3 shows approximately $6 \%$ and 3\% reductions in residential PV-plus-storage benchmark between 2020 and 2021 for DC-coupled and AC-coupled cases respectively. Most of these reductions can be attributed to reductions in the cost of PV modules and battery packs. The cost reductions occurred despite the rated capacity of the 22-module system increasing from 7.0 $\mathrm{kW}$ to $7.15 \mathrm{~kW}$ between 2020 and 2021 . 


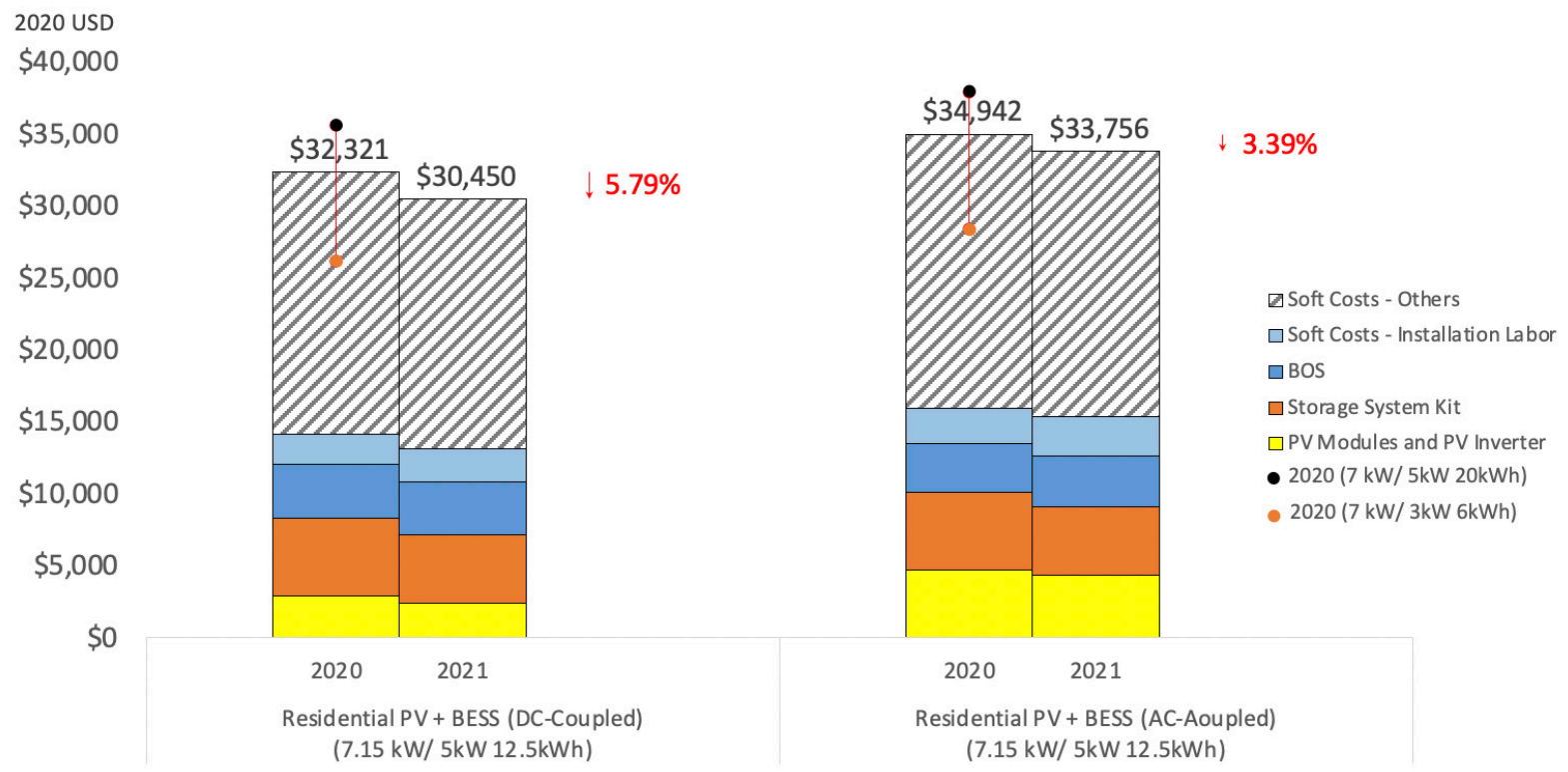

Figure ES-3. Comparison of Q1 2020 and Q1 2021 residential PV-plus-storage System Cost Benchmarks

The Q1 2020 residential storage capacity was adjusted from previously benchmarked sizes of $5 \mathrm{~kW} / 20 \mathrm{kWh}$ and $3 \mathrm{~kW} / 6 \mathrm{kWh}$ to the Q1 2021 benchmarked sized of $5 \mathrm{~kW} / 12.5 \mathrm{kWh}$. The cost of maximum power point tracking charge controllers is included in the BOS category.

Figure ES-4 shows the 9.3\% and 9.5\% reductions in commercial PV-plus-storage benchmark between 2020 and 2021 for DC-coupled and AC-coupled cases respectively. Figure ES-5 shows the $11.6 \%$ and $12.3 \%$ reductions in utility-scale PV-plus-storage benchmark between 2020 and 2021 for DC-coupled and AC-coupled cases respectively. Increased DC-DC converter cost in 2021 makes DC-coupled systems cost higher than AC-coupled systems.

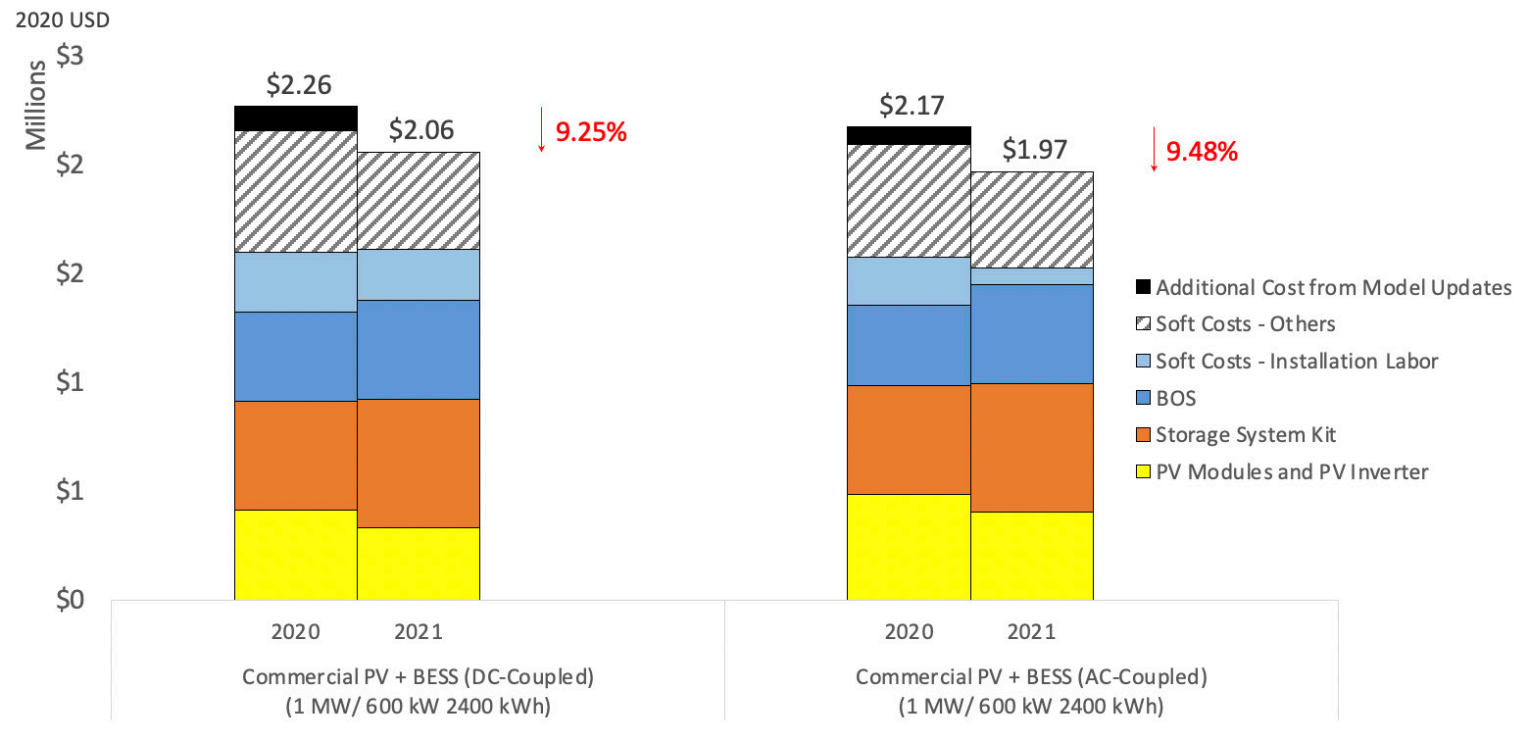

Figure ES-4. Comparison of Q1 2020 and Q1 2021 commercial PV plus-storage system cost benchmarks 
Commercial storage system costs before Q1 2021 were represented in nameplate capacity. The Additional Cost from model updates category for Q1 2020 commercial systems represents the increase in cost that is due to adding storage capacity to keep the same values (600 kW/240 kWh) but quoting in terms of usable rather than nameplate capacity with an overbuild factor of 1.3. Overbuilding battery capacity on the DC side is necessary to account for RTE loss (10\%) and state of charge limitations (20\%). Cost of system controls and communications, and DC-DC converter are included in the BOS cost category. When accounting for these changes and other model updates the storage system kit costs actually decreased between 2020 and 2021. Appendix A provides a detailed discussion of the changes made to the models between last year's versions (Feldman et al. 2021) and this year's versions.

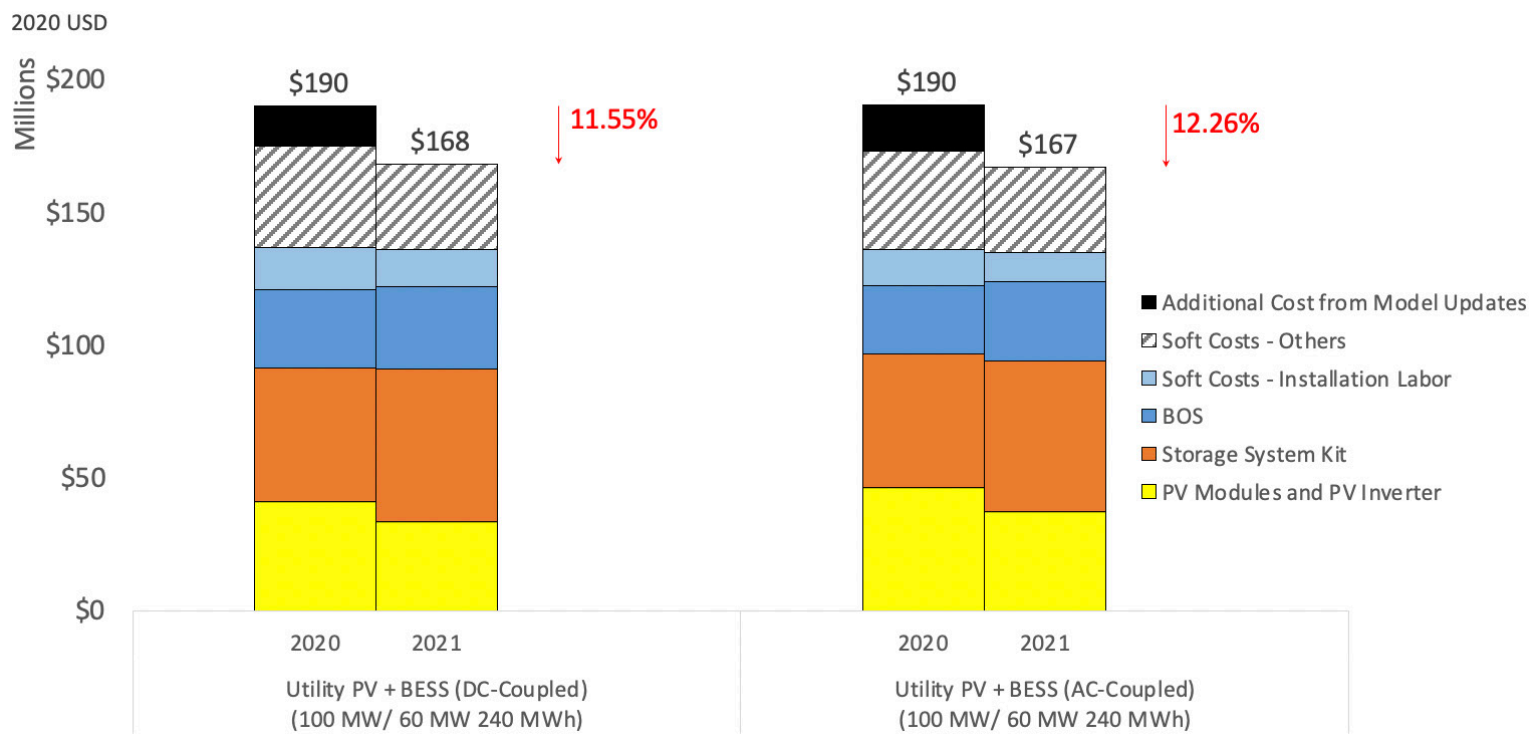

\section{Figure ES-5. Comparison of Q1 2020 and Q1 2021 utility-scale PV-plus-storage system cost benchmarks}

Utility-scale storage system costs before Q1 2021 were represented in nameplate capacity. The Additional Cost from model updates category for Q1 2020 utility-scale systems represents the increase in cost that is due to adding storage capacity to keep the same values (60 MW/240 MWh) but quoting in terms of usable rather than nameplate capacity with an overbuild factor of 1.3 . Overbuilding battery capacity on the DC side is necessary to account for RTE loss (10\%) and state of charge limitations (20\%). Cost of system controls and communications, and DC-DC converter are included in the BOS cost category. When accounting for these changes and other model updates the storage system kit costs actually decreased between 2020 and 2021. Appendix A provides a detailed discussion of the changes made to the models between last year's versions (Feldman et al. 2021) and this year's versions.

The changes in installed cost — along with changes in operation, system design, and technology - have resulted in changes in the levelized cost of energy (LCOE) (Figure ES-6). From 2020 to 2021, residential PV-plus-storage LCOE fell 13\%, ${ }^{4}$ and residential stand-alone-PV LCOE fell $9 \%$; there were $7 \%$ and $13 \%$ reductions in levelized electricity costs for commercial and utility-scale PV-plus-storage systems respectivley. At the same time, LCOE of commercial and utility scale PV systems fell by $9 \%$ and $12 \%$ respectively.

\footnotetext{
${ }^{4}$ Reported 2021 residential LCOE of PV plus storage system (LCOSS) values are 17\% higher than 2020 values because the 2021 report models a larger battery system $(5 \mathrm{~kW} ; 12.5 \mathrm{kWh})$ than the 2020 benchmark report $(3 \mathrm{~kW} /$ $12.5 \mathrm{kWh})$. When using 2020 LCOE of PV plus storage system model assumptions, the 2020 value rises from $20.1 \notin / \mathrm{kWh}$ to $21.5 \notin / \mathrm{kWh}$.
} 


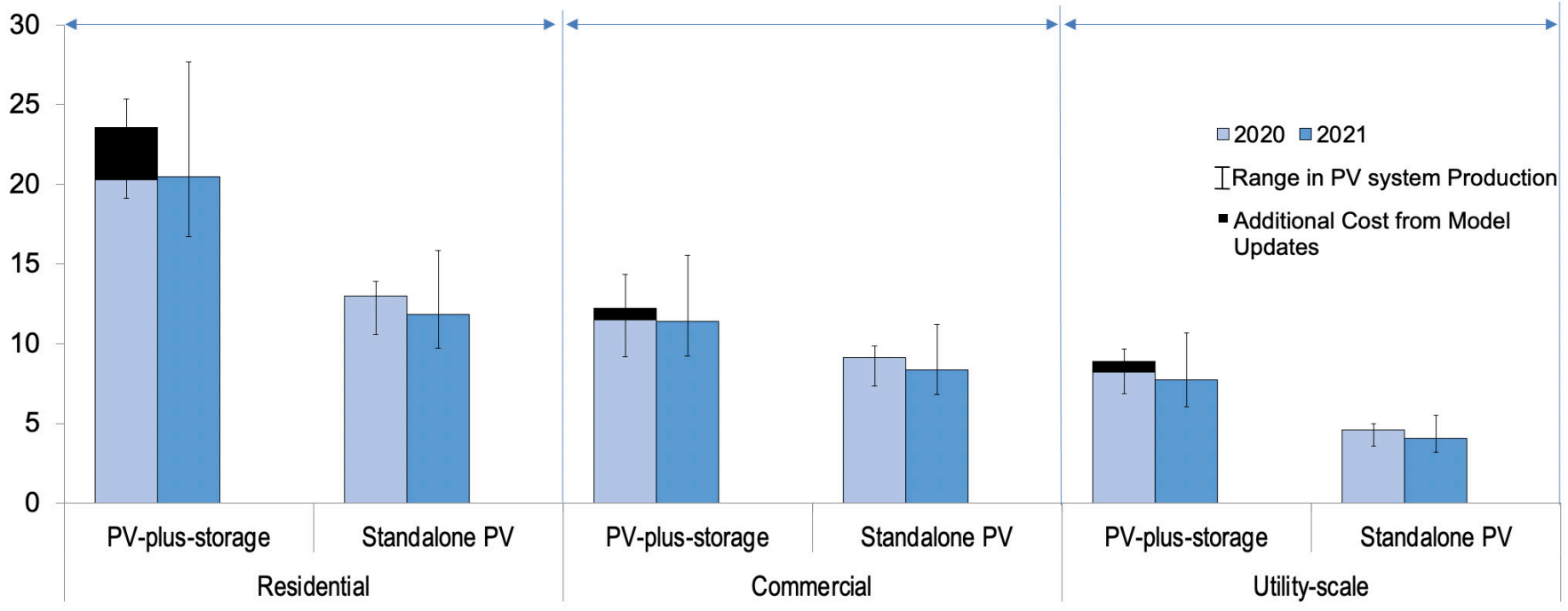

Figure ES-6. LCOE, 2020-2021

The current versions of our residential PV-plus-storage model assumes a battery size of $5 \mathrm{~kW} / 12.5 \mathrm{kWh}$; the Q1 2020 benchmark modeled a battery size of $3 \mathrm{~kW}$ (6 kWh) (Feldman et al. 2021). To better distinguish the historical cost trends from the changes to our cost models, we also calculate the Q1 2020 residential PV-plusstorage using a battery size of $5 \mathrm{kWh}(12.5 \mathrm{kWh})$. The Additional Costs from Model Updates category represents the difference between modeled results (3 kW/6 kWh: $20.1 \phi / \mathrm{kWh} ; 5 \mathrm{~kW} / 12.5 \mathrm{kWh}: 21.5 \phi / \mathrm{kWh})$. LCOE and LCOSS (levelized cost of solar-plus-storage) are calculated for each scenario under a range of capacity factors, but all other values remain the same. The locations used in the 2021 benchmarks for high and low solar resource level is the 2021 benchmarks are Daggett, California, and Seattle, Washington. The 2020 benchmarks used the more moderate locations of Phoenix, Arizona (High) and New York City, New York (Low), which explains the widened range of outcomes. Appendix A provides a detailed discussion of the changes made to the models between last year's versions (Feldman et al. 2021) and this year's versions. 


\section{Table of Contents}

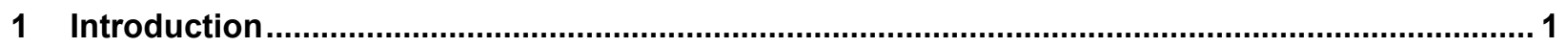

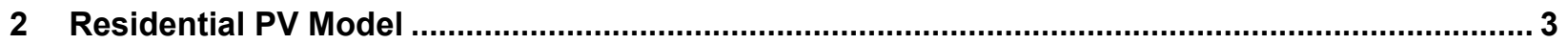

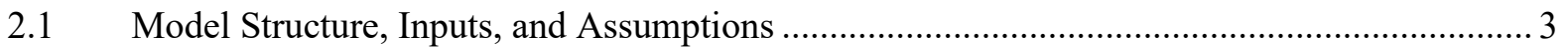

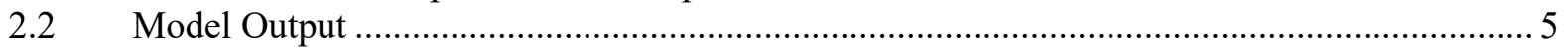

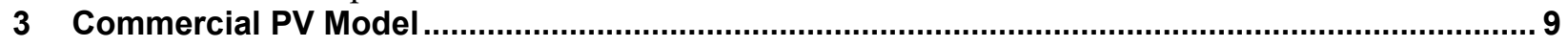

3.1 Model Structure, Inputs, and Assumptions …................................................................ 9

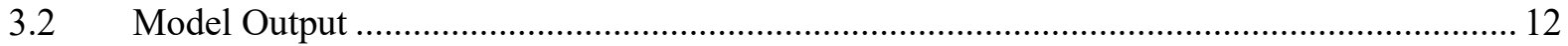

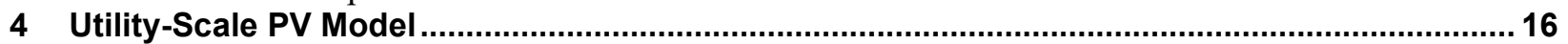

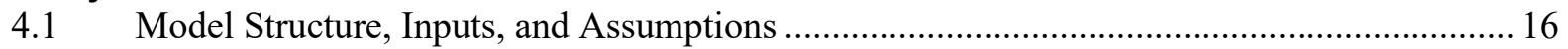

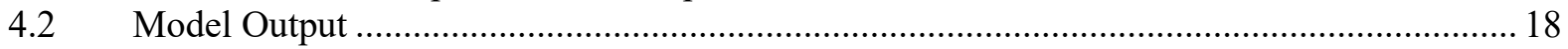

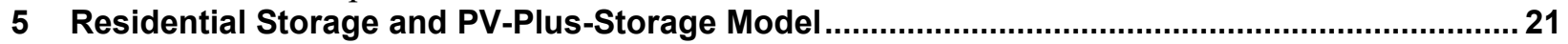

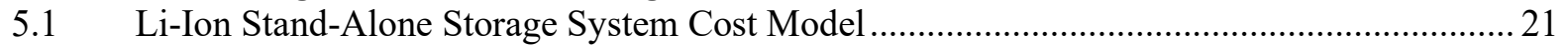

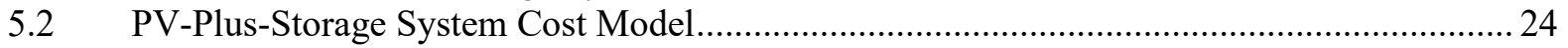

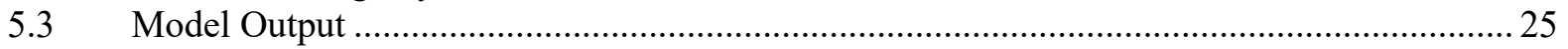

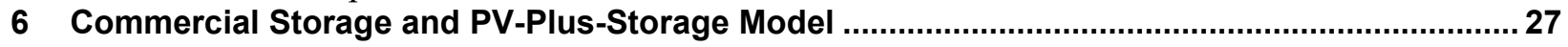

6.1 Li-Ion Stand-Alone Storage System Cost Model ................................................................ 27

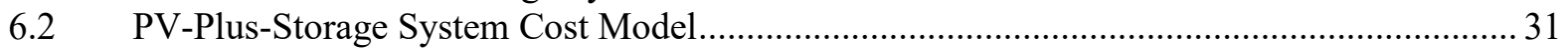

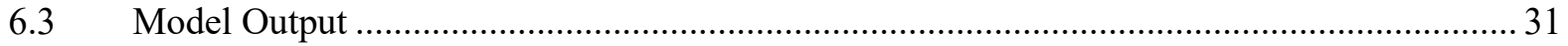

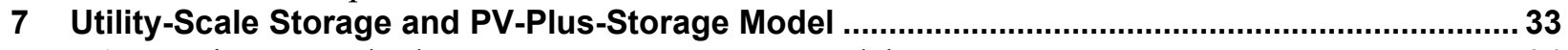

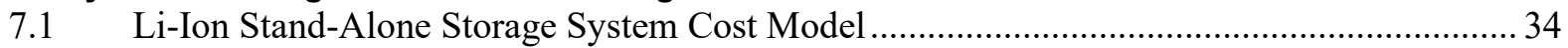

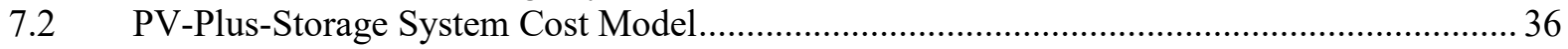

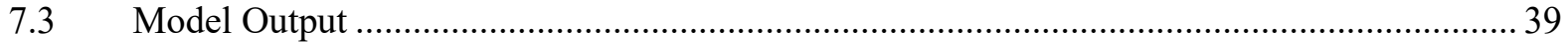

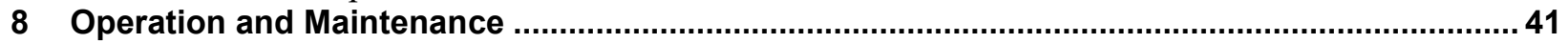

9 LCOE of Stand-Alone PV and PV-Plus-Storage Systems …..................................................4

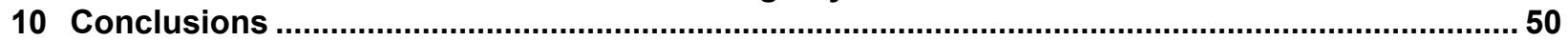

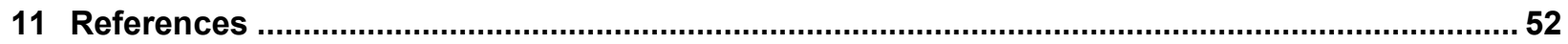

Appendix A. Changes in Methodology Between Q1 2020 and Q1 2021 Reports ............................ 55

Appendix B. PV System CAPEX and LCOE Benchmarks in 2020 USD ........................................59 


\section{List of Figures}

Figure ES-1. Comparison of Q1 2020 and Q1 2021 PV cost benchmarks..........................................vi

Figure ES-2. Comparison of Q1 2020 and Q1 2021 stand-alone BESS cost benchmarks...................vii

Figure ES-3. Comparison of Q1 2020 and Q1 2021 residential PV-plus-storage System

Cost Benchmarks................................................................................................................. vii

Figure ES-4. Comparison of Q1 2020 and Q1 2021 commercial PV plus-storage system

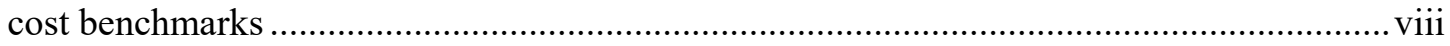

Figure ES-5. Comparison of Q1 2020 and Q1 2021 utility-scale PV-plus-storage system

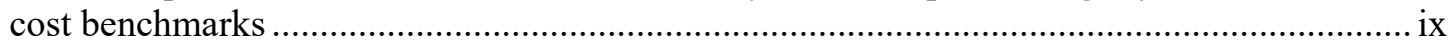

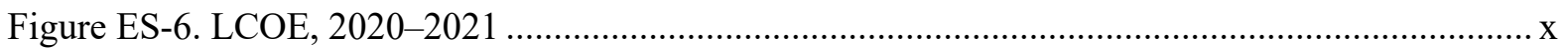

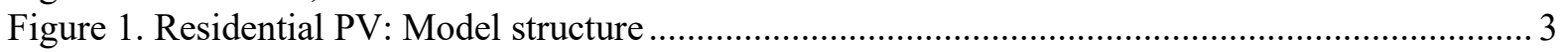

Figure 2. Q1 2021 U.S. benchmark: 7.15-kW residential PV system cost (2020 USD/W

Figure 3. Q1 2021 U.S. residential benchmark, by PV system size (2020 USD/W $\left.\mathrm{W}_{\text {DC }}\right)$........................ 7

Figure 4. Sensitivity analysis for the Q1 2021 benchmark: Mixed 7.15-kW residential system cost

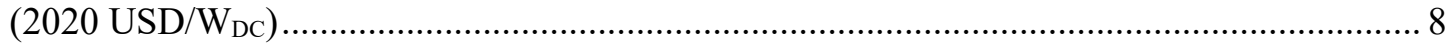

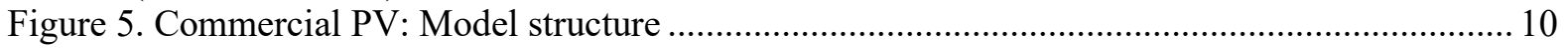

Figure 6. Q1 2021 U.S. benchmark: Commercial rooftop PV system cost (2020 USD/W DC)............ 13

Figure 7. Q1 2021 U.S. benchmark: Commercial ground-mounted PV system cost (2020 USD/W

Figure 8. Sensitivity analysis for the Q1 2021 benchmark: 200-kW rooftop commercial PV system cost $(2020$ USD/W

Figure 9. Sensitivity analysis for the Q1 2021 benchmark: 500-kW commercial ground-mounted PV

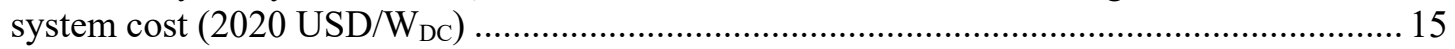

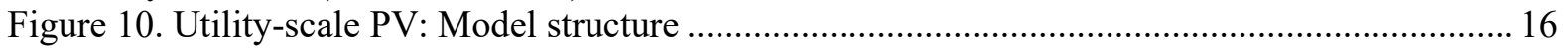

Figure 11. Q1 2021 U.S. benchmark: Utility-scale PV total cost (EPC + developer), 2020 USD/W $\mathrm{WC}_{\mathrm{DC}} 19$

Figure 12. Sensitivity analysis for the Q1 2021 benchmark: 100-MW one-axis utility-scale PV system cost (2020 USD/W

Figure 13. Installed cost of typical residential storage system only ............................................. 23

Figure 14. Installed cost of stand-alone residential storage system by size .................................... 24

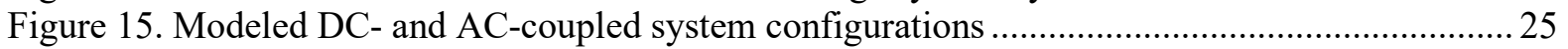

Figure 16. Modeled total installed cost and price components for residential PV-plus-storage systems,

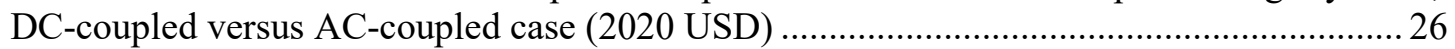

Figure 17. Traditional commercial and utility-scale Li-ion battery energy storage components ......... 27

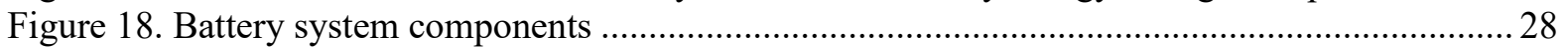

Figure 19. U.S. Commercial Li-Ion Battery Stand-Alone Storage Costs for Durations of 0.5-4.0

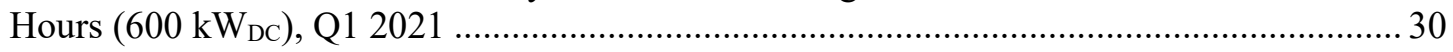

Figure 20. Cost benchmark for Commercial PV-plus-storage systems (4-hour duration) in different sites and the same site (DC-coupled and AC-coupled cases), Q1 2021 ................................. 32

Figure 21. Structure of the bottom-up cost model for utility-scale stand-alone storage systems ......... 33

Figure 22. U.S. utility-scale Li-ion battery stand-alone storage costs for durations of $0.5-4.0$ hours (60

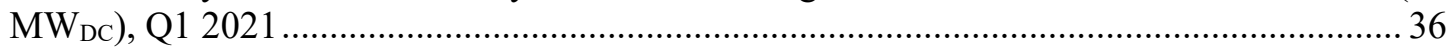

Figure 23. DC-coupled and AC-coupled PV-plus-storage system configurations ................................. 38

Figure 24. Cost benchmark for Utility PV-plus-storage systems (4-hour duration) in different sites and the same site (DC-coupled and AC-coupled cases), Q1 2021 ....................................... 40

Figure 25. Q1 2021 residential, commercial, and utility-scale O\&M costs by category.................... 43

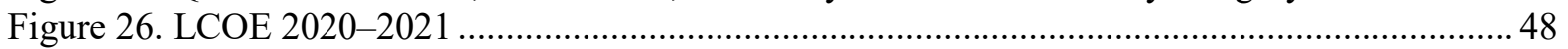

Figure 27. Comparison of Q1 2020 and Q1 2021 PV cost benchmarks............................................ 51

Figure 28. Comparison of Q1 2020 and Q1 2021 stand-alone BESS system cost benchmarks........... 51 


\section{List of Tables}

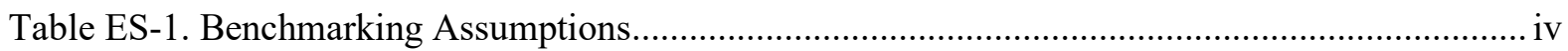

Table ES-2. Q1 2021 PV and Energy Storage Cost Benchmarks ..................................................

Table ES-3. Comparison of Q1 2020 and Q1 2021 PV System Cost Benchmarks..............................vi

Table 1. Residential PV: Modeling Inputs and Assumptions......................................................... 4

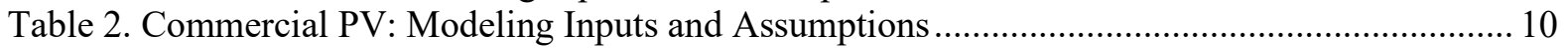

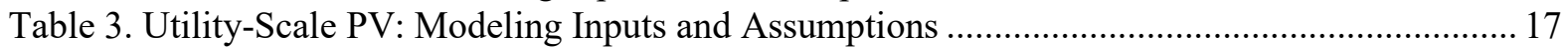

Table 4. Residential Storage-Only Modeling Inputs and Assumptions .......................................... 22

Table 5. Changes to Residential PV and Storage Models When PV and Storage Are Combined....... 25

Table 6. Commercial Li-ion Energy Storage System: Model Inputs and Assumptions..................... 28

Table 7. Changes to Commercial PV and Storage Models When PV and Storage Are Combined ..... 31

Table 8. Utility-Scale Li-ion Energy Storage System: Model Inputs and Assumptions ...................... 34

Table 9. Cost Factors for Siting PV and Storage Together versus Separately ................................... 37

Table 10. Comparison of DC- and AC-Coupling for Utility-Scale PV-plus-Storage Systems ............ 39

Table 11. LCOE (Stand-Alone PV) Input Assumptions and Outputs (2020 USD) ............................ 45

Table 12. LCOE (PV-plus-storage) Input Assumptions and Outputs (2020 USD)............................ 46

Table 13. Q1 2021 PV and Energy Storage Cost Benchmark....................................................... 50

Table A-1. Changes in Capacity Factor Methodology Between Q1 2020 and Q1 2021 Reports ........ 56

Table A-2. Changes in Residential PV LCOE Methodology Between Q1 2020 and Q1 2021 Reports56

Table A-3. Comparison of Q1 2020 Benchmark Costs, per Category, of Commercial and Utility PV

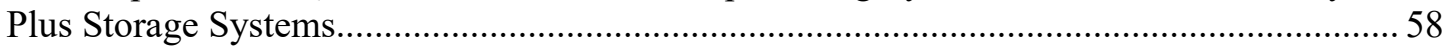

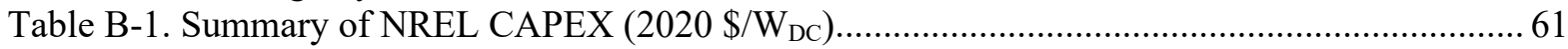

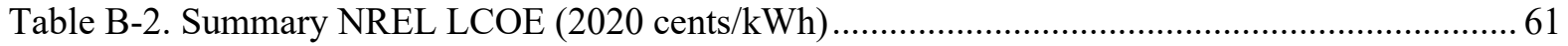




\section{Introduction}

This report continues previous tracking of photovoltaic (PV) cost reductions by benchmarking the costs of U.S. residential, commercial, and utility-scale PV, energy storage, and PV-plusstorage systems built in the first quarter (Q1) of 2021. ${ }^{5}$ It was produced in conjunction with several related research activities at the National Renewable Energy Laboratory (NREL) and Lawrence Berkeley National Laboratory, which are documented by Feldman et al. (2021); Barbose et al. (2020); Bolinger et al. (2020); ${ }^{6}$ Chung et al. (2015); Feldman et al. (2015); and Fu et al. (2016).

Our benchmarking method includes bottom-up accounting for all necessary system and projectdevelopment costs incurred when installing residential, commercial, and utility-scale systems, and it models the Q1 2021 costs for such systems excluding any previous supply agreements or contracts. In general, we attempt to model the typical installation techniques and business operations from an installed-cost perspective, and our benchmarks are national averages.

The benchmarking results may vary compared to system costs in other published reports for various reasons. For example, NREL's residential cost benchmark results do not include certain project-specific upgrade costs. Some of the most common upgrade activities include reroofing, main-panel upgrades, transformer upgrades, and additions of extra disconnect. Other reports may also quantify average or median reported prices or quotes over a particular period, which include data sets of systems with varying price markups, project timelines, project locations, system owners, and installers. All these factors can influence price and have a varying affect average or median prices, depending on how the composition of the data set changes each year. For example, in a given year if a larger percentage of systems are installed in higher-price markets than in the previous year, the benchmarking method will pull the average price up, irrespective of underlying cost and price trends; NREL's bottom-up cost modeling attempts to reduce this variability.

The residential PV-only benchmark and the commercial rooftop PV-only benchmark reflect average costs by inverter type (string inverters, string inverters with direct current [DC] optimizers, and microinverters), weighted by inverter market share. The residential PV-only benchmark is further averaged across small installer and national integrator business models, weighted by market share.

All benchmarks include variation - accounting for the differences in size, equipment, and operational use (particularly for storage) - that are currently available in the marketplace. All benchmarks assume nonunionized construction labor; residential and commercial PV systems

\footnotetext{
${ }^{5}$ Previous cost benchmark reports include reports published for Q1 2020 PV (Feldman et al. 2021), Q1 2018 PV (Fu, Feldman, and Margolis 2018), 2018 PV-plus-storage (Fu, Remo, and Margolis 2018), 2017 PV (Fu et al. 2017), 2016 PV (Fu et al. 2016), and 2015 utility-scale PV (Fu et al. 2015). All previous benchmarks can be found at NREL's "Solar Technology Cost Analysis" web page at www.nrel.gov/solar/solar-cost-analysis.html. Appendix B summarizes benchmark results for all previous NREL benchmark analyses (2010-2021).

${ }^{6}$ Lawrence Berkeley National Laboratory compares the bottom-up cost results of various entities, including our results.
} 
predominantly use nonunionized labor, and the type of labor required for utility-scale PV systems depends heavily on the development process. All benchmarks assume the use of monofacial monocrystalline silicon PV modules. Benchmarking using cadmium telluride or bifacial modules could result in significantly different results. ${ }^{7}$ The data in this annual benchmarking report inform the formulation of and track progress toward the U.S. Department of Energy (DOE) Solar Energy Technologies Office's Government Performance and Reporting Act cost targets.

Our modeled costs can be interpreted as the sales price an engineering, procurement, and construction (EPC) contractor or developer might charge for a system before any developer fee or price gross-up (although our costs do include development costs). We use this approach because of the wide variation in developer profits in all three sectors (residential, commercial, and utility-scale), where project pricing depends highly on region and project specifics such as local retail electricity rate structures, local rebate and incentive structures, competitive environment, and overall project or deal structures.

The current versions of our cost models make a few significant changes from the versions used in our previous Q1 2020 benchmarking report (Feldman et al. 2021). Appendix A provides a detailed discussion of the model updates from the previous benchmarking version, including the interconnection and transmission cost calculation, and the battery cabinet cost calculation.

The remainder of the report is organized as follows. Sections 2, 3, and 4 show specific model inputs and outputs for residential, commercial, and utility-scale PV-only systems. Sections 5, 6, and 7 show specific model inputs and outputs for residential, commercial, and utility-scale standalone storage systems and PV-plus-storage systems, including a limited set of historical trends in system costs and the levelized cost of PV-plus-storage. Section 8 provides specific levelized cost of energy (LCOE) and the levelized cost of PV-plus-storage model inputs and outputs for residential, commercial, and utility-scale PV and PV-plus-storage systems. Finally, Section 10 puts the results together and offers conclusions.

\footnotetext{
${ }^{7}$ In this report, we focus on the installation costs of crystalline-silicon modules, but a significant portion of U.S. utility-scale PV systems use cadmium telluride modules. From 2010 to 2020, cadmium telluride modules accounted for approximately $29 \%$ of U.S. utility-scale PV deployment (EIA 2021). This portion of the market is particularly noticeable given that cadmium telluride modules represented only $4 \%$ of global PV shipments over the same period. Similarly, a growing number of U.S. systems are beginning to use bifacial modules, with transparent backs, which generate electricity from both sides of the module - as opposed to traditional monofacial modules, which typically have opaque backsheets. Because of the newness of bifacial modules, we do not have sufficient data on their current U.S. market share.
} 


\section{Residential PV Model}

This section describes our residential PV model's structure, inputs, and assumptions (Section 2.1) and its output (Section 2.2).

\subsection{Model Structure, Inputs, and Assumptions}

We model a 7.15-kW residential rooftop system using 60-cell, monocrystalline, 19.9\%-efficient modules from a Tier 1 supplier (CA NEM 2021) and a standard flush-mounted, pitched-roof racking system. Figure 1 presents the cost drivers and assumptions, cost categories, inputs, and outputs of the model. Table 1 details the modeling inputs and assumptions.

\section{CORE COST \\ MODEL COST \\ DRIVERS

CATEGORIES \\ INPUTS \\ OUTPUTS}

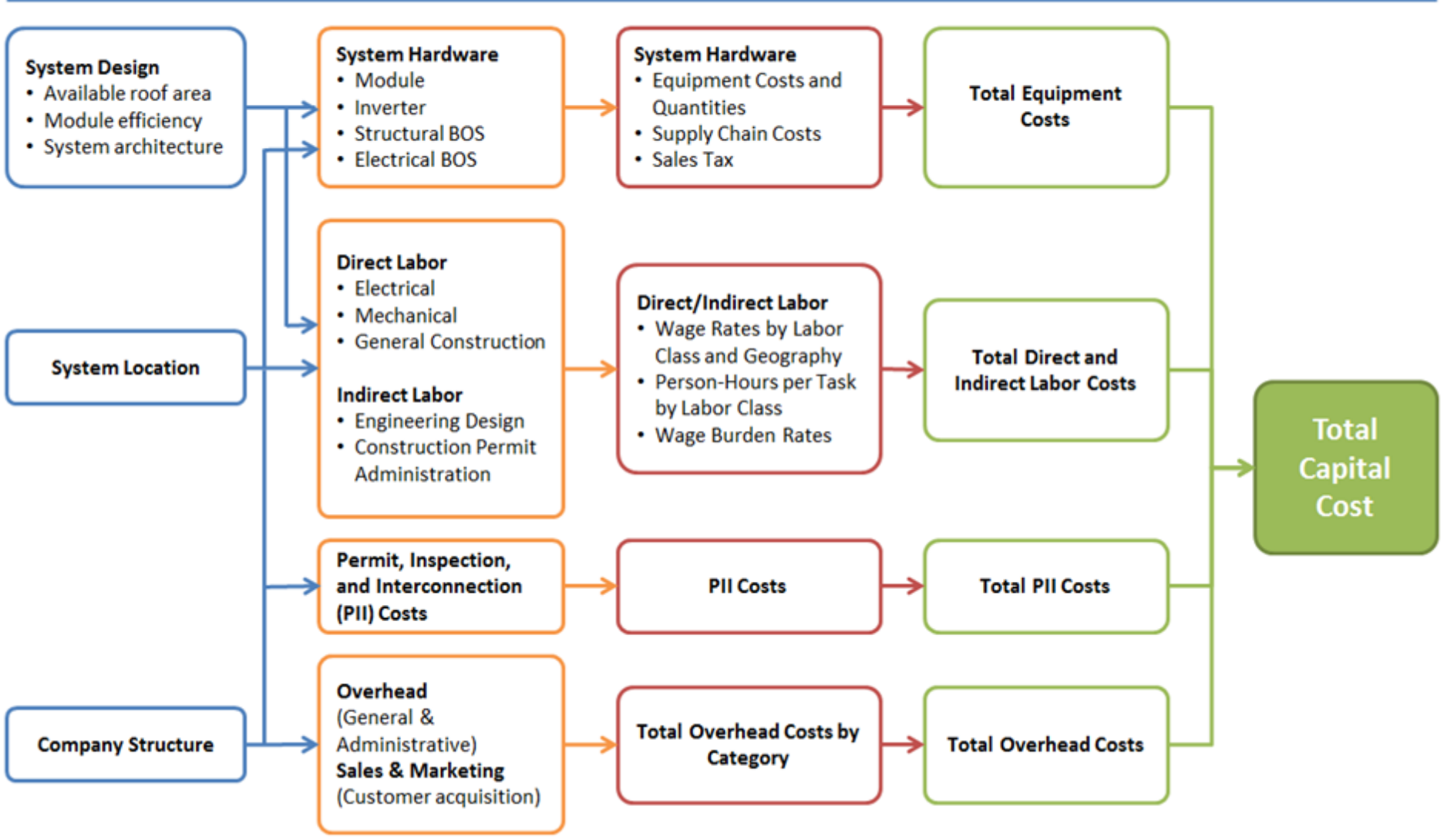

Figure 1. Residential PV: Model structure

$\mathrm{BOS}=$ balance of system 
Table 1. Residential PV: Modeling Inputs and Assumptions

\begin{tabular}{|c|c|c|c|}
\hline Category & Modeled Value & Description & Sources \\
\hline System size & $7.15 \mathrm{~kW}$ & $\begin{array}{l}\text { Average installed size per } \\
\text { system }\end{array}$ & $\begin{array}{l}\text { Barbose et al. 2020; } \\
\text { CA NEM } 2021\end{array}$ \\
\hline Module efficiency & $19.9 \%$ & Average module efficiency & CA NEM 2021 \\
\hline Module price & $\$ 0.34 / W_{D C}$ & $\begin{array}{l}\text { Ex-factory gate (first buyer) } \\
\text { price, Tier } 1 \text { monocrystalline } \\
\text { modules }\end{array}$ & $\begin{array}{l}\text { Wood Mackenzie } \\
\text { and SEIA } 2021\end{array}$ \\
\hline \multirow[t]{2}{*}{ Inverter price } & $\begin{array}{l}\text { Single-phase string } \\
\text { inverter: } \$ 0.15 / W_{D C}\end{array}$ & $\begin{array}{l}\text { Ex-factory gate (first buyer) } \\
\text { prices, Tier } 1 \text { inverters }\end{array}$ & \multirow{2}{*}{$\begin{array}{l}\text { Wood Mackenzie } \\
\text { 2021; Wood } \\
\text { Mackenzie and } \\
\text { SEIA } 2021\end{array}$} \\
\hline & $\begin{array}{l}\text { DC power optimizer } \\
\text { single-phase string } \\
\text { inverter: } \$ 0.28 / W_{D C} \\
\text { Microinverter: } \\
\$ 0.31 / W_{D C}\end{array}$ & & \\
\hline $\begin{array}{l}\text { Structural BOS } \\
\text { (racking) }\end{array}$ & $\$ 0.09 / W_{D C}$ & $\begin{array}{l}\text { Includes flashing for roof } \\
\text { penetrations and all rails and } \\
\text { clamps }\end{array}$ & NREL 2021 \\
\hline \multirow[t]{2}{*}{ Electrical BOS } & $\$ 0.19-\$ 0.30 / W_{D C}$ & \multirow[b]{2}{*}{$\begin{array}{l}\text { Conductors, switches, } \\
\text { combiners and transition } \\
\text { boxes, as well as conduit, } \\
\text { grounding equipment, } \\
\text { monitoring system or } \\
\text { production meters, fuses, } \\
\text { and breakers }\end{array}$} & \multirow{2}{*}{$\begin{array}{l}\text { Model assumptions, } \\
\text { NREL } 2021\end{array}$} \\
\hline & $\begin{array}{l}\text { Varies by inverter } \\
\text { option }\end{array}$ & & \\
\hline \multirow{4}{*}{$\begin{array}{l}\text { Supply chain } \\
\text { costs } \\
\text { (percentage of } \\
\text { equipment costs) }\end{array}$} & \multirow[t]{4}{*}{$\begin{array}{l}\text { Varies by installer } \\
\text { type and location }\end{array}$} & $\begin{array}{l}15 \% \text { costs and fees } \\
\text { associated with shipping and } \\
\text { handling of equipment }\end{array}$ & \multirow[t]{4}{*}{$\begin{array}{l}\text { NREL 2021; } \\
\text { model assumptions }\end{array}$} \\
\hline & & $\begin{array}{l}\text { Additional } 6 \% \text { cost for } \\
\text { historical inventory }\end{array}$ & \\
\hline & & $\begin{array}{l}\text { Additional } 20 \% \text { small-scale } \\
\text { procurement for module- } \\
\text { related supply chain costs for } \\
\text { small installers }\end{array}$ & \\
\hline & & $\begin{array}{l}\text { Additional } 20 \% \text { for inverter- } \\
\text { related supply chain costs for } \\
\text { small installers and } 10 \% \text { for } \\
\text { national integrators }\end{array}$ & \\
\hline Sales tax & $\begin{array}{l}\text { National average: } \\
5.1 \%\end{array}$ & $\begin{array}{l}\text { Sales tax on material } \\
\text { and equipment }\end{array}$ & RSMeans 2021 \\
\hline \multirow[t]{3}{*}{$\begin{array}{l}\text { Direct installation } \\
\text { labor }\end{array}$} & $\begin{array}{l}\text { Electrician: } \\
\$ 27.36 / \text { hour }\end{array}$ & \multirow[t]{3}{*}{$\begin{array}{l}\text { Modeled national average } \\
\text { labor rates }\end{array}$} & \multirow[t]{3}{*}{ BLS 2020; NREL 2021} \\
\hline & Laborer: \$18.22/hour & & \\
\hline & $\begin{array}{l}\text { Hours vary by } \\
\text { inverter option }\end{array}$ & & \\
\hline
\end{tabular}




\begin{tabular}{|c|c|c|c|}
\hline Category & Modeled Value & Description & Sources \\
\hline $\begin{array}{l}\text { Burden rates } \\
\text { (percentage of } \\
\text { direct labor) }\end{array}$ & $\begin{array}{l}\text { Total nationwide } \\
\text { average: } 31.7 \%\end{array}$ & $\begin{array}{l}\text { Workers' compensation, } \\
\text { federal and state } \\
\text { unemployment insurance, } \\
\text { Federal Insurance } \\
\text { Contributions Act, builder's } \\
\text { risk, and public liability }\end{array}$ & RSMeans 2021 \\
\hline \multirow{3}{*}{$\begin{array}{l}\text { Permitting, } \\
\text { inspection, and } \\
\text { interconnection } \\
\text { (PII) }\end{array}$} & $\begin{array}{l}\$ 0.21 / W_{D C} \text { for small } \\
\text { installers }\end{array}$ & \multirow{3}{*}{$\begin{array}{l}\text { Completed and submitted } \\
\text { applications, fees, design } \\
\text { changes, and field inspection }\end{array}$} & \multirow[t]{3}{*}{$\begin{array}{l}\text { NREL 2021; Cook et } \\
\text { al. } 2021\end{array}$} \\
\hline & $\begin{array}{l}\$ 0.23 / \mathrm{W}_{\mathrm{DC}} \text { for } \\
\text { national integrators }\end{array}$ & & \\
\hline & Varies by location & & \\
\hline \multirow{3}{*}{$\begin{array}{l}\text { Sales and } \\
\text { marketing } \\
\text { (customer } \\
\text { acquisition) }\end{array}$} & $\begin{array}{l}\$ 0.42 / \mathrm{W}_{\mathrm{DC}} \text { (small } \\
\text { installer) }\end{array}$ & \multirow{3}{*}{$\begin{array}{l}\text { Initial and final drawing plans, } \\
\text { advertising, lead generation, } \\
\text { sales pitch, contract } \\
\text { negotiation, and customer } \\
\text { interfacing }\end{array}$} & \multirow[t]{3}{*}{ NREL 2021} \\
\hline & $\begin{array}{l}\$ 0.58 / \mathrm{WDC}_{\mathrm{DC}} \text { (national } \\
\text { integrator) }\end{array}$ & & \\
\hline & Varies by location & & \\
\hline \multirow{3}{*}{$\begin{array}{l}\text { Overhead } \\
\text { (general and } \\
\text { administrative) }\end{array}$} & $\begin{array}{l}\$ 0.27 / \mathrm{W}_{\mathrm{DC}} \text { (small } \\
\text { installer) }\end{array}$ & \multirow{3}{*}{$\begin{array}{l}\text { Rent, building, equipment, } \\
\text { staff expenses not directly } \\
\text { tied to PII, customer } \\
\text { acquisition, or direct } \\
\text { installation labor }\end{array}$} & \multirow[t]{3}{*}{ NREL 2021} \\
\hline & $\begin{array}{l}\$ 0.28 / W_{D C} \text { (national } \\
\text { integrator) }\end{array}$ & & \\
\hline & Varies by location & & \\
\hline Profit (\%) & $17 \%$ & $\begin{array}{l}\text { Fixed percentage margin } \\
\text { applied to all direct } \\
\text { costs including hardware, } \\
\text { installation labor, direct sales } \\
\text { and marketing, design, } \\
\text { installation, and permitting } \\
\text { fees }\end{array}$ & Fu et al. 2017 \\
\hline
\end{tabular}

\subsection{Model Output}

Figure 2 (page 6) presents the U.S. national benchmark from our residential PV model. Market shares of $63 \%$ for small installers and $37 \%$ for national integrators (Barbose et al. 2020) are used to compute the national weighted average. String inverter, power optimizer, and microinverter options are each modeled individually, and the mixed case applies their market shares (13\%, $54 \%$, and 33\%) as weightings (Barbose et al. 2020).

Figure 3 (page 7) presents the U.S. national benchmark from our residential PV models, for a range of typical sizes. We model different system sizes because of (1) the variety in residential PV system sizes in the marketplace and (2) the strong relationship between size and cost, on a per-watt basis. Economies of scale — driven by hardware, labor, and related markups - are evident here, as is the impact of costs spread over a larger number of watts. Figure 3 shows a soft cost reduction of $62 \%$ between a $3-\mathrm{kW}$ and an $11-\mathrm{kW}$ system. Hence, as system sizes increase, the per-watt cost to build systems decreases. 


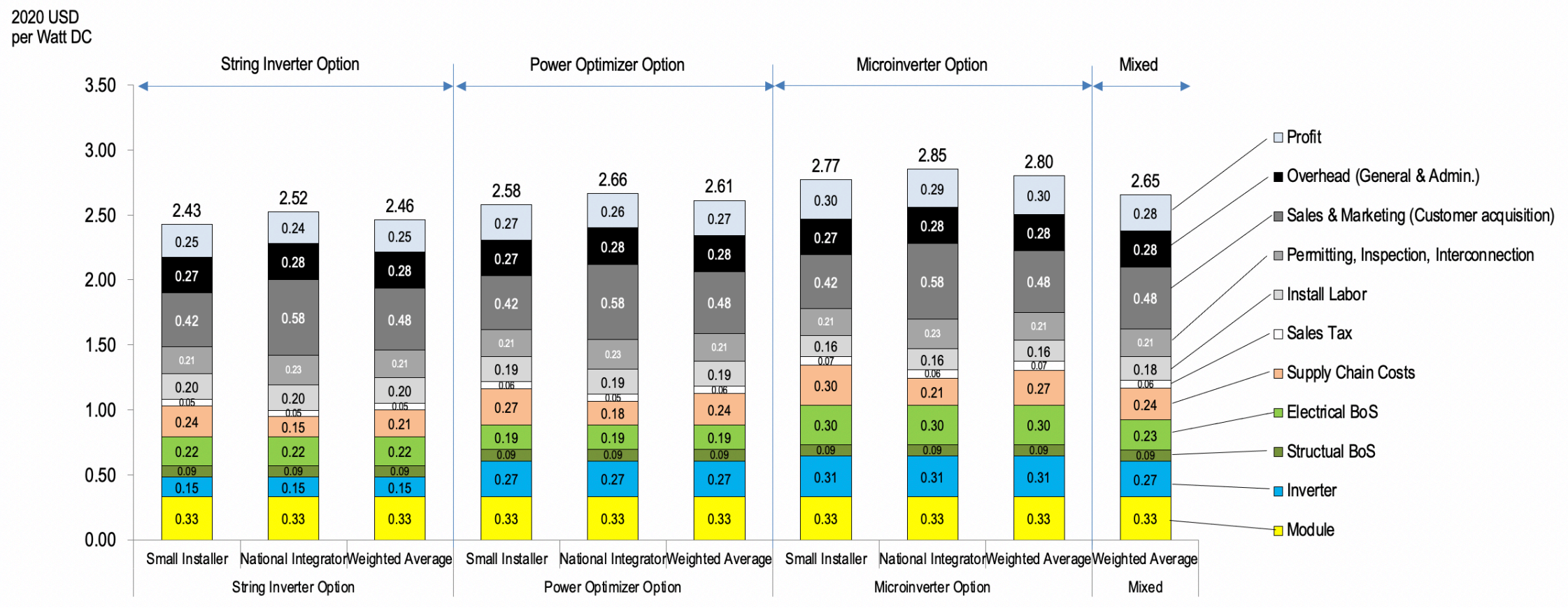

Figure 2. Q1 2021 U.S. benchmark: 7.15-kW residential PV system cost (2020 USD/WDC) 


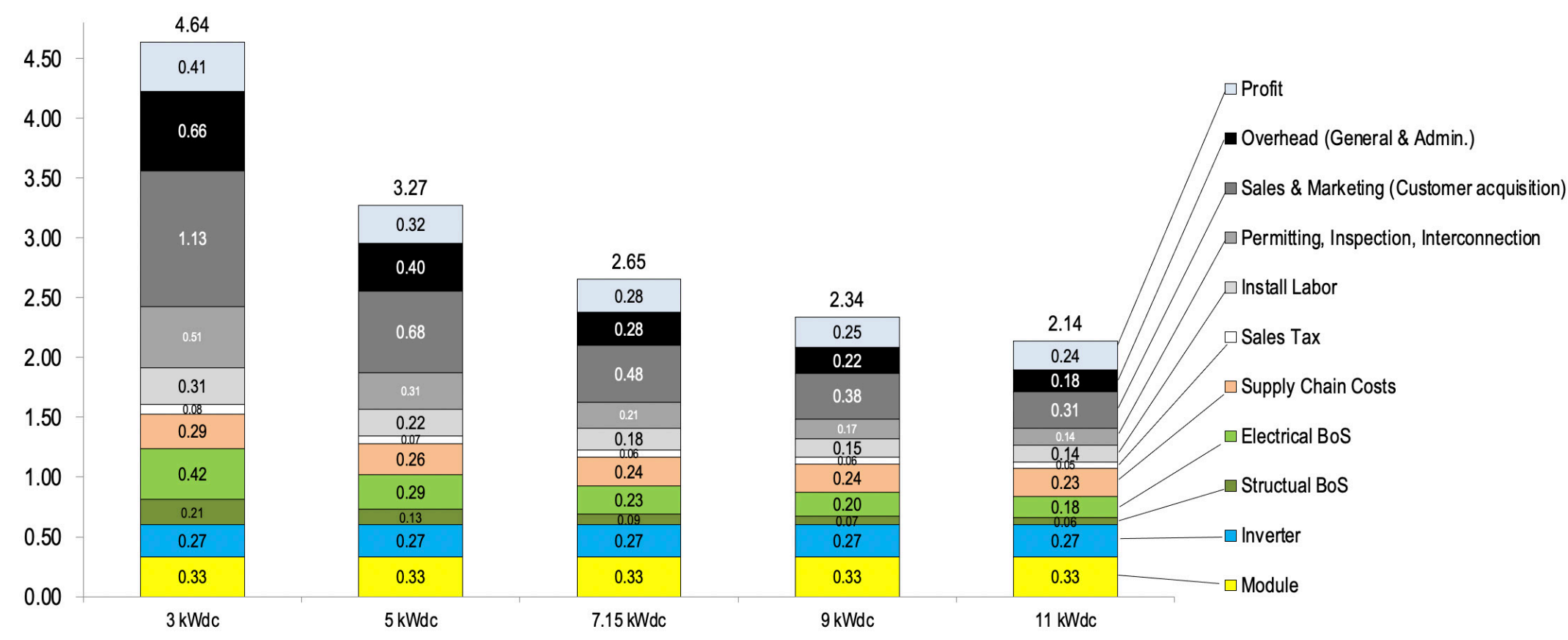

Figure 3. Q1 2021 U.S. residential benchmark, by PV system size (2020 USD/WDC) 
Figure 4 (page 8) shows a sensitivity analysis for the mixed case, with cost categories that vary by location and hardware specification. Inverter type has the largest impact on installed system cost, with use of string inverters resulting in $\$ 2.46 / \mathrm{W}_{\mathrm{DC}}$ and use of microinverters resulting in $\$ 2.80 / \mathrm{W}_{\mathrm{DC}}$.

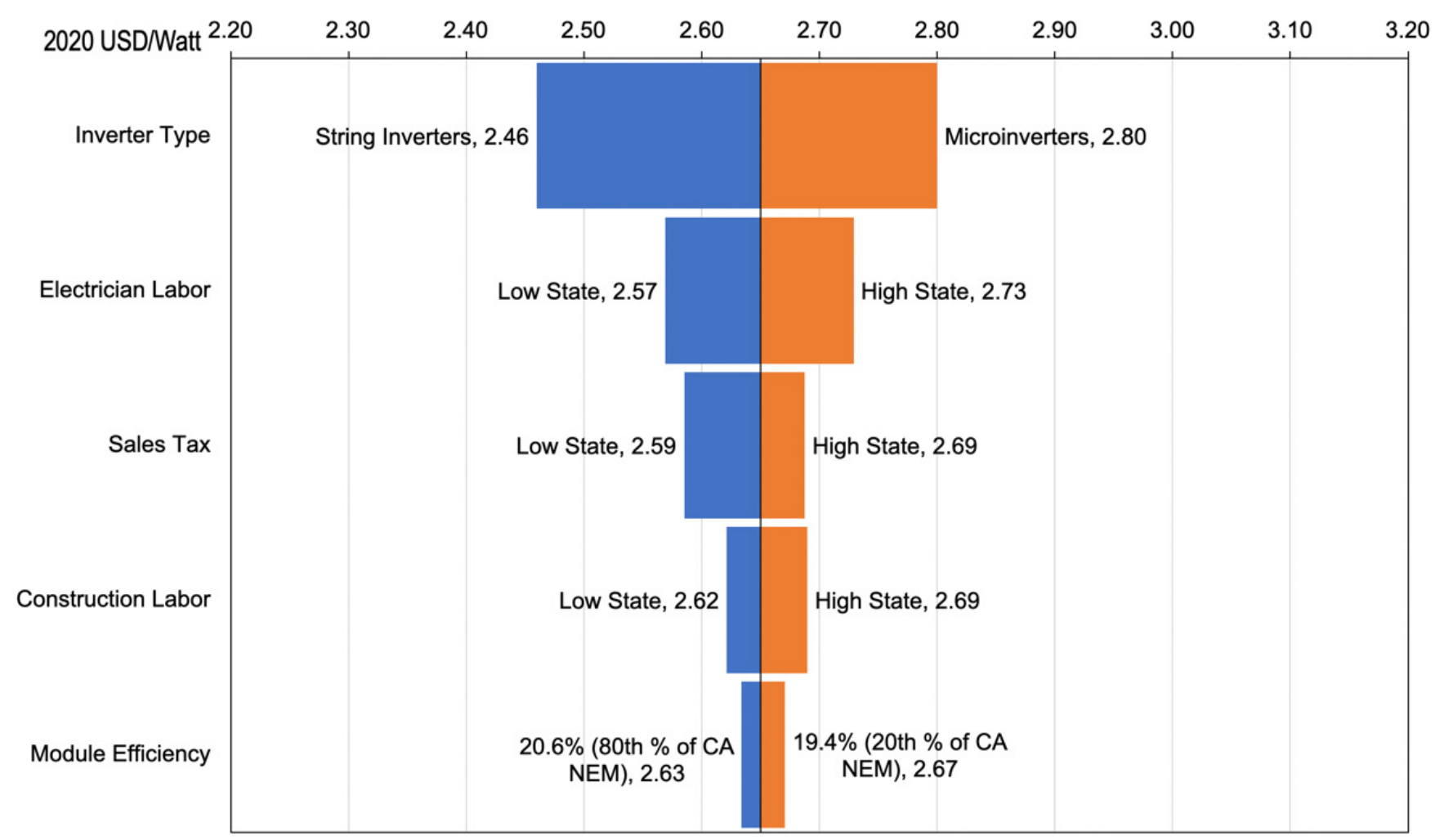

Figure 4. Sensitivity analysis for the Q1 2021 benchmark: Mixed 7.15-kW residential system cost (2020 USD/W 


\section{Commercial PV Model}

This section describes our commercial PV model's structure, inputs, and assumptions (Section 3.1) and its output (Section 3.2).

\subsection{Model Structure, Inputs, and Assumptions}

We model both a 200-kW, 1,000-volt DC ( $\left.\mathrm{V}_{\mathrm{DC}}\right)$, commercial-scale flat-roof system using a ballasted racking solution on a membrane roof $^{8}$ and a $500-\mathrm{kW}, 1,000-\mathrm{V}_{\mathrm{DC}}$ commercial-scale fixed-tilt ground-mounted system using driven-pile foundations; the ground-mounted system is larger because U.S. ground-mounted systems are larger than rooftop systems on average. Because many states have adopted the 2017 and 2020 National Electrical Code, we model threephase string inverter, power optimizer, and microinverter options individually for the commercial rooftop model, and the mixed case applies their market shares $(76 \%, 20 \%$, and $4 \%$ respectively) as weightings (Barbose et al. 2020). Because the 2017 National Electrical Code only requires rapid shutdown at the module level for rooftop applications, the commercial ground-mounted system models only three-phase string inverters. Both models use monocrystalline 19.9\%-efficient modules from a Tier 1 supplier (CA NEM 2021).

We also model a range of system sizes, from $100 \mathrm{~kW}$ to $2 \mathrm{MW}$. Figure 5 is a schematic of our commercial-scale system cost model, and Table 2 details the modeling inputs and assumptions. We separate our cost estimate into EPC and project-development functions. Although some firms engage in both activities in an integrated manner, and potentially achieve lower cost and pricing by reducing the total margin across functions, we believe the distinction can help separate and highlight the specific cost trends and drivers associated with each function.

\footnotetext{
${ }^{8}$ A penetrating PV mounting system can have higher energy yield $(\mathrm{kWh} / \mathrm{kW})$ than a ballasted racking solution because of the wider tilt-angle range allowance. However, we do not model this system type, because its market share has declined as a result of the additional flashing and sealing work required, roof warranty issues, and the difficulty of replacing such systems.
} 


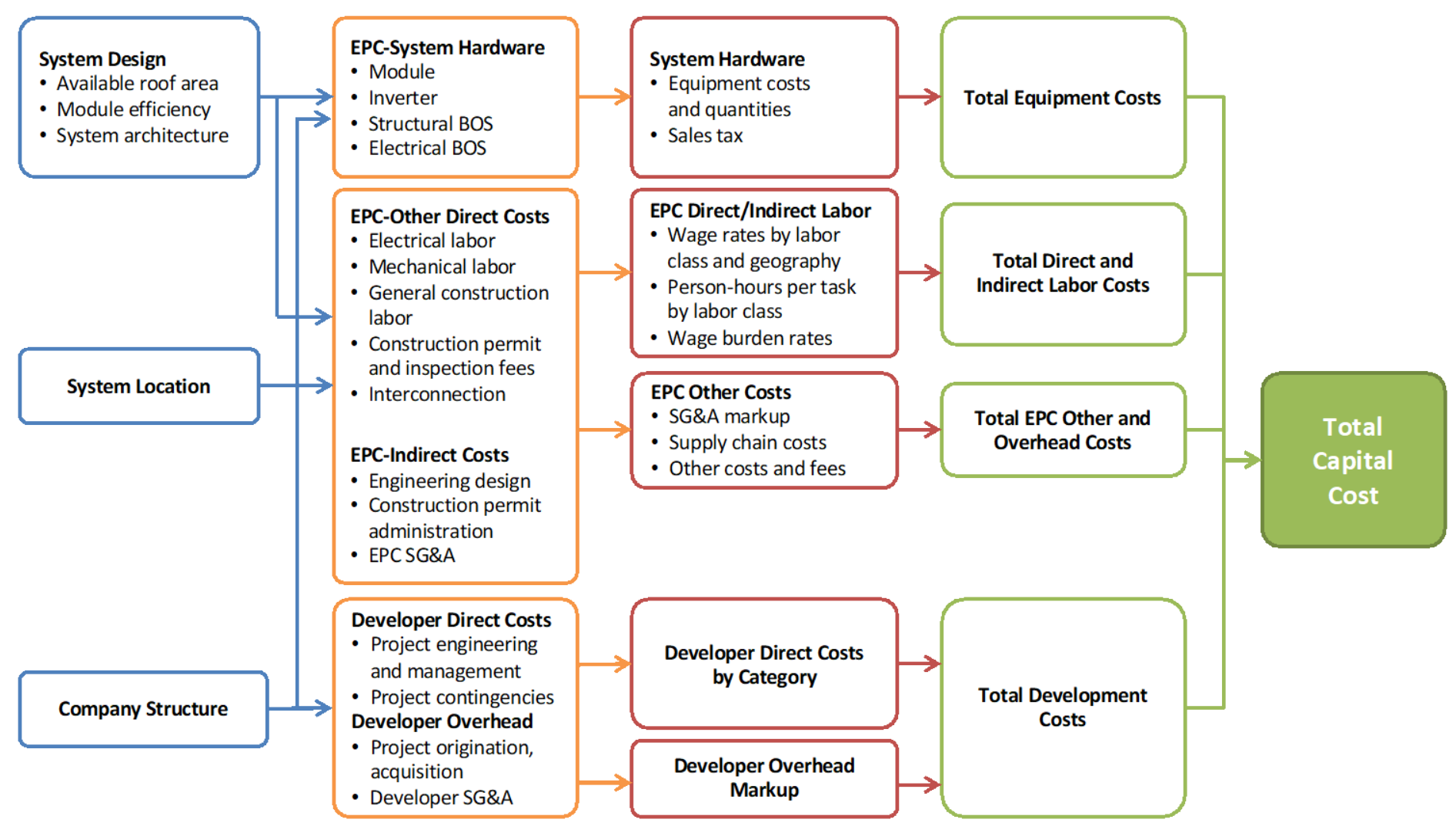

Figure 5. Commercial PV: Model structure

SG\&A = selling, general, and administrative

Table 2. Commercial PV: Modeling Inputs and Assumptions

\begin{tabular}{llll}
\hline Category & Modeled Value & Description & Sources \\
\hline System size & $\begin{array}{l}200 \mathrm{~kW}(\text { rooftop) and } \\
500 \mathrm{~kW}(\text { ground-mount); } \\
\text { range }(100 \mathrm{~kW}-2 \mathrm{MW})\end{array}$ & $\begin{array}{l}\text { Average installed size } \\
\text { per system }\end{array}$ & Barbose et al. 2020 \\
\hline $\begin{array}{l}\text { Module } \\
\text { efficiency }\end{array}$ & $19.9 \%$ & $\begin{array}{l}\text { Average monocrystalline } \\
\text { module efficiency }\end{array}$ & CA NEM 2021 \\
\hline Module price & $\$ 0.34 / \mathrm{WDC}_{\mathrm{DC}}$ & $\begin{array}{l}\text { Ex-factory gate (first } \\
\text { buyer) average selling } \\
\text { price, Tier 1 } \\
\text { monocrystalline modules }\end{array}$ & $\begin{array}{l}\text { Wood Mackenzie } \\
\text { and SEIA 2021 }\end{array}$ \\
\hline
\end{tabular}




\begin{tabular}{|c|c|c|c|}
\hline Category & Modeled Value & Description & Sources \\
\hline \multirow[t]{3}{*}{ Inverter price } & $\begin{array}{l}\text { Three-phase string } \\
\text { inverter: } \$ 0.08 / \mathrm{W}_{\mathrm{DC}}\end{array}$ & \multirow{3}{*}{$\begin{array}{l}\text { Ex-factory gate prices } \\
\text { (first buyer) average } \\
\text { selling price, Tier } 1 \\
\text { inverters }\end{array}$} & \multirow[t]{3}{*}{$\begin{array}{l}\text { Wood Mackenzie 2021; Wood } \\
\text { Mackenzie and SEIA } 2021\end{array}$} \\
\hline & $\begin{array}{l}\text { DC power optimizer } \\
\text { three-phase string } \\
\text { inverter: } \$ 0.16 / \mathrm{WDC}_{\mathrm{DC}} \\
\text { (rooftop only) }\end{array}$ & & \\
\hline & $\begin{array}{l}\text { Microinverter: } \$ 0.31 / \mathrm{W}_{D C} \\
\text { (rooftop only) }\end{array}$ & & \\
\hline $\begin{array}{l}\text { Structural } \\
\text { components } \\
\text { (racking) }\end{array}$ & $\begin{array}{l}\$ 0.11-\$ 0.18 / \mathrm{W}_{\mathrm{DC}} ; \\
\text { assumes national } \\
\text { average wind and snow } \\
\text { loading }{ }^{\mathrm{a}} \text {; varies by } \\
\text { racking type (ground- } \\
\text { mounted versus rooftop- } \\
\text { ballasted) }\end{array}$ & $\begin{array}{l}\text { Ex-factory gate prices; } \\
\text { flat-roof ballasted racking } \\
\text { system or fixed-tilt } \\
\text { ground-mounted racking } \\
\text { system }\end{array}$ & $\begin{array}{l}\text { MEPS 2019; } \\
\text { model assumptions; } \\
\text { NREL } 2021\end{array}$ \\
\hline $\begin{array}{l}\text { Electrical } \\
\text { components }\end{array}$ & $\$ 0.13-\$ 0.45 / \mathrm{W}_{\mathrm{DC}}$ & $\begin{array}{l}\text { Conductors, conduit and } \\
\text { fittings, transition boxes, } \\
\text { switchgear, panel boards, } \\
\text { and other parts }\end{array}$ & $\begin{array}{l}\text { Model assumptions; } \\
\text { NREL 2021; RSMeans } 2021\end{array}$ \\
\hline $\begin{array}{l}\text { EPC } \\
\text { overhead } \\
\text { (percentage of } \\
\text { equipment } \\
\text { costs) }\end{array}$ & $13 \%$ & $\begin{array}{l}\text { Costs and fees } \\
\text { associated with EPC } \\
\text { overhead, inventory, } \\
\text { shipping, and handling }\end{array}$ & NREL 2021 \\
\hline Sales tax & National average: $5.1 \%$ & $\begin{array}{l}\text { Sales tax on equipment } \\
\text { costs }\end{array}$ & RSMeans 2021 \\
\hline $\begin{array}{l}\text { Direct } \\
\text { installation } \\
\text { labor }\end{array}$ & $\begin{array}{l}\text { Electrician: } \$ 27.36 / \text { hour } \\
\text { Laborer: } \$ 18.22 / \text { hour }\end{array}$ & $\begin{array}{l}\text { Modeled labor rate } \\
\text { assumes national } \\
\text { average nonunionized } \\
\text { labor rates }\end{array}$ & BLS 2020; NREL 2021 \\
\hline $\begin{array}{l}\text { Burden rates } \\
\text { (percentage of } \\
\text { direct labor) }\end{array}$ & $\begin{array}{l}\text { Total nationwide } \\
\text { average: } 31.7 \%\end{array}$ & $\begin{array}{l}\text { Workers' compensation, } \\
\text { federal and state } \\
\text { unemployment insurance, } \\
\text { Federal Insurance } \\
\text { Contributions Act, } \\
\text { builders' risk, public } \\
\text { liability }\end{array}$ & RSMeans 2021 \\
\hline PII & $\$ 0.03-\$ 0.12 / W_{D C}$ & $\begin{array}{l}\text { For construction permits } \\
\text { fee, interconnection study } \\
\text { fees for existing } \\
\text { substation, testing, and } \\
\text { commissioning }\end{array}$ & NREL 2021 \\
\hline
\end{tabular}




\begin{tabular}{|c|c|c|c|}
\hline Category & Modeled Value & Description & Sources \\
\hline $\begin{array}{l}\text { Developer } \\
\text { overhead }\end{array}$ & $\begin{array}{l}\$ 0.27-\$ 0.47 / \mathrm{W} \\
\text { Varies by system size } \\
\text { ( } 30 \% \text { developer } \\
\text { overhead) }\end{array}$ & $\begin{array}{l}\text { Includes overhead } \\
\text { expenses such as payroll, } \\
\text { facilities, travel, legal } \\
\text { fees, administrative, } \\
\text { business development, } \\
\text { finance, and other } \\
\text { corporate functions }\end{array}$ & $\begin{array}{l}\text { Model assumptions; } \\
\text { NREL } 2021\end{array}$ \\
\hline Contingency & $4 \%$ & $\begin{array}{l}\text { Estimated as markup on } \\
\text { EPC cost; value } \\
\text { represents actual cost } \\
\text { overruns above estimated } \\
\text { cost }\end{array}$ & NREL 2021 \\
\hline Profit & $7 \%$ & $\begin{array}{l}\text { Applies a fixed } \\
\text { percentage margin to all } \\
\text { costs, including } \\
\text { hardware, installation } \\
\text { labor, EPC overhead, and } \\
\text { developer overhead }\end{array}$ & NREL 2021 \\
\hline
\end{tabular}

${ }^{a}$ Racking companies currently meet the national standard, so there is not as much differentiation by state in the market within rooftop systems. The ground-mounted racking system requires more material, equipment, and labor than the ballasted racking system. However, installation of ground-mounted PV systems at utility scale helps reduce the BOS cost of these systems because of economies of scale.

\subsection{Model Output}

Between 2020 and 2021, there were 10.7\% $(\$ 0.19 / \mathrm{W})$ and $6.0 \%(\$ 0.10 / \mathrm{W})$ reductions (in 2020 USD) in the commercial rooftop and commercial ground-mounted PV system cost benchmarks respectively. Figure 6 and Figure 7 present the U.S. national benchmarks from our commercial PV models. We model different system sizes because of the wide scope of the commercial sector, which comprises a diverse customer base occupying a variety of building and property sizes. Economies of scale - driven by hardware, labor, and related markups - are evident here. As system sizes increase, the per-watt cost to build systems decreases. As shown in Figure 6 and Figure 7, commercial rooftop applications have lower costs than commercial ground-mounted systems for several smaller system sizes. However, the difference in price decreases as system size increases, and ground-mounted systems become cost competitive at $2 \mathrm{MW}$. Compared with rooftop systems, ground-mounted applications have higher material, equipment, and labor costs that are associated with pile-driven mounting. As PV system size increases, the per-watt cost of pile-driven mounting is significantly reduced through economies of scale. Ground-mounted commercial PV systems also benefit from lower inverter costs as a result of the rapid shutdown requirements for commercial rooftop systems.

Figure 8 and Figure 9 show sensitivity analyses for the 200-kW rooftop system and 500-kW ground-mounted system, with cost categories that vary by location and hardware specification. For the rooftop system, inverter type has the largest impact on installed system cost. For the ground-mounted system, material location factor and equipment location factor have the largest impacts. 


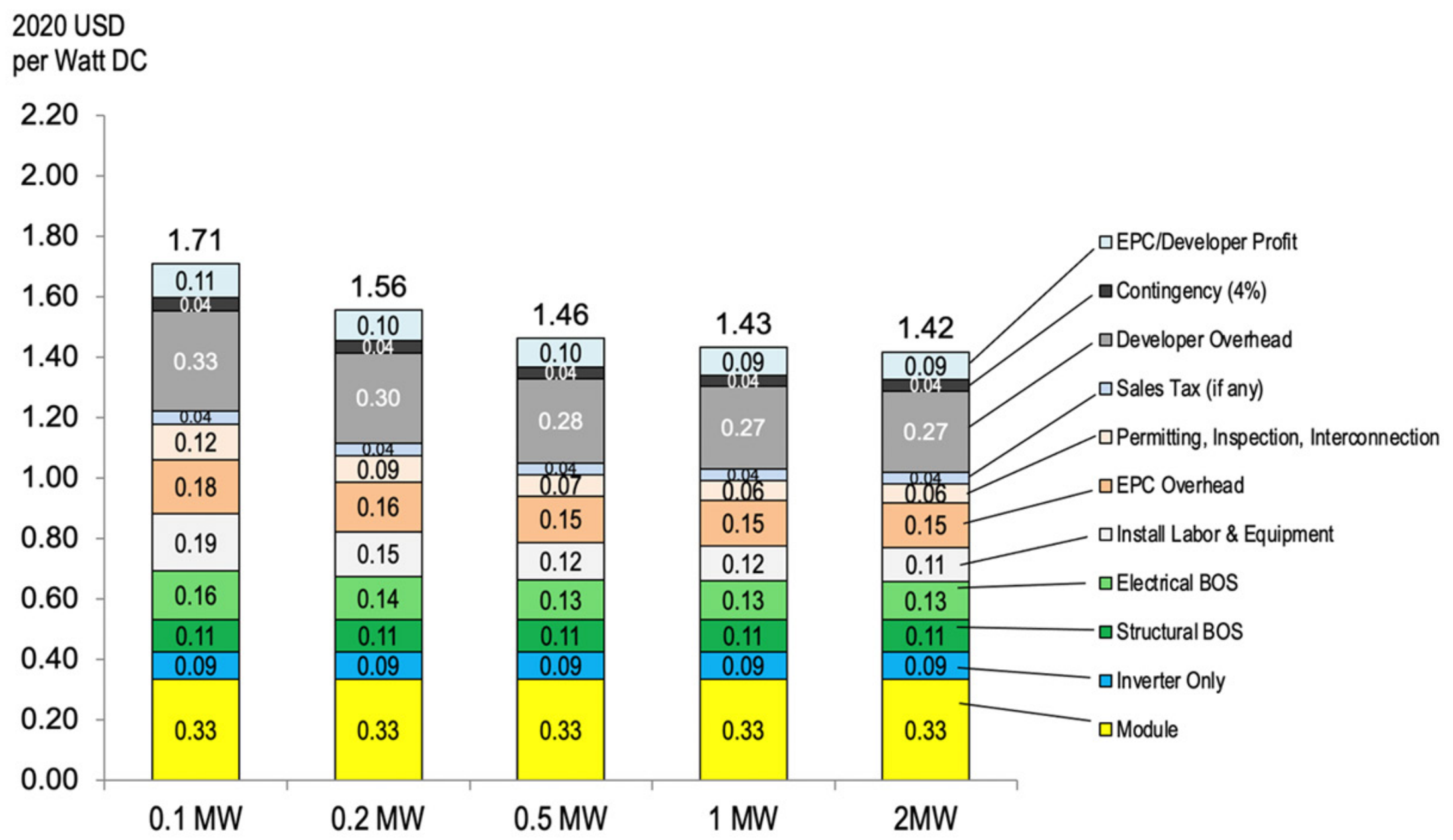

Figure 6. Q1 2021 U.S. benchmark: Commercial rooftop PV system cost (2020 USD/WDC) 
2020 USD

per Watt DC

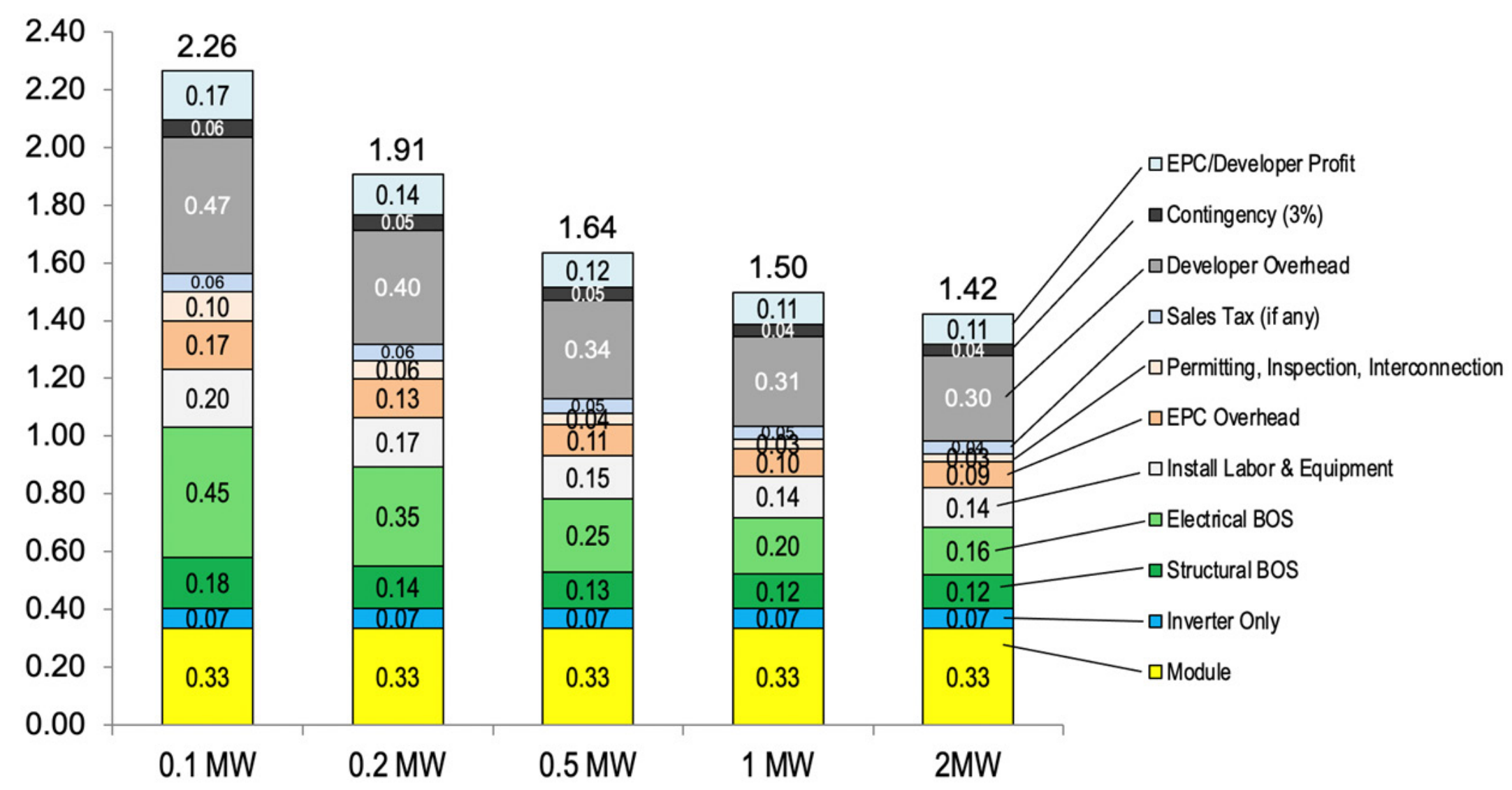

Figure 7. Q1 2021 U.S. benchmark: Commercial ground-mounted PV system cost (2020 USD/WDC) 


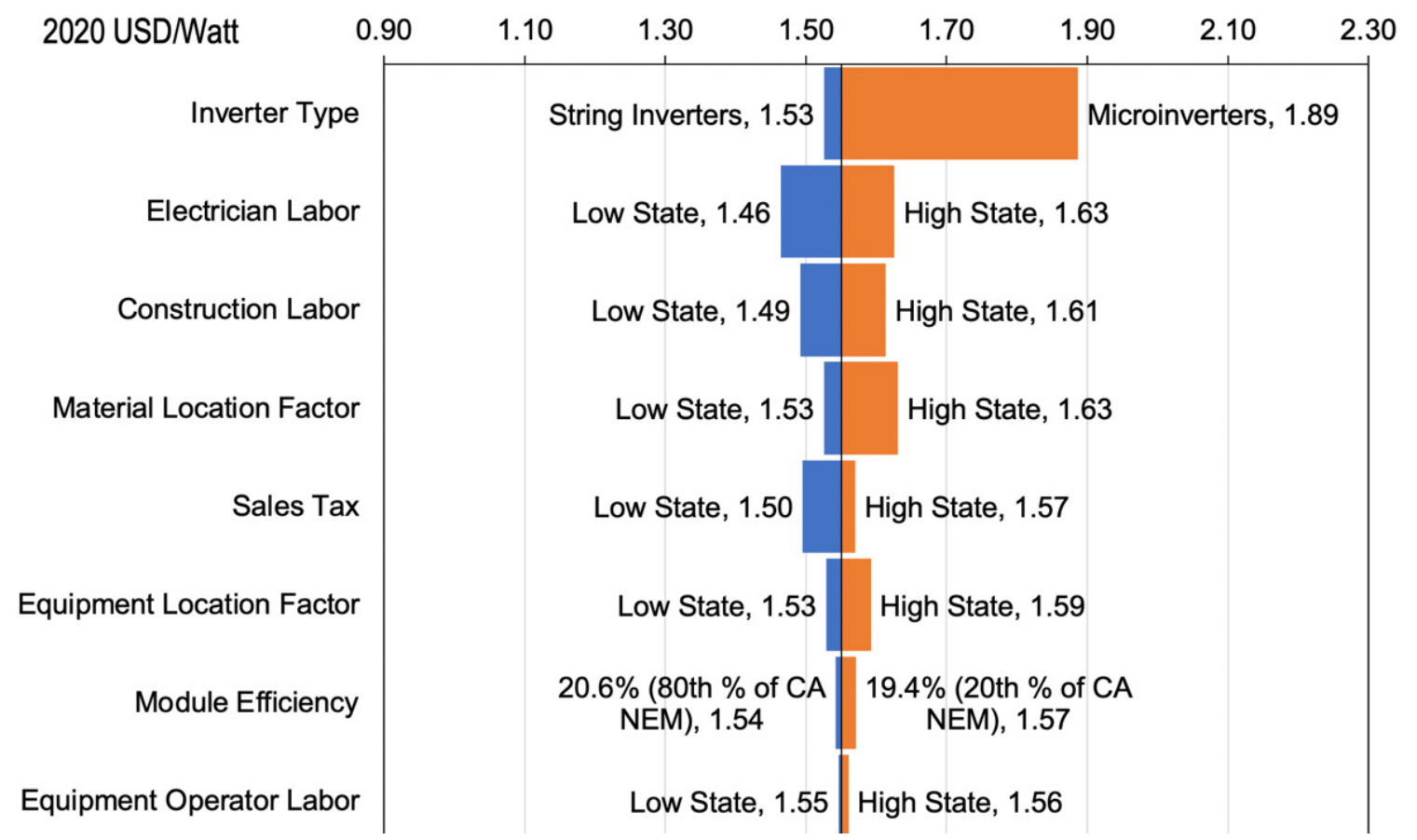

Figure 8. Sensitivity analysis for the Q1 2021 benchmark: 200-kW rooftop commercial PV system cost (2020 USD/W DC)

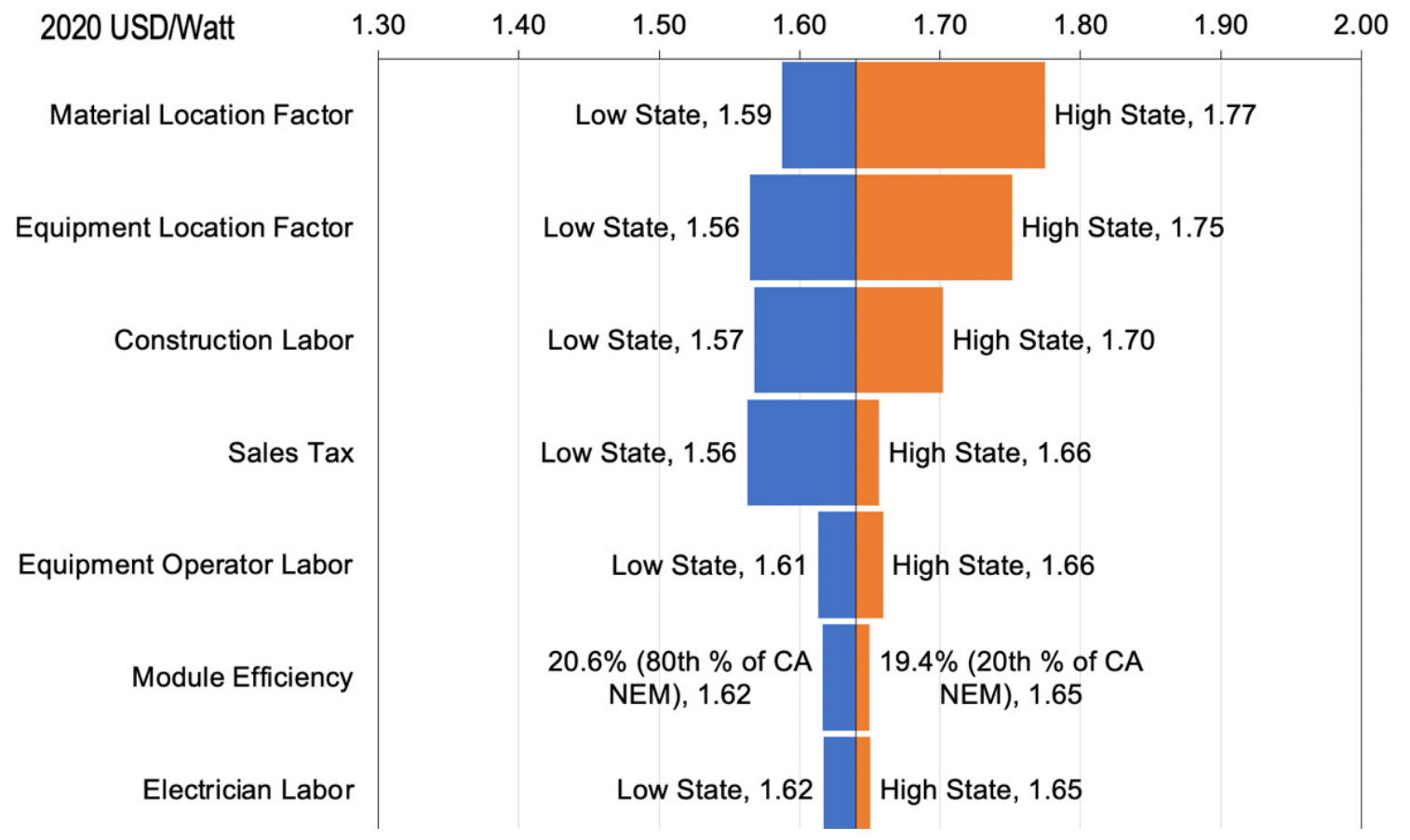

Figure 9. Sensitivity analysis for the Q1 2021 benchmark: 500-kW commercial ground-mounted PV system cost (2020 USD/W 


\section{Utility-Scale PV Model}

This section describes our utility-scale PV model's structure, inputs, and assumptions (Section 4.1) and its output (Section 4.2).

\subsection{Model Structure, Inputs, and Assumptions}

We model a baseline 100-MW $\mathrm{DC}, 1,500-\mathrm{V}_{\mathrm{DC}}$ utility-scale system using 72-cell, monocrystalline 19.9\%-efficient modules from a Tier 1 supplier and three-phase central inverters. We model both fixed-tilt and one-axis tracking on ground-mounted racking systems using driven-pile foundations. In addition, we separate our cost estimates into EPC and project-development functions. Although some firms engage in both activities in an integrated manner, we believe the distinction can help separate and highlight the specific cost trends and drivers associated with each function. We also model a range of system sizes, from $5 \mathrm{MW}_{\mathrm{DC}}$ to $100 \mathrm{MW}$ DC. Figure 10 is a schematic of our utility-scale system cost model, and Table 3 details its assumptions and inputs.

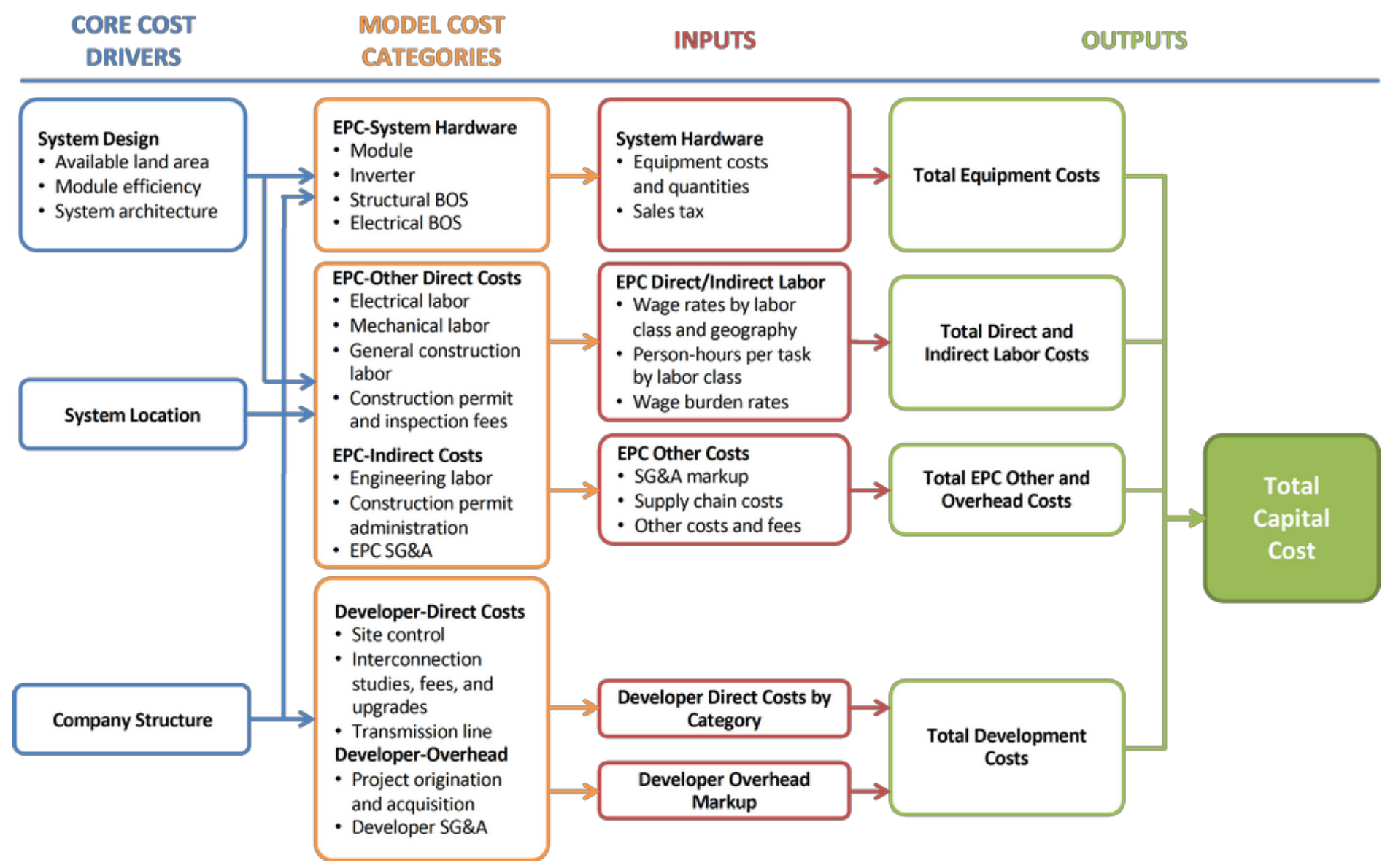

Figure 10. Utility-scale PV: Model structure 
Table 3. Utility-Scale PV: Modeling Inputs and Assumptions

\begin{tabular}{|c|c|c|c|}
\hline Category & Modeled Value & Description & Sources \\
\hline System size & $\begin{array}{l}100 \mathrm{MW} \text {; range: } \\
5 \mathrm{MW}-100 \mathrm{MW}\end{array}$ & A large utility-scale system capacity & Model assumption \\
\hline $\begin{array}{l}\text { Module } \\
\text { efficiency }\end{array}$ & $19.9 \%$ & $\begin{array}{l}\text { Average monocrystalline } \\
\text { module efficiency }\end{array}$ & CA NEM 2021 \\
\hline Module price & $\$ 0.34 / \mathrm{WDC}_{\mathrm{DC}}$ & $\begin{array}{l}\text { Ex-factory gate (first buyer) price, Tier } \\
1 \text { monocrystalline modules }\end{array}$ & $\begin{array}{l}\text { Wood Mackenzie } \\
\text { and SEIA 2021; } \\
\text { NREL } 2021\end{array}$ \\
\hline \multirow[t]{2}{*}{ Inverter price } & $\begin{array}{l}\$ 0.05 / \mathrm{W}_{\mathrm{AC}} \text { (fixed- } \\
\text { tilt) }\end{array}$ & $\begin{array}{l}\text { Ex-factory gate (first buyer) price, Tier } \\
1 \text { inverters }\end{array}$ & \multirow{2}{*}{$\begin{array}{l}\text { Wood Mackenzie and } \\
\text { SEIA 2021; Bolinger et al } \\
2020\end{array}$} \\
\hline & $\begin{array}{l}\$ 0.05 / \mathrm{W}_{\mathrm{AC}} \text { (one- } \\
\text { axis tracker) }\end{array}$ & $\begin{array}{l}\text { DC-to-AC ratio }=1.31 \text { for fixed-tilt and } \\
1.28 \text { for one-axis tracker }\end{array}$ & \\
\hline $\begin{array}{l}\text { Structural } \\
\text { components } \\
\text { (racking) }\end{array}$ & $\begin{array}{l}\$ 0.09-\$ 0.12 / W_{D C} \\
\text { for a } 100-M W \\
\text { system }\end{array}$ & $\begin{array}{l}\text { Fixed-tilt racking or one-axis tracking } \\
\text { system }\end{array}$ & $\begin{array}{l}\text { MEPS 2019; } \\
\text { model assumptions; } \\
\text { NREL } 2021\end{array}$ \\
\hline $\begin{array}{l}\text { Electrical } \\
\text { components }\end{array}$ & $\begin{array}{l}\$ 0.07-\$ 0.14 / \mathrm{W}_{\mathrm{DC}} \\
\text { Varies by system } \\
\text { size }\end{array}$ & $\begin{array}{l}\text { Model upgraded to a } 1,500-V_{D C} \\
\text { system that includes conductors, } \\
\text { conduit and fittings, transition boxes, } \\
\text { switchgear, panel boards, onsite } \\
\text { transmission, and other electrical } \\
\text { connections }\end{array}$ & $\begin{array}{l}\text { Model assumptions; } \\
\text { NREL 2021; } \\
\text { RSMeans } 2021\end{array}$ \\
\hline $\begin{array}{l}\text { EPC } \\
\text { overhead } \\
\text { (percentage } \\
\text { of equipment } \\
\text { costs) }\end{array}$ & $\begin{array}{l}8.67 \%-13 \% \text { for } \\
\text { equipment and } \\
\text { material (except } \\
\text { for transmission } \\
\text { line costs); } 23 \%- \\
69 \% \text { for labor } \\
\text { costs; varies by } \\
\text { system size and } \\
\text { labor activity }\end{array}$ & $\begin{array}{l}\text { Costs associated with EPC SG\&A, } \\
\text { warehousing, shipping, and logistics }\end{array}$ & NREL 2021 \\
\hline Sales tax & $\begin{array}{l}\text { National average: } \\
5.1 \%\end{array}$ & Sales tax on equipment costs & RSMeans 2021 \\
\hline \multirow{2}{*}{$\begin{array}{l}\text { Direct } \\
\text { installation } \\
\text { labor }\end{array}$} & $\begin{array}{l}\text { Electrician: } \\
\$ 27.36 / \text { hour }\end{array}$ & \multirow[t]{2}{*}{$\begin{array}{l}\text { Modeled labor rate assumes national } \\
\text { average nonunionized labor }\end{array}$} & \multirow[t]{2}{*}{ BLS 2020; NREL 2021} \\
\hline & $\begin{array}{l}\text { Laborer: } \\
\$ 18.22 / \text { hour }\end{array}$ & & \\
\hline $\begin{array}{l}\text { Burden rates } \\
\text { (percentage } \\
\text { of direct } \\
\text { labor) }\end{array}$ & $\begin{array}{l}\text { Total nationwide } \\
\text { average: } 31.7 \%\end{array}$ & $\begin{array}{l}\text { Workers' compensation, federal and } \\
\text { state unemployment insurance, } \\
\text { Federal Insurance Contributions Act, } \\
\text { builders' risk, public liability }\end{array}$ & RSMeans 2021 \\
\hline \multirow[t]{2}{*}{ PII } & $\$ 0.02-\$ 0.06 / \mathrm{W}_{\mathrm{DC}}$ & \multirow{2}{*}{$\begin{array}{l}\text { For construction permits fee, } \\
\text { interconnection, testing, and } \\
\text { commissioning }\end{array}$} & \multirow[t]{2}{*}{ NREL 2021} \\
\hline & $\begin{array}{l}\text { Varies by system } \\
\text { size }\end{array}$ & & \\
\hline
\end{tabular}




\begin{tabular}{|c|c|c|c|}
\hline Category & Modeled Value & Description & Sources \\
\hline \multirow{4}{*}{$\begin{array}{l}\text { Transmission } \\
\text { line (gen-tie } \\
\text { line) }\end{array}$} & \multirow{4}{*}{$\begin{array}{l}\$ 0.00-\$ 0.01 / \mathrm{W}_{\mathrm{DC}} \\
\text { Varies by system } \\
\text { size }\end{array}$} & System size $<10 \mathrm{MW}$ uses 0 miles & \multirow{4}{*}{$\begin{array}{l}\text { Model assumptions; } \\
\text { NREL } 2021\end{array}$} \\
\hline & & $\begin{array}{l}\text { for gen-tie line, thus no transmission } \\
\text { cost }\end{array}$ & \\
\hline & & $\begin{array}{l}\text { System size }>200 \mathrm{MW} \text { uses five } \\
\text { miles for gen-tie line }\end{array}$ & \\
\hline & & $\begin{array}{l}\text { System size }=10-200 \mathrm{MW} \text { uses } \\
\text { linear interpolation }\end{array}$ & \\
\hline \multirow{2}{*}{$\begin{array}{l}\text { Developer } \\
\text { overhead }\end{array}$} & $2 \%-12 \%$ & \multirow{2}{*}{$\begin{array}{l}\text { Includes overhead expenses such as } \\
\text { payroll, facilities, travel, legal fees, } \\
\text { administrative, business } \\
\text { development, finance, and other } \\
\text { corporate functions }\end{array}$} & \multirow{2}{*}{$\begin{array}{l}\text { Model assumptions; } \\
\text { NREL } 2021\end{array}$} \\
\hline & $\begin{array}{l}\text { Varies by system } \\
\text { size }(100 \mathrm{MW} \\
\text { uses } 2 \% ; 5 \mathrm{MW} \\
\text { uses } 12 \%)\end{array}$ & & \\
\hline Contingency & $3 \%$ & Estimated as markup on EPC cost & NREL 2021 \\
\hline \multirow[t]{2}{*}{ Profit } & $5 \%-8 \%$ & \multirow{2}{*}{$\begin{array}{l}\text { Applies a percentage margin to all } \\
\text { costs including hardware, installation } \\
\text { labor, EPC overhead, and developer } \\
\text { overhead }\end{array}$} & \multirow[t]{2}{*}{ NREL 2021} \\
\hline & $\begin{array}{l}\text { Varies by system } \\
\text { size (100 MW } \\
\text { uses } 5 \% ; 5 \mathrm{MW} \\
\text { uses } 8 \%)\end{array}$ & & \\
\hline
\end{tabular}

\subsection{Model Output}

Figure 11 (page 19) shows the U.S. national benchmark (EPC + developer) for fixed-tilt and oneaxis tracker systems, using nonunionized labor. Figure 12 shows a sensitivity analysis for the one-axis system benchmark, with cost categories that vary by location and hardware specification. Equipment location factor has the largest impact on installed system cost. 


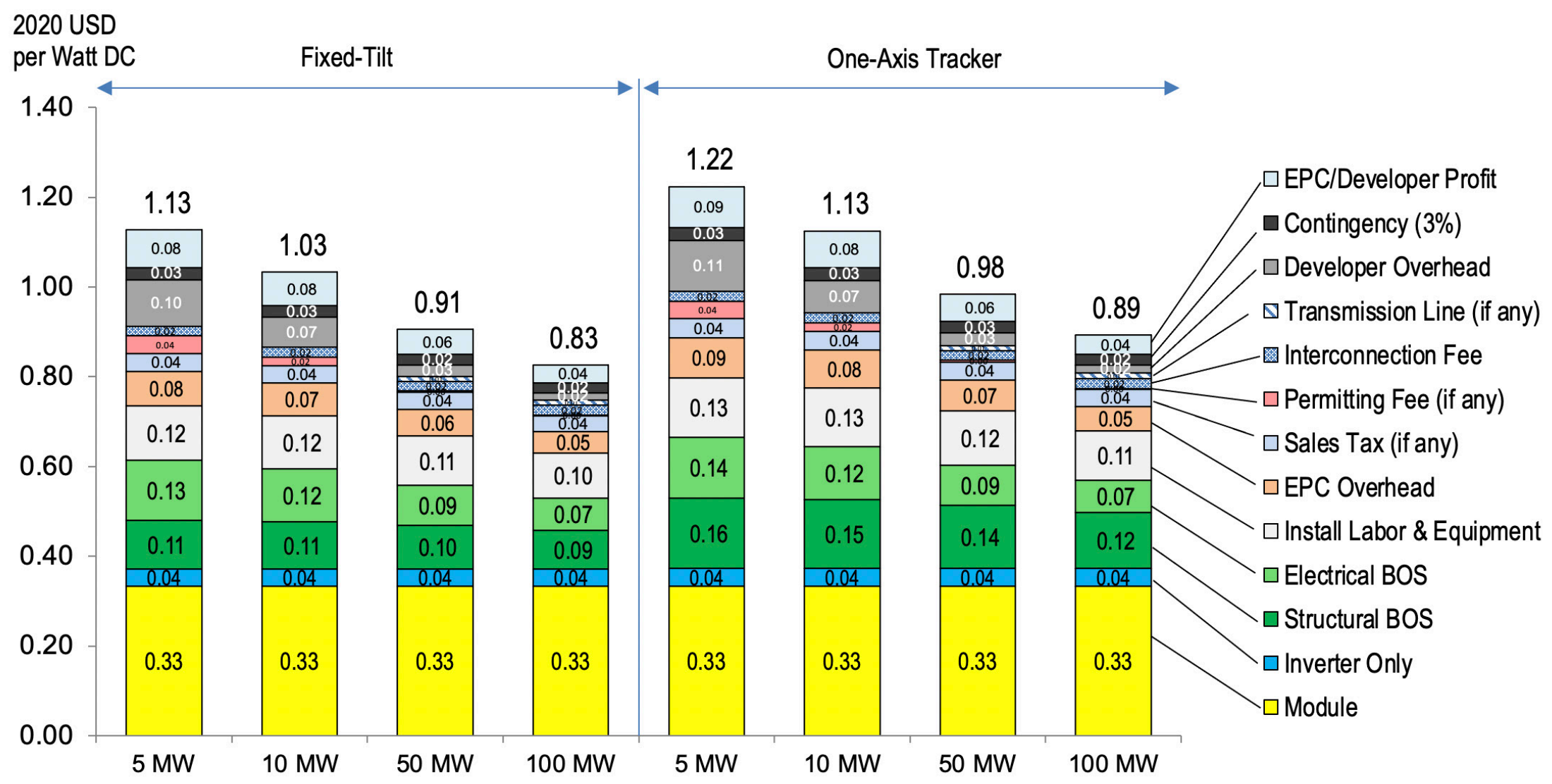

Figure 11. Q1 2021 U.S. benchmark: Utility-scale PV total cost (EPC + developer), 2020 USD/WDC 


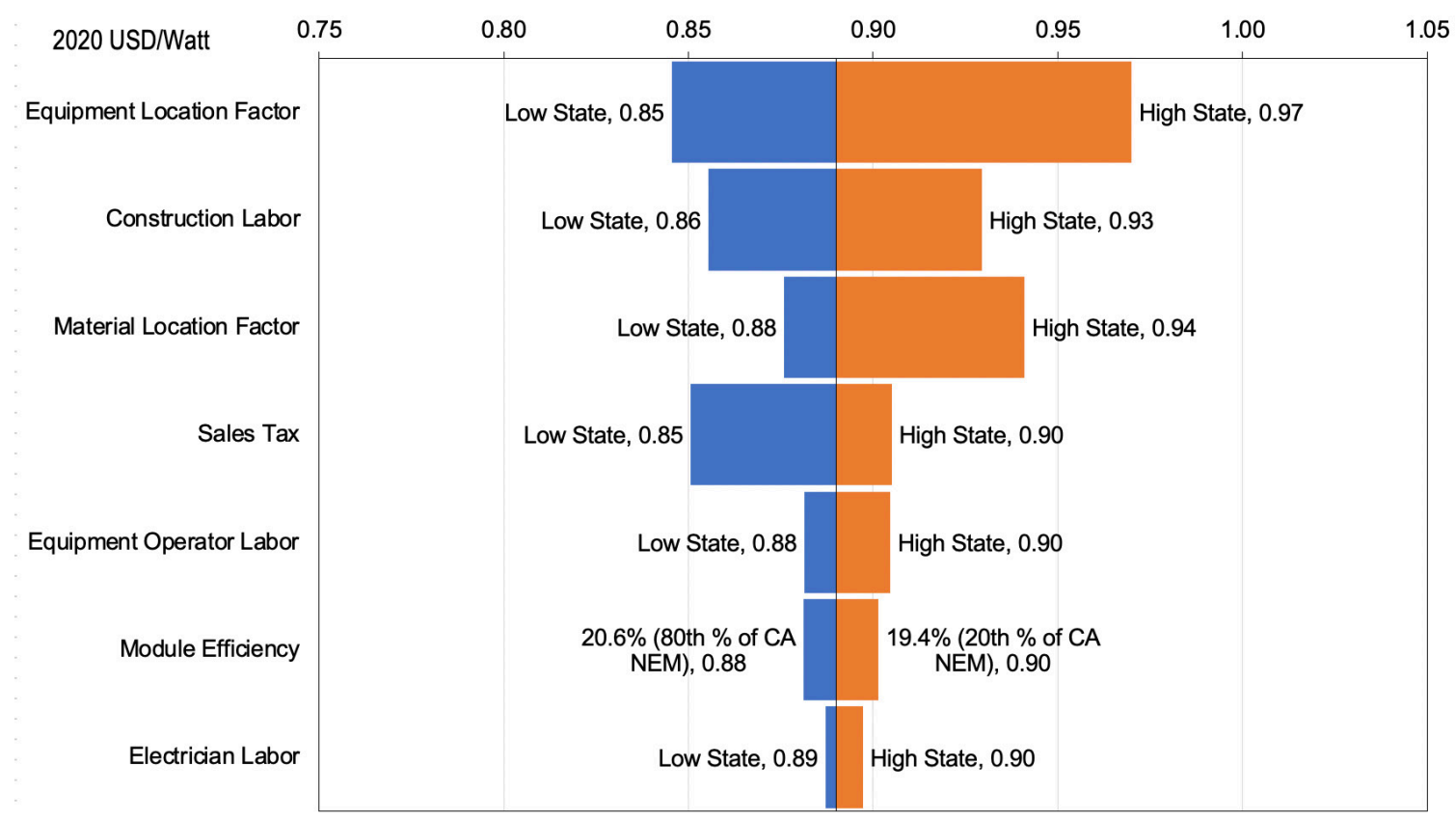

Figure 12. Sensitivity analysis for the Q1 2021 benchmark: 100-MW one-axis utility-scale PV system cost (2020 USD/W 


\section{Residential Storage and PV-Plus-Storage Model}

To analyze component costs and system prices for PV-plus-storage installed in Q1 2021, we adapt NREL's component- and system-level modeling approach for stand-alone PV. For this report, system configuration refers to four characteristics that determine a PV-plus-storage system's functionality:

- PV system capacity $(\mathrm{kW})$

- Battery energy capacity $(\mathrm{kWh})$

- Battery power capacity $(\mathrm{kW})$

- Whether the battery is DC- or AC-coupled. ${ }^{9}$

Customer preference for specific characteristics is based on several factors, including cost, load profile, and planned use of the system for load shifting (storing energy in one period for use in a later period). In general, customers who have loads with high peaks of short duration may desire a high-power (high-kW) battery capable of meeting the high peak. Customers who have flatter loads with lower peaks of longer duration may prefer a high-energy (high-kWh) battery capable of longer-duration energy discharge. Because of the historic levels of residential PV-plus-storage installations, we now have significantly more system characteristic data on which to base our benchmark (unlike previous benchmarking reports in which we used optimization calculations). We benchmark a $5-\mathrm{kW}(12.5-\mathrm{kWh})$ residential battery system, based on data reported by Barbose, Elmallah, and Gorman (2021).

A PV array, a battery, and a battery-based inverter are the fundamental components of every PVplus-storage system. Additional component requirements are determined by whether the system is DC- or AC-coupled ${ }^{10}$ : a DC-coupled system often requires a charge controller to step down the PV output voltage to a level that is safe for the battery, whereas an AC-coupled system requires a grid-tied inverter to feed PV output directly to the customer's load or the grid. ${ }^{11}$ For a detailed discussion of the differences and considerations related to DC-versus AC-coupled system configurations, see Ardani et al. (2017).

Sections 5.1 and 5.2 present the residential storage and PV-plus-storage cost models, and Section 5.3 shows the model outputs.

\subsection{Li-lon Stand-Alone Storage System Cost Model}

The residential storage market is predominantly composed of fully integrated storage kits, which include Li-ion battery packs, inverters, field wiring, disconnect, and casing. Although this equipment is sold as one product, we model these components separately to compare costs across

\footnotetext{
${ }^{9}$ NREL's modeled DC-coupled system includes a single dual-function inverter that is tied to both the PV array and the battery. In our AC-coupled system, to charge a battery, PV power is first converted (DC to AC) through a gridtied inverter and then converted (AC to DC) through a battery-based inverter.

${ }^{10}$ Our discussion is simplified to explain the basic technical differences between AC- and DC-coupled systems. The decision to use AC- or DC-coupling might also be driven by nontechnical factors such as policy, contractual obligations, and economics.

${ }^{11}$ Some Li-ion battery packs have built-in safety controls, such as those integrated in a battery management system, but some do not. For consistency, our model assumes there is a dedicated charge controller.
} 
storage kit sizes and configurations. Table 4 presents the detailed modeling inputs and assumptions for the residential stand-alone storage costs.

Table 4. Residential Storage-Only Modeling Inputs and Assumptions

\begin{tabular}{|c|c|c|}
\hline Category & Modeled Value & Description \\
\hline System size & $5 \mathrm{~kW} / 12.5 \mathrm{kWh}$ storage & Typical U.S. residential battery system \\
\hline Battery pack cost & $\$ 221 / \mathrm{kWh}$ nameplate & Battery pack only \\
\hline $\begin{array}{l}\text { Battery-based } \\
\text { inverter cost }\end{array}$ & $\$ 167 / \mathrm{kWh}$ nameplate & $\begin{array}{l}\text { 8-kW, } 48-\mathrm{V} \text { bidirectional inverter } \\
\text { (more resilient) }\end{array}$ \\
\hline $\begin{array}{l}\text { Electrical } \\
\text { BOS cost }\end{array}$ & $\begin{array}{l}\text { - } \$ 1,578 \text { (DC-coupled) } \\
\text { - } \$ 1,335 \text { (AC-coupled) } \\
\text { Assumes higher electrical BOS costs } \\
\text { for DC-coupled systems because of the } \\
\text { need for a charge controller }\end{array}$ & $\begin{array}{l}\text { Revenue-grade meter, communications } \\
\text { device, AC main panel, DC disconnect, } \\
\text { maximum power point tracking, charge } \\
\text { controller, subpanel (breaker box) for } \\
\text { critical load, conduit, wiring, DC cable }\end{array}$ \\
\hline $\begin{array}{l}\text { Supply-chain } \\
\text { costs }\end{array}$ & $5 \%$ of cost of equipment & $\begin{array}{l}\text { Includes costs of inventory, shipping, and } \\
\text { handling of equipment }\end{array}$ \\
\hline Sales tax & $5.1 \%$ (national average) & Sales tax on the equipment \\
\hline $\begin{array}{l}\text { Installation labor } \\
\text { cost }\end{array}$ & $\begin{array}{l}\text { Electrician: } \$ 27.36 / \text { hour } \\
\text { Laborer: } \$ 18.22 / \text { hour } \\
\text { For AC systems, we assume extra } \\
\text { labor hours of work due to an additional } \\
\text { inverter and extra wiring. }\end{array}$ & Assumes national average pricing \\
\hline Engineering fee & $\$ 98$ & $\begin{array}{l}\text { Engineering design and professional } \\
\text { engineer-stamped calculations and } \\
\text { drawings }\end{array}$ \\
\hline PII & $\begin{array}{l}\$ 295 \text { permit fee } \\
\$ 1,133-\$ 1639 \text { in labor }\end{array}$ & $\begin{array}{l}20-32 \text { hours (DC-coupled/AC-coupled) of } \\
\text { commissioning and interconnection labor, } \\
\text { and permit fee }\end{array}$ \\
\hline $\begin{array}{l}\text { Sales and } \\
\text { marketing } \\
\text { (customer } \\
\text { acquisition) }\end{array}$ & $\$ 0.54 / \mathrm{WDC}_{\mathrm{D}}$ & $\begin{array}{l}20 \text { hours more time for DC system, and } \\
32 \text { hours more for AC system, per closed } \\
\text { sale, associated with selling a storage } \\
\text { system versus selling a PV system }\end{array}$ \\
\hline $\begin{array}{l}\text { Overhead } \\
\text { (general and } \\
\text { administrative) }\end{array}$ & $\$ 0.25 / W_{D C}$ & $\begin{array}{l}\text { Rent, building, equipment, staff expenses } \\
\text { not directly tied to PII, customer } \\
\text { acquisition, or direct installation labor }\end{array}$ \\
\hline Profit (\%) & $17 \%$ & $\begin{array}{l}\text { Fixed percentage margin applied to all } \\
\text { direct costs, including hardware, } \\
\text { installation labor, direct sales and } \\
\text { marketing, design, installation, and } \\
\text { permitting fees }\end{array}$ \\
\hline
\end{tabular}


As demonstrated in Figure 13, the kit for a $5-\mathrm{kW} / 12.5-\mathrm{kWh}$ storage system costs approximately $\$ 6,406-\$ 6,662$ with a total installed cost of $\$ 15,852$ (DC-coupled) to $\$ 16,715$ (AC-coupled). ${ }^{12}$ Also, Figure 14 (page 24) shows the cost of residential storage systems for different system capacities.

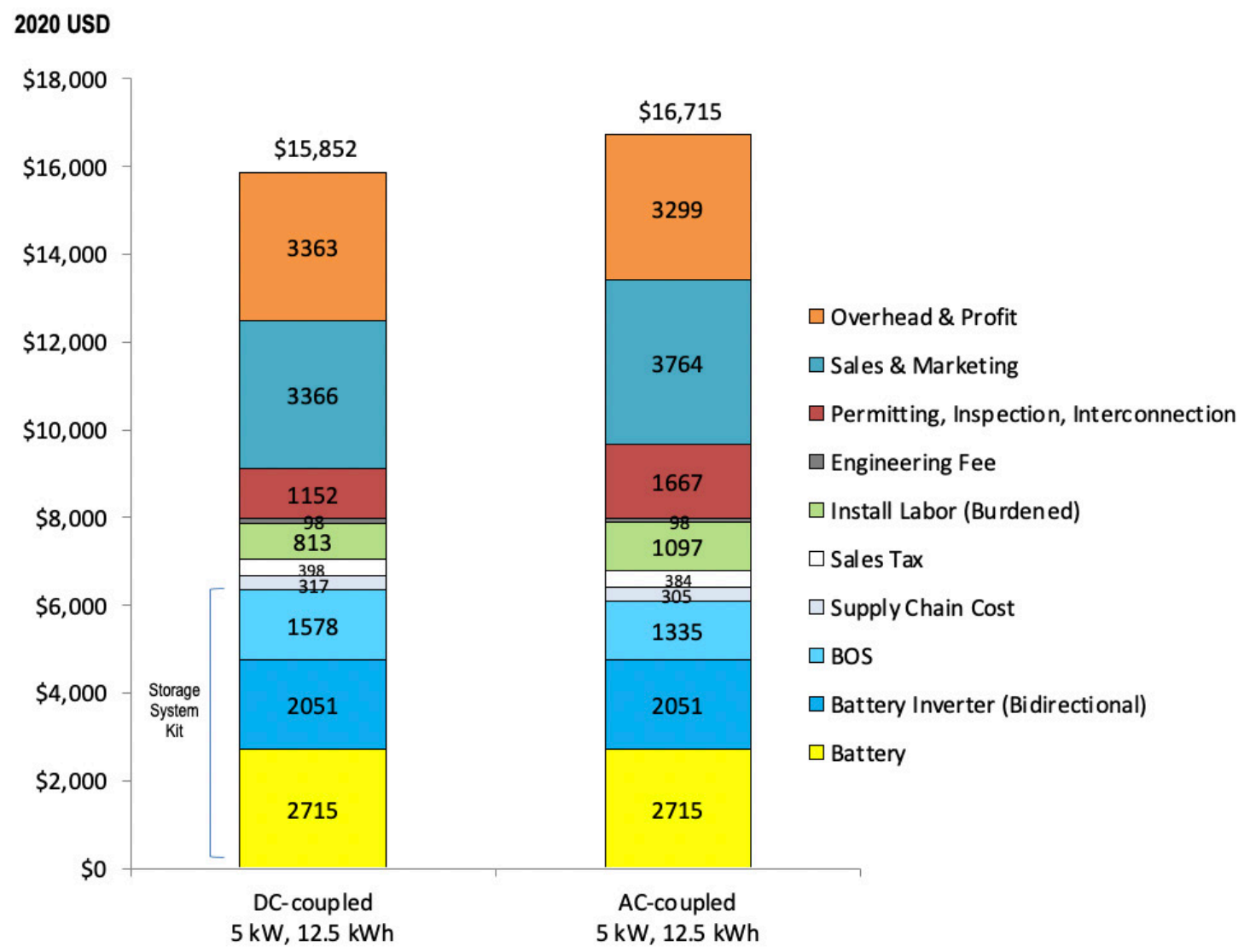

Figure 13. Installed cost of typical residential storage system only

Figure 14 shows the range in cost of typical stand-alone storage system sizes currently in the marketplace. Though we assume no economies of scale in our residential storage cost model, as demonstrated in the figure, certain costs are fixed regardless of the system size, reducing the cost per unit of capacity as the system size increases.

\footnotetext{
${ }^{12} \mathrm{We}$ assume all batteries are installed inside the home. Installation of batteries outside would require additional BOS hardware, such as a concrete pad and associated container. Such additional BOS hardware would add to the benchmarked price of our modeled systems.
} 


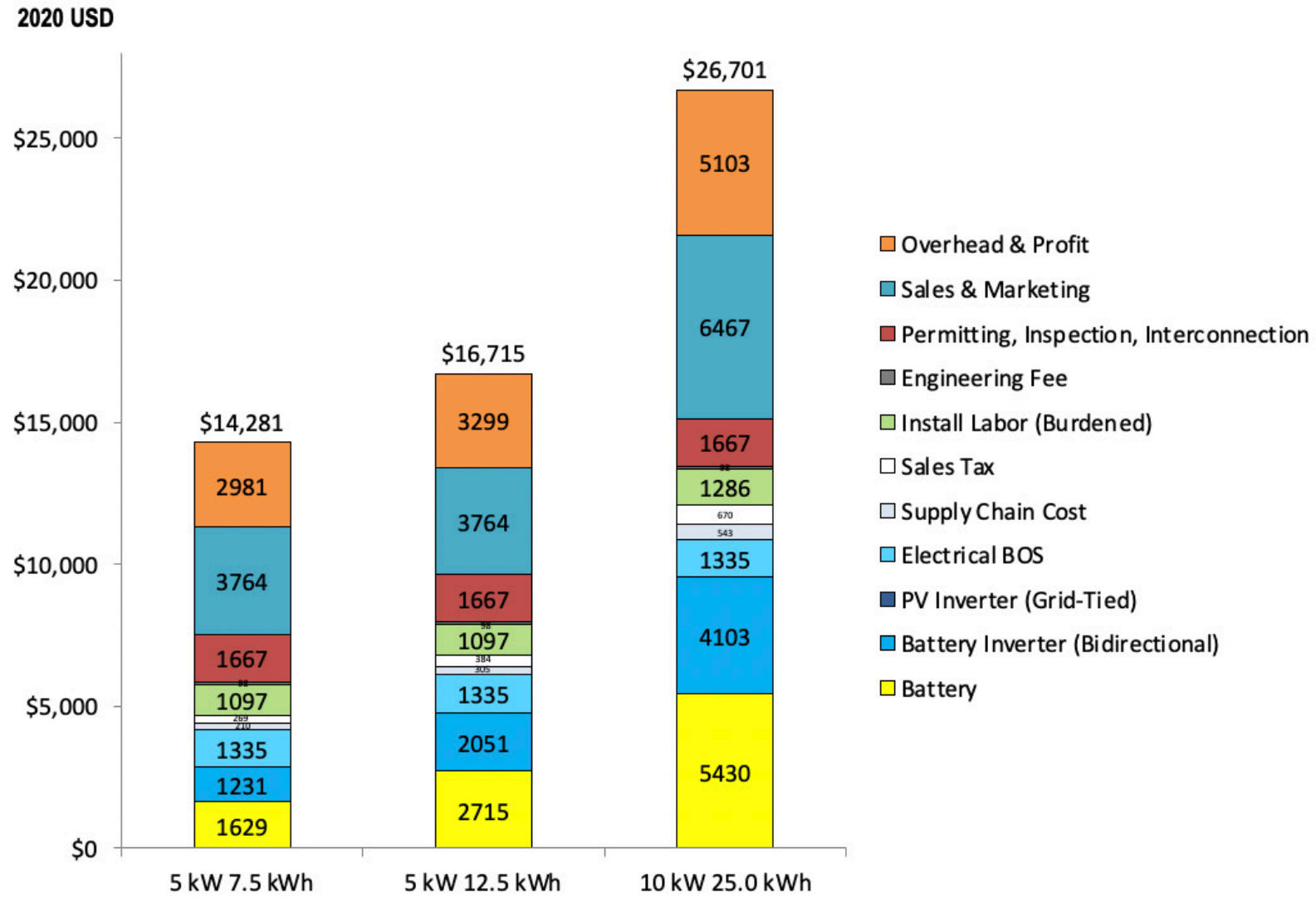

Figure 14. Installed cost of stand-alone residential storage system by size

BESS is battery energy storage system

\subsection{PV-Plus-Storage System Cost Model}

We model a 7-kW PV system coupled with a 5-kW/12.5-kWh storage system using the same PV assumptions we use with our stand-alone PV system. Figure 15 is a schematic of typical DC- and AC-coupled PV systems with battery back-up. Table 5 presents model changes to residential PV and storage system cost model when PV and storage are combined. 


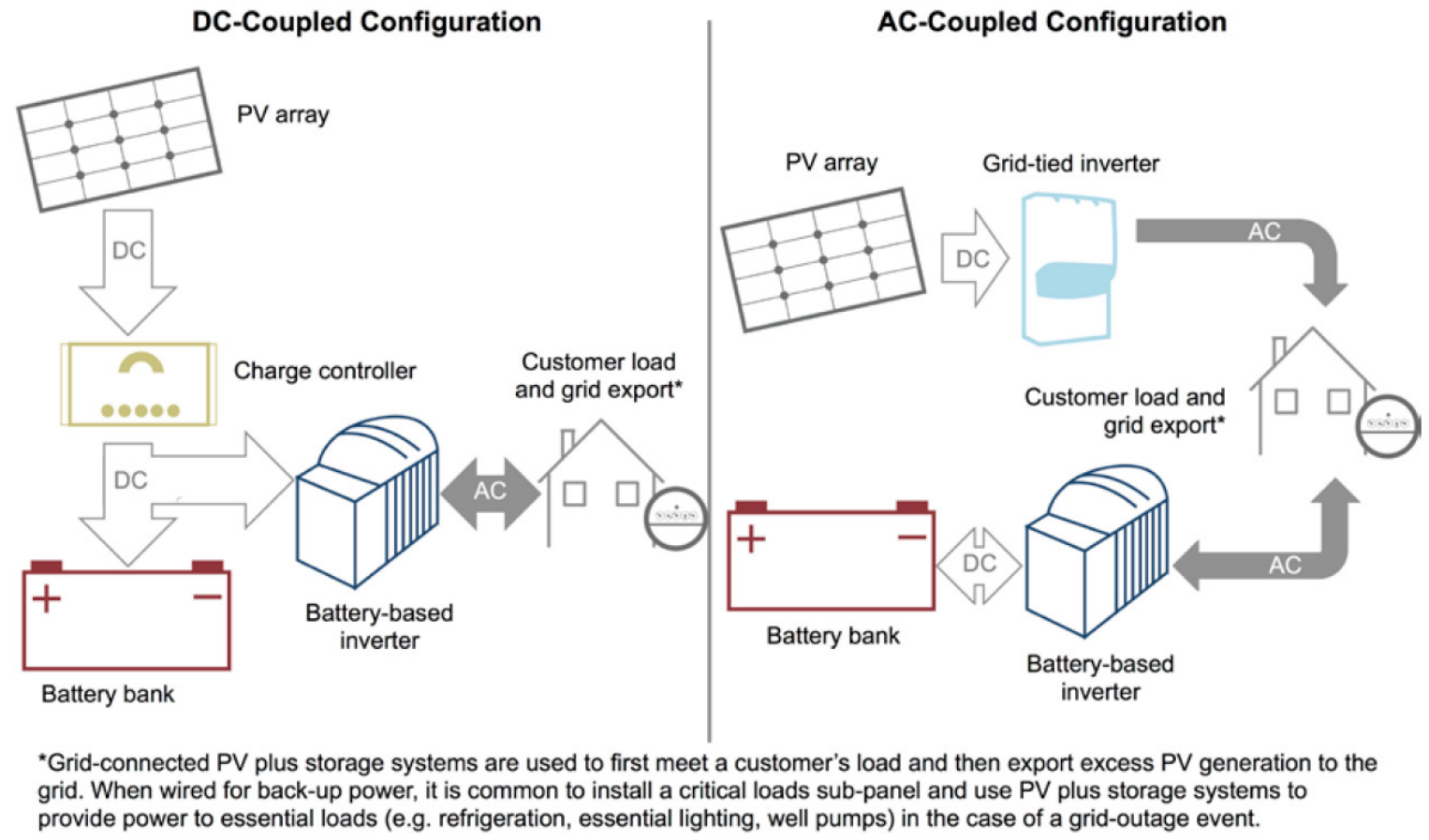

Figure 15. Modeled DC- and AC-coupled system configurations

Figure is simplified for illustrative purposes.

Source: Feldman et al. 2021

Table 5. Changes to Residential PV and Storage Models When PV and Storage Are Combined

\begin{tabular}{|c|c|c|}
\hline Category & Modeled Value & Description \\
\hline Electrical BOS & $\begin{array}{l}90 \% \text { of the combined BOS costs for PV } \\
\text { and battery stand-alone systems }\end{array}$ & Duplicative parts are removed. \\
\hline $\begin{array}{l}\text { Installation } \\
\text { labor }\end{array}$ & $\begin{array}{l}90 \% \text { of the combined BOS costs for PV } \\
\text { and battery stand-alone systems }\end{array}$ & Duplicative work is removed. \\
\hline $\begin{array}{l}\text { Sales and } \\
\text { marketing }\end{array}$ & $\begin{array}{l}20 \text { hours more time for DC system, and } \\
32 \text { hours more for AC system, per } \\
\text { closed sale, associated with selling a PV } \\
\text { system with storage }\end{array}$ & $\begin{array}{l}\text { Additional explanation, calculations, and a } \\
\text { lower close rate, and the AC system } \\
\text { requires more customer site assessment. }\end{array}$ \\
\hline
\end{tabular}

\subsection{Model Output}

Figure 16 compares cost and price components for a stand-alone PV system as well as PV-plusstorage systems with stand-alone storage systems. With AC-coupling, the price of the system is $\$ 33,756$, which is $\$ 3,306(10.9 \%)$ more than the price of the DC-coupled system $(\$ 30,450)$. 
2020 USD

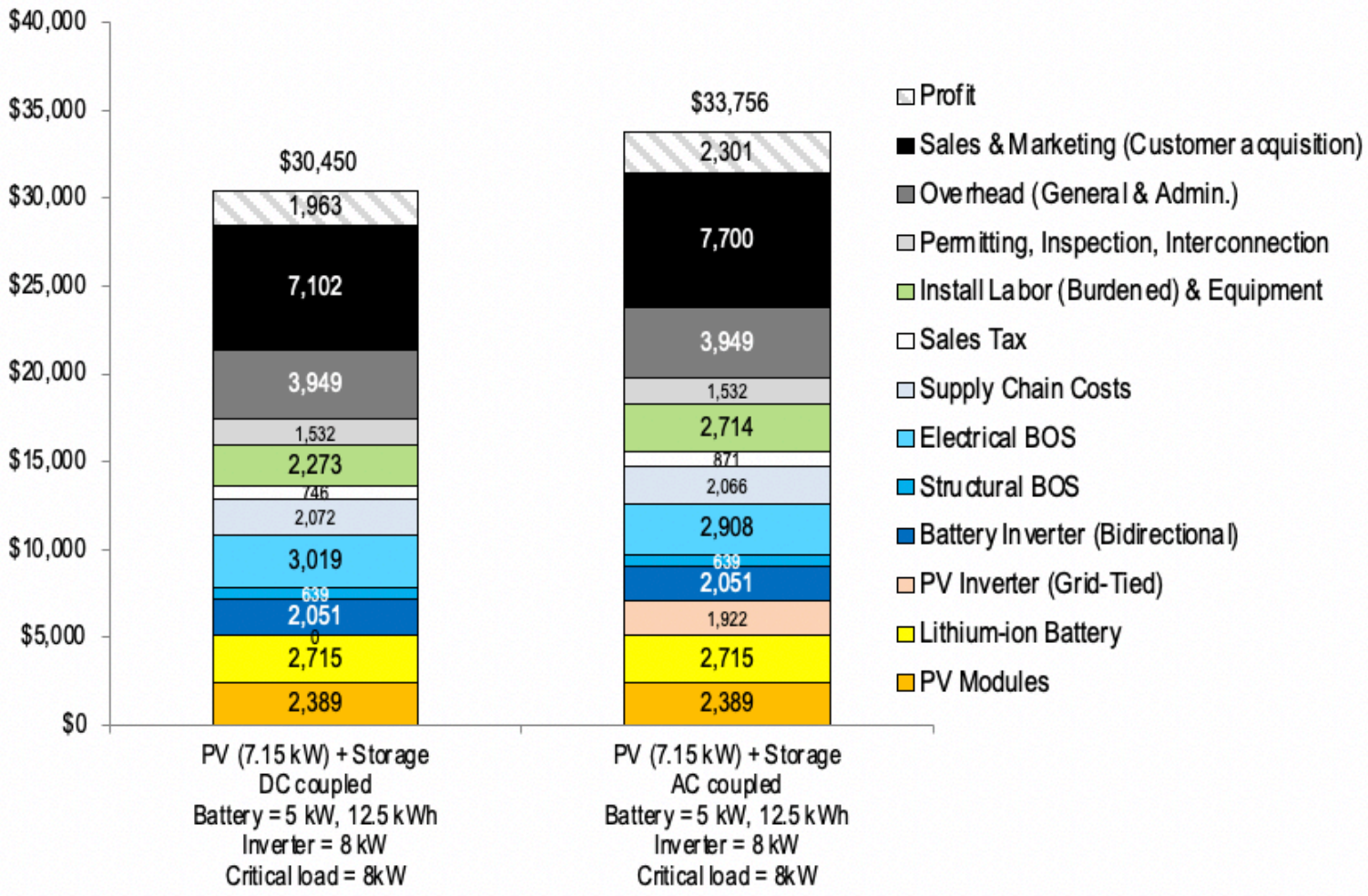

Figure 16. Modeled total installed cost and price components for residential PV-plus-storage systems, DC-coupled versus AC-coupled case (2020 USD) 


\section{Commercial Storage and PV-Plus-Storage Model}

To analyze component costs and system prices for commercial PV-plus-storage installed in Q1 2021, we adapt NREL's component- and system-level modeling approach for stand-alone PV in a similar manner as we did for the residential PV-plus-storage system. Customer preference for specific characteristics is based on several factors, including cost, load profile, and planned use of the system for load shifting (storing energy in one period for use in a later period). In general, customers who have loads with high peaks of short duration may desire a high-power (high-kW) battery capable of meeting the high peak. Customers who have flatter loads with lower peaks of longer duration may prefer a high-energy (high-kWh) battery capable of longer-duration energy discharge.

Sections 6.1 and 6.2 present the commercial storage and PV-plus-storage cost models, and Section 6.3 shows the model outputs.

\subsection{Li-Ion Stand-Alone Storage System Cost Model}

To reduce installation costs, some battery manufacturers may combine Li-ion battery cells, a battery management system, and the battery inverter in one compact unit (Sonnen Batterie 2018) as an AC battery. However, in this report, we focus on traditional DC batteries typically configured with the components shown in Figure 17 and Figure 18.

\begin{tabular}{l}
$\begin{array}{l}\text { Battery cells } \rightarrow \text { modules } \rightarrow \text { packs } \rightarrow \text { racking } \\
\text { system (DC) }\end{array}$ \\
$\begin{array}{l}\text { Storage container } \\
\text { (HVAC system, thermal management, } \\
\text { monitors and controls, fire suppression, } \\
\text { switchgear, and energy management system) }\end{array}$ \\
\hline $\begin{array}{l}\text { Power conversion system } \\
\text { (bidirectional inverter to convert AC to DC for } \\
\text { battery charging and DC to AC for discharging) }\end{array}$ \\
\hline $\begin{array}{l}\text { Transformer (to step up 480-V inverter output } \\
\text { to } 12-66 \mathrm{kV} \text { ) }\end{array}$ \\
\hline
\end{tabular}

Figure 17. Traditional commercial and utility-scale Li-ion battery energy storage components HVAC = heating, ventilating, and air conditioning 


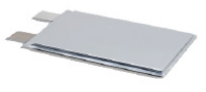

Battery Cell

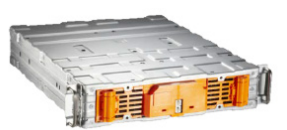

Battery

Module

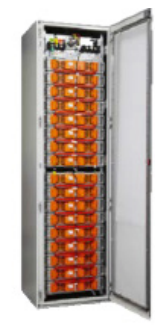

Battery Racks

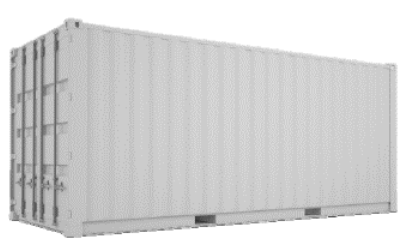

Battery Container

Figure 18. Battery system components

Source: 2018 North American Generator Forum/Energy Systems Integration Group Workshop

Table 6 lists our model inputs and assumptions for a commercial energy storage system. We determine the battery size $\left.(600 \mathrm{~kW})_{\mathrm{DC}}\right)^{13}$ using an inverter loading ratio of 1.3 and an inverter/storage size ratio of 1.67, based on Denholm, Eichman, and Margolis (2017).

Table 6. Commercial Li-ion Energy Storage System: Model Inputs and Assumptions

\begin{tabular}{|c|c|c|c|}
\hline $\begin{array}{l}\text { Model } \\
\text { Component }\end{array}$ & Modeled Value & Description & Sources \\
\hline $\begin{array}{l}\text { Battery total } \\
\text { size }\end{array}$ & $\begin{array}{l}600 \mathrm{~kW} \mathrm{DC} \\
2.40 \mathrm{MWh} \text { usable } \\
3.12 \mathrm{MWh} \text { nameplate }\end{array}$ & $\begin{array}{l}\text { Baseline case to match a 1-MW } \\
\text { PV system }\end{array}$ & NREL 2021 \\
\hline $\begin{array}{l}\text { Battery size } \\
\text { per container }\end{array}$ & $\begin{array}{l}5 \mathrm{MWh} \text { per } 40-\mathrm{ft} \\
\text { container }\end{array}$ & 1 container & NREL 2021 \\
\hline $\begin{array}{l}\text { Li-ion battery } \\
\text { price }(\$ / \mathrm{kWh} \\
\text { usable) }\end{array}$ & $\begin{array}{l}0.5 \text { hours: } \$ 229 / \mathrm{kWh} \text { usable } \\
1 \text { hour: } \$ 211 / \mathrm{kWh} \text { usable } \\
2 \text { hours: } \$ 168 / \mathrm{kWh} \text { usable } \\
4 \text { hours: } \$ 165 / \mathrm{kWh} \text { usable }\end{array}$ & Ex-factory gate (first buyer) prices & BNEF 2020 \\
\hline Duration & $0.5-4.0$ hours & Duration determines energy (MWh). & NREL 2021 \\
\hline RTE & $90 \%$ & Round trip efficiency & NREL 2021 \\
\hline $\begin{array}{l}\text { Min. state of } \\
\text { charge (SOC) } \\
\text { and max. SOC }\end{array}$ & $10 \%$ and $90 \%$ & Minimum and maximum state of charge & NREL 2021 \\
\hline $\begin{array}{l}\text { Battery central } \\
\text { inverter price }\end{array}$ & $\$ 0.06 / \mathrm{W}$ & Ex-factory gate (first buyer) prices & $\begin{array}{l}\text { Wood Mackenzie } \\
2019\end{array}$ \\
\hline
\end{tabular}

\footnotetext{
${ }^{13}$ For a 1-MW PV system with an inverter loading ratio of 1.3 and inverter/storage size ratio of 1.67, maximum deliverable power at point of interconnection is $1.37 \mathrm{MW}_{\mathrm{AC}}(1-\mathrm{MW} / 1.3+1 \mathrm{MW} / 1.67)$ for AC-coupled systems and $770 \mathrm{~kW}_{\mathrm{AC}}(1 \mathrm{MW} / 1.3)$ for DC-coupled systems.
} 


\begin{tabular}{|c|c|c|c|}
\hline $\begin{array}{l}\text { Model } \\
\text { Component }\end{array}$ & Modeled Value & Description & Sources \\
\hline Battery cabinet & $\$ 0.21-\$ 0.90$ & $\begin{array}{l}\text { Includes battery packs, containers, } \\
\text { thermal management system and fire } \\
\text { suppression system }\end{array}$ & NREL 2021 \\
\hline Electrical BOS & $\$ 0.18 / \mathrm{W}$ & $\begin{array}{l}\text { Includes conduit, wiring, DC cable, } \\
\text { energy management system, } \\
\text { switchgear, transformer, and monitor } \\
\text { and controls for each container; costs } \\
\text { impacted by number of containers, } \\
\text { number of transformers, and row } \\
\text { spacing }\end{array}$ & NREL 2021 \\
\hline Structural BOS & $\$ 0.04 / \mathrm{W}$ & $\begin{array}{l}\text { Includes foundation and inverter house; } \\
\text { costs impacted by numbers of inverters } \\
\text { and transformers }\end{array}$ & NREL 2021 \\
\hline $\begin{array}{l}\text { Installation } \\
\text { labor }\end{array}$ & $\begin{array}{l}\text { Electrician: } \$ 27.36 / \text { hour } \\
\text { Laborer: } \$ 18.22 / \text { hour }\end{array}$ & $\begin{array}{l}\text { National average modeled labor rate } \\
\text { assumes nonunionized labor. }\end{array}$ & BLS 2020 \\
\hline Sales tax & $5.1 \%$ (national average) & Sales tax on the equipment & RSMeans 2021 \\
\hline $\begin{array}{l}\text { EPC overhead } \\
\text { and profit }\end{array}$ & $\begin{array}{l}8.67 \% \text { for equipment and } \\
\text { material; } 23 \%-69 \% \text { for } \\
\text { labor costs; varies by } \\
\text { system size, labor } \\
\text { activity, and location }\end{array}$ & $\begin{array}{l}\text { Costs associated with EPC SG\&A, } \\
\text { warehousing, shipping, and logistics }\end{array}$ & NREL 2021 \\
\hline $\begin{array}{l}\text { Developer } \\
\text { cost: } \\
\text { developer } \\
\text { overhead }\end{array}$ & $\begin{array}{l}6 \% \text { of total installation } \\
\text { cost }\end{array}$ & $\begin{array}{l}\text { Includes overhead expenses such as } \\
\text { payroll, facilities, travel, legal fees, } \\
\text { administrative, business development, } \\
\text { finance, and other corporate functions }\end{array}$ & NREL 2021 \\
\hline $\begin{array}{l}\text { Developer } \\
\text { cost: Pll }\end{array}$ & $\$ 0.03 / \mathrm{W}$ & $\begin{array}{l}\text { Construction permits fee, } \\
\text { interconnection study, interconnection } \\
\text { inspection, and interconnection fee }\end{array}$ & NREL 2021 \\
\hline $\begin{array}{l}\text { Developer } \\
\text { cost: } \\
\text { contingency }\end{array}$ & $4 \%$ & $\begin{array}{l}\text { Estimated as markup on the total } \\
\text { EPC cost }\end{array}$ & NREL 2021 \\
\hline $\begin{array}{l}\text { Developer } \\
\text { cost: } \\
\text { EPC/developer } \\
\text { net profit }\end{array}$ & $5 \%$ & $\begin{array}{l}\text { Applies a percentage margin to all } \\
\text { costs including hardware, installation } \\
\text { labor, EPC overhead, and developer } \\
\text { overhead }\end{array}$ & NREL 2021 \\
\hline
\end{tabular}

\footnotetext{
a In previous benchmarking reports, we reported cost only in terms of nameplate capacity. This year, based on the feedback from our commercial and industrial partners, we report commercial- and utility-scale stand-alone storage system costs in terms of both usable and nameplate capacity, where usable capacity is the total capacity deliverable at the point of interconnection after round-trip efficiency (RTE) loss and SOC limitations. This is only applicable for commercial- and utility-scale systems, as the upfront capacity overbuild cost is significantly higher than that of smaller residential stand-alone storage systems.
} 
We use these inputs to calculate energy storage cost via the following equation ${ }^{14}$ :

$$
\begin{gathered}
\text { Energy storage installation cost }\left(\frac{\$}{k W h}\right)= \\
\text { Battery cost }\left(\frac{\$}{k W h}\right)+\frac{\text { Other cost components }(\$) \text { such as battery inverter and labor }}{\text { Storage system size }(k W) \times \text { Duration }(\text { hours })}
\end{gathered}
$$

Figure 19 shows the resulting costs in nameplate and usable capacity $(\$ / \mathrm{kWh})$ for $600-\mathrm{kW} \mathrm{Li-}$ ion energy storage systems, which vary from $\$ 481 / \mathrm{kWh}$-usable (4-hour duration) to $\$ 2,154 / \mathrm{kWh}$-usable (0.5-hour duration). The battery cabinet cost accounts for $47 \%$ of total system cost in the 4-hour system but only $19 \%$ in the 0.5 -hour system. At the same time, nonbattery cost categories account for an increasing proportion of the system cost as duration declines.

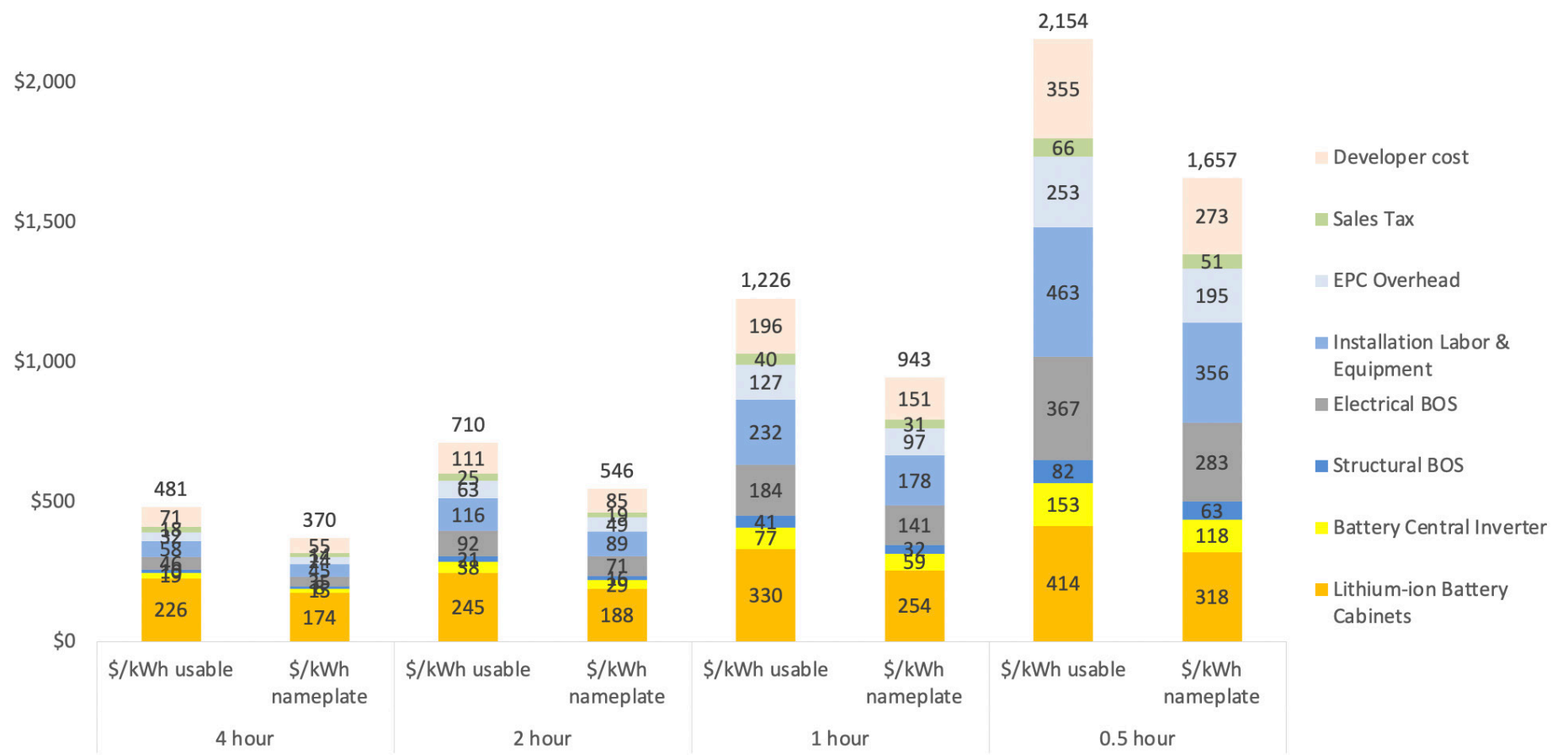

Figure 19. U.S. Commercial Li-Ion Battery Stand-Alone Storage Costs for Durations of 0.5-4.0 Hours (600 kW DC), Q1 2021

\footnotetext{
${ }^{14}$ This equation is only for the energy storage installation cost calculation; for levelized cost of storage (LCOS), the equation would be different. LCOS is not covered in this report.
} 


\subsection{PV-Plus-Storage System Cost Model}

We model a 1-MW DC commercial fixed-tilt ground-mounted PV plus 600-kWstorage system, with 0.5 hours $(300 \mathrm{kWh}$ Usable $), 1$ hour $\left(600 \mathrm{kWh}_{\text {Usable }}\right), 2$ hours $\left(1.2 \mathrm{MWh}_{\text {Usable }}\right)$, and 4 hours $(2.4$ $\mathrm{MWh}_{\text {Usable }}$ ) of storage, using the same PV assumptions we use with our stand-alone PV system. Figure 15 (page 25) is a schematic of typical DC- and AC-coupled PV systems with battery back-up.

Table 7 represents model changes to commercial PV and storage system cost model when PV and storage are combined.

Table 7. Changes to Commercial PV and Storage Models When PV and Storage Are Combined

\begin{tabular}{lll}
\hline Category & Modeled Value & Description \\
\hline Electrical BOS & $\begin{array}{l}90 \% \text { of the combined BOS costs for PV } \\
\text { and battery stand-alone systems }\end{array}$ & Duplicative parts are removed \\
\hline $\begin{array}{l}\text { Installation } \\
\text { labor }\end{array}$ & $\begin{array}{l}90 \% \text { of the combined BOS costs for PV } \\
\text { and battery stand-alone systems }\end{array}$ & Duplicative work is removed \\
\hline $\begin{array}{l}\text { Sales and } \\
\text { marketing }\end{array}$ & $\begin{array}{l}\text { 20 hours more time for DC system, and } \\
\text { 32 hours more for AC system, per } \\
\text { closed sale, associated with selling a PV } \\
\text { system with storage }\end{array}$ & $\begin{array}{l}\text { Additional explanation, calculations, and a } \\
\text { lower close rate; also, the AC system } \\
\text { requires more customer site assessment }\end{array}$ \\
\hline
\end{tabular}

\subsection{Model Output}

Figure 20 summarizes our model results for several system types and configurations:

- Stand-alone 1-MW $W_{D C}$ commercial fixed-tilt ground-mounted PV system (\$1.50 million)

- Stand-alone 600-kW/2.4-MWhUsable, 4-hour-duration energy storage system ( $\$ 1.15$ million ${ }^{15}$ )

- DC-coupled PV (1-MW) plus storage (600 kW/2.4 MWh $\mathrm{Msable}_{\text {, }}$ 4-hour duration) system (\$2.05 million)

- AC-coupled PV (1-MW) plus storage (600 kW/2.4 MWhUsable, 4-hour duration) system (\$1.97 million)

- PV (1-MW) plus storage (600 kW/2.4 MWh $\mathrm{Msable}_{\text {, }}$ 4-hour duration) system with PV and storage components sited in different locations ( $\$ 2.62$ million).

Colocating the PV and storage subsystems produces cost savings by reducing costs related to site preparation; permitting and interconnection; installation labor; hardware (via sharing of hardware such as switchgears, transformers, and controls); overhead; and profit. The cost of the hybrid AC-coupled system is $25 \%$ lower than the cost of the system with PV and storage sited separately.

\footnotetext{
15 The total cost of a stand-alone commercial energy storage system with a power rating of $\mathrm{P}(\mathrm{kW})$ and storage duration $\mathrm{H}(\mathrm{hrs})$ can also be represented using the following linear equation:
}

Total System Cost $=\$ 965.83 * \mathrm{P}+\$ 237.64 * \mathrm{P} * \mathrm{H}$ with an $\mathrm{R}$ squared value of 99.7 
Using DC-coupling rather than AC-coupling results in a 4.5\% higher total cost, which is the net result of cost differences between $\mathrm{DC}$-coupling and $\mathrm{AC}$-coupling in the categories of solar inverter, DC-DC converter, and related structural and electrical balance of system costs.

However, for an actual project, cost savings may not be the only factor in choosing DC- or ACcoupling; additional factors - such as retrofit considerations, system performance (including energy loss that is due to clipping), design flexibility, and O\&M-should be considered.

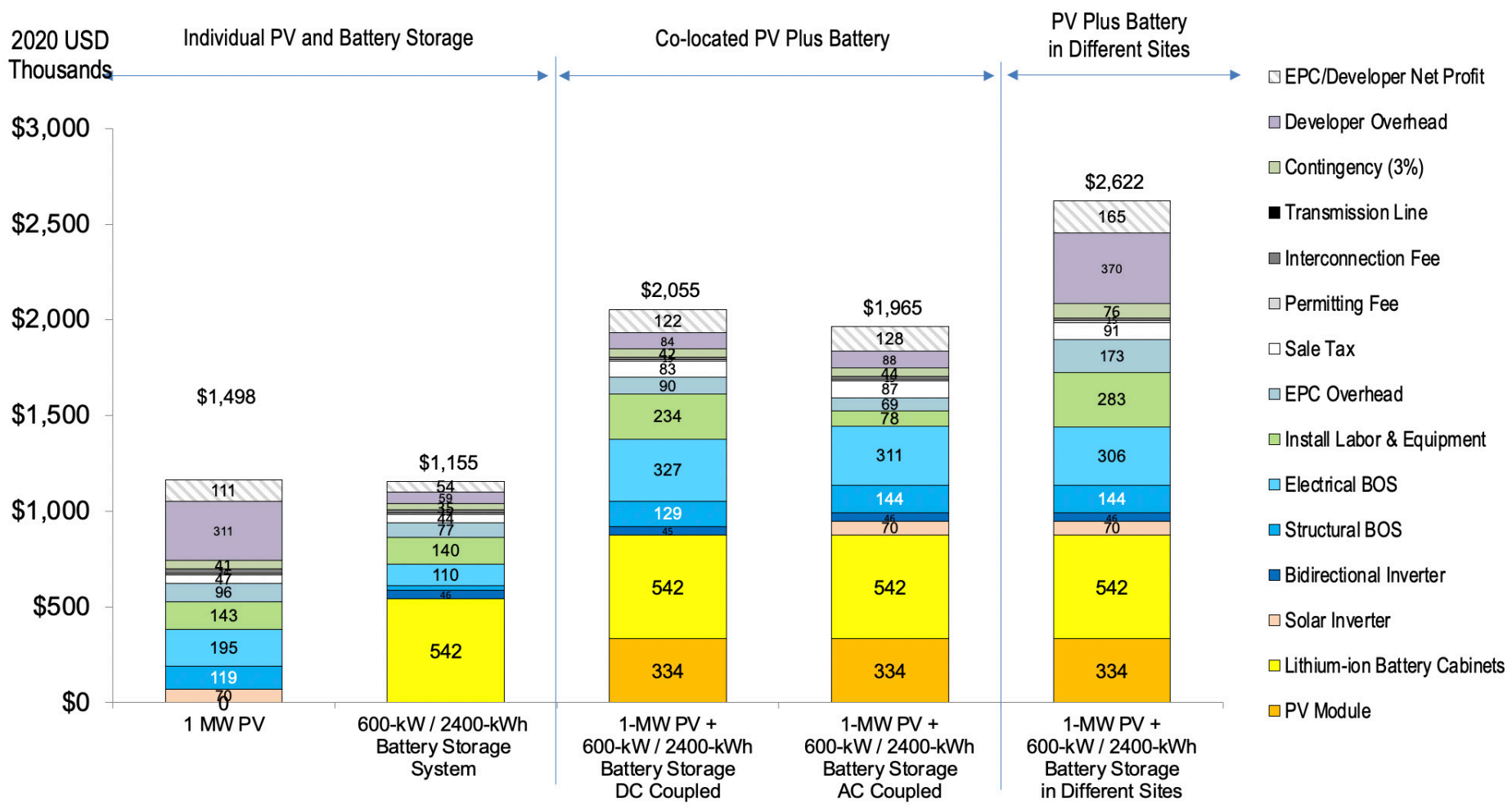

Figure 20. Cost benchmark for Commercial PV-plus-storage systems (4-hour duration) in different sites and the same site (DC-coupled and AC-coupled cases), Q1 2021 


\section{Utility-Scale Storage and PV-Plus-Storage Model}

Figure 21 details the bottom-up cost structure of our stand-alone utility-scale storage model, which uses a structure similar to our previously developed PV cost model (Fu et al. 2015, 2016, 2017; Fu, Feldman, and Margolis 2018b; Fu, Remo, and Margolis 2018; Feldman et al. 2021). Total system upfront capital costs are broken into EPC costs and developer costs. EPC nonhardware, or "soft," costs are driven by labor rates and labor productivities. We adapt engineering-design and cost-estimating models from RSMeans (2021) to determine the EPC hardware costs (including module/battery racking, mounting, wiring, containerization, and foundation) and related EPC soft costs (including related labor and equipment hours required in any given U.S. location).

Sections 7.1 and 7.2 present the utility-scale storage and PV-plus-storage cost models, and Section 7.3.3 shows the model outputs.

CORE COST DRIVERS
MODEL COST CATEGORIES
INPUTS

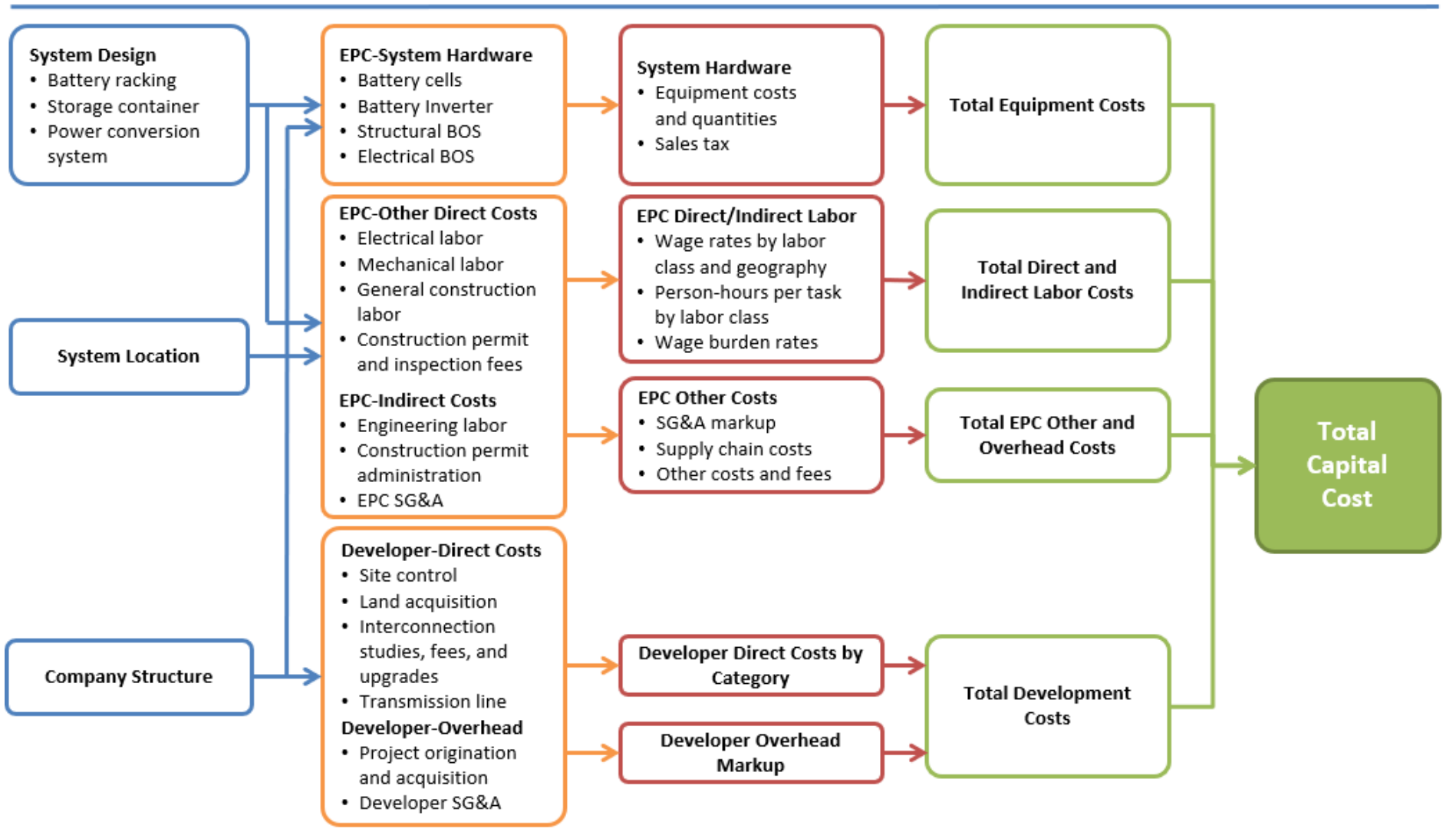

Figure 21. Structure of the bottom-up cost model for utility-scale stand-alone storage systems 


\subsection{Li-Ion Stand-Alone Storage System Cost Model}

The major storage components we model for utility-scale stand-alone storage systems are the same as those summarized in Figure 17 (page 27) and Figure 18 (page 28) for the commercial stand-alone storage model. Table 8 lists our model inputs and assumptions for such a utility-scale energy storage system. We determine the battery size $\left(60 \mathrm{MW}_{\mathrm{DC}}\right)^{16}$ using an inverter loading ratio of 1.3 and an inverter/storage size ratio of 1.67, based on Denholm, Eichman, and Margolis (2017). We use PV system capacity and its characteristics to determine the optimal stand-alone storage capacity.

Table 8. Utility-Scale Li-ion Energy Storage System: Model Inputs and Assumptions

\begin{tabular}{|c|c|c|c|}
\hline $\begin{array}{l}\text { Model } \\
\text { Component }\end{array}$ & Modeled Value & Description & Source \\
\hline $\begin{array}{l}\text { Battery total } \\
\text { size }\end{array}$ & $\begin{array}{l}60 \mathrm{MW} D \\
240 \mathrm{MWh} \text { usable } \\
312 \mathrm{MWh} \text { nameplate }\end{array}$ & $\begin{array}{l}\text { Baseline case to match a } 100-\mathrm{MW} \\
\text { PV system }\end{array}$ & NREL 2021 \\
\hline $\begin{array}{l}\text { Battery size per } \\
\text { container }\end{array}$ & $5 \mathrm{MWh}$ per 40-ft container & $\begin{array}{l}\text { Assumption to compute the number } \\
\text { of containers }\end{array}$ & NREL 2021 \\
\hline $\begin{array}{l}\text { Li-ion battery } \\
\text { price }(\$ / \mathrm{kWh} \\
\text { usable) }\end{array}$ & $\begin{array}{l}0.5 \text { hours: } \$ 229 / \mathrm{kWh} \text { usable } \\
1 \text { hour: } \$ 211 / \mathrm{kWh} \text { usable } \\
2 \text { hours: } \$ 168 / \mathrm{kWh} \text { usable } \\
4 \text { hours: } \$ 165 / \mathrm{kWh} \text { usable }\end{array}$ & Ex-factory gate (first buyer) prices & BNEF 2020 \\
\hline Duration & $0.5-4.0$ hours & Duration determines energy (MWh) & NREL 2021 \\
\hline RTE & $90 \%$ & Round-trip efficiency & \\
\hline $\begin{array}{l}\text { Min. SOC and } \\
\text { max. SOC }\end{array}$ & $10 \%$ and $90 \%$ & Minimum and maximum state of charge & \\
\hline $\begin{array}{l}\text { Battery central } \\
\text { inverter price }\end{array}$ & $\$ 0.06 / \mathrm{W}_{\mathrm{AC}}$ & Ex-factory gate (first buyer) prices & $\begin{array}{l}\text { Wood Mackenzie } \\
2019\end{array}$ \\
\hline Battery cabinet & $\$ 0.15-\$ 0.89 / \mathrm{W}$ & $\begin{array}{l}\text { Includes battery packs, containers, } \\
\text { thermal management system and fire } \\
\text { suppression system. }\end{array}$ & NREL 2021 \\
\hline Inverter size & $\begin{array}{l}2.5 \mathrm{MW} \text { per inverter } \\
\text { ( } 24 \text { inverters) }\end{array}$ & $\begin{array}{l}\text { Used to determine the number of } \\
\text { battery inverters }\end{array}$ & NREL 2021 \\
\hline Electrical BOS & $\$ 0.06-\$ 0.15 / \mathrm{W}$ & $\begin{array}{l}\text { Includes conduit, wiring, DC cable, } \\
\text { energy management system, } \\
\text { switchgear, transformer, and monitor }\end{array}$ & NREL 2021 \\
\hline
\end{tabular}

\footnotetext{
${ }^{16}$ For a 100-MW PV system with an inverter loading ratio of 1.3 and an inverter/storage size ratio of 1.67 , and assuming battery inverter capacity is equal to battery DC capacity maximum deliverable power at point of interconnection is $137 \mathrm{MW}_{\mathrm{AC}}(100 \mathrm{MW} / 1.3+100 \mathrm{MW} / 1.67)$ for AC-coupled systems and $77 \mathrm{MW}_{\mathrm{AC}}(100 \mathrm{MW} / 1.3)$ for DC-coupled systems.
} 


\begin{tabular}{|c|c|c|c|}
\hline $\begin{array}{l}\text { Model } \\
\text { Component }\end{array}$ & Modeled Value & Description & Source \\
\hline & & $\begin{array}{l}\text { and controls for each container; } \\
\text { determined by number of containers, } \\
\text { number of transformers, and row } \\
\text { spacing }\end{array}$ & \\
\hline Structural BOS & $\$ 0.01 / \mathrm{W}$ & $\begin{array}{l}\text { Includes foundation and inverter house; } \\
\text { costs impacted by number of inverters, } \\
\text { number of transformers, and the } \\
\text { spacing between containers. }\end{array}$ & NREL 2021 \\
\hline $\begin{array}{l}\text { Installation } \\
\text { labor }\end{array}$ & $\begin{array}{l}\text { Electrician: } \$ 27.36 / \text { hour } \\
\text { Laborer: } \$ 18.22 / \text { hour }\end{array}$ & $\begin{array}{l}\text { National average modeled labor rate } \\
\text { assumes nonunionized labor }\end{array}$ & BLS 2020 \\
\hline Sales tax & $5.1 \%$ (national average) & Sales tax on the equipment & RSMeans 2021 \\
\hline $\begin{array}{l}\text { EPC overhead } \\
\text { and profit }\end{array}$ & $\begin{array}{l}8.67 \% \text { for equipment and } \\
\text { material; } 23 \%-69 \% \text { for } \\
\text { labor costs; varies by } \\
\text { system size, and labor } \\
\text { activity }\end{array}$ & $\begin{array}{l}\text { Costs associated with EPC SG\&A, } \\
\text { warehousing, shipping, and logistics }\end{array}$ & NREL 2021 \\
\hline $\begin{array}{l}\text { Developer cost: } \\
\text { developer } \\
\text { overhead }\end{array}$ & $\begin{array}{l}3 \% \text { of total installation } \\
\text { cost }\end{array}$ & $\begin{array}{l}\text { Includes overhead expenses such as } \\
\text { payroll, facilities, travel, legal fees, } \\
\text { administrative, business development, } \\
\text { finance, and other corporate functions }\end{array}$ & NREL 2021 \\
\hline $\begin{array}{l}\text { Developer cost: } \\
\text { PII }\end{array}$ & $\$ 0.02 / \mathrm{W}$ & $\begin{array}{l}\text { Construction permits fee, } \\
\text { interconnection study, interconnection } \\
\text { inspection, and interconnection fee }\end{array}$ & NREL 2021 \\
\hline $\begin{array}{l}\text { Developer cost: } \\
\text { contingency }\end{array}$ & $3 \%$ & $\begin{array}{l}\text { Estimated as markup on the total } \\
\text { EPC cost }\end{array}$ & NREL 2021 \\
\hline $\begin{array}{l}\text { Developer cost: } \\
\text { EPC/developer } \\
\text { net profit }\end{array}$ & $5 \%$ & $\begin{array}{l}\text { Applies a percentage margin to all } \\
\text { costs including hardware, installation } \\
\text { labor, EPC overhead, and developer } \\
\text { overhead }\end{array}$ & NREL 2021 \\
\hline
\end{tabular}

We use these inputs to calculate energy storage cost via the following equation ${ }^{17}$ :

$$
\text { Energy storage installation cost }\left(\frac{\$}{k W h}\right)=
$$

Battery cost $\left(\frac{\$}{k W h}\right)+\frac{\text { Other cost components }(\$) \text { such as battery inverter and labor }}{\text { Storage system size }(k W) \times \text { Duration }(\text { hours })}$

\footnotetext{
${ }^{17}$ This equation is only for the energy storage installation cost calculation. For LCOS, the equation would be different. LCOS is not covered in this report.
} 
Figure 22 shows the resulting nameplate and usable costs for $60-\mathrm{MW} \mathrm{Li-ion} \mathrm{energy} \mathrm{storage}$ systems, which vary from $\$ 379 / \mathrm{kWh}_{\text {usable }}$ (4-hour duration) to $\$ 907 / \mathrm{kWh}_{\text {usable }}(0.5$-hour duration). Though the per-energy-unit battery cost increases as system duration decreases, the total battery cost - and the proportion of the cost attributed to the battery-decrease as system duration decreases. For example, the battery cabinet cost accounts for $58 \%$ of total system cost in the 4 -hour system but only $33 \%$ in the 0.5 -hour system. At the same time, non-battery cost categories account for an increasing proportion of the system cost as duration declines.

$\$ 1,000 \quad 2020$ USD \$/kWh

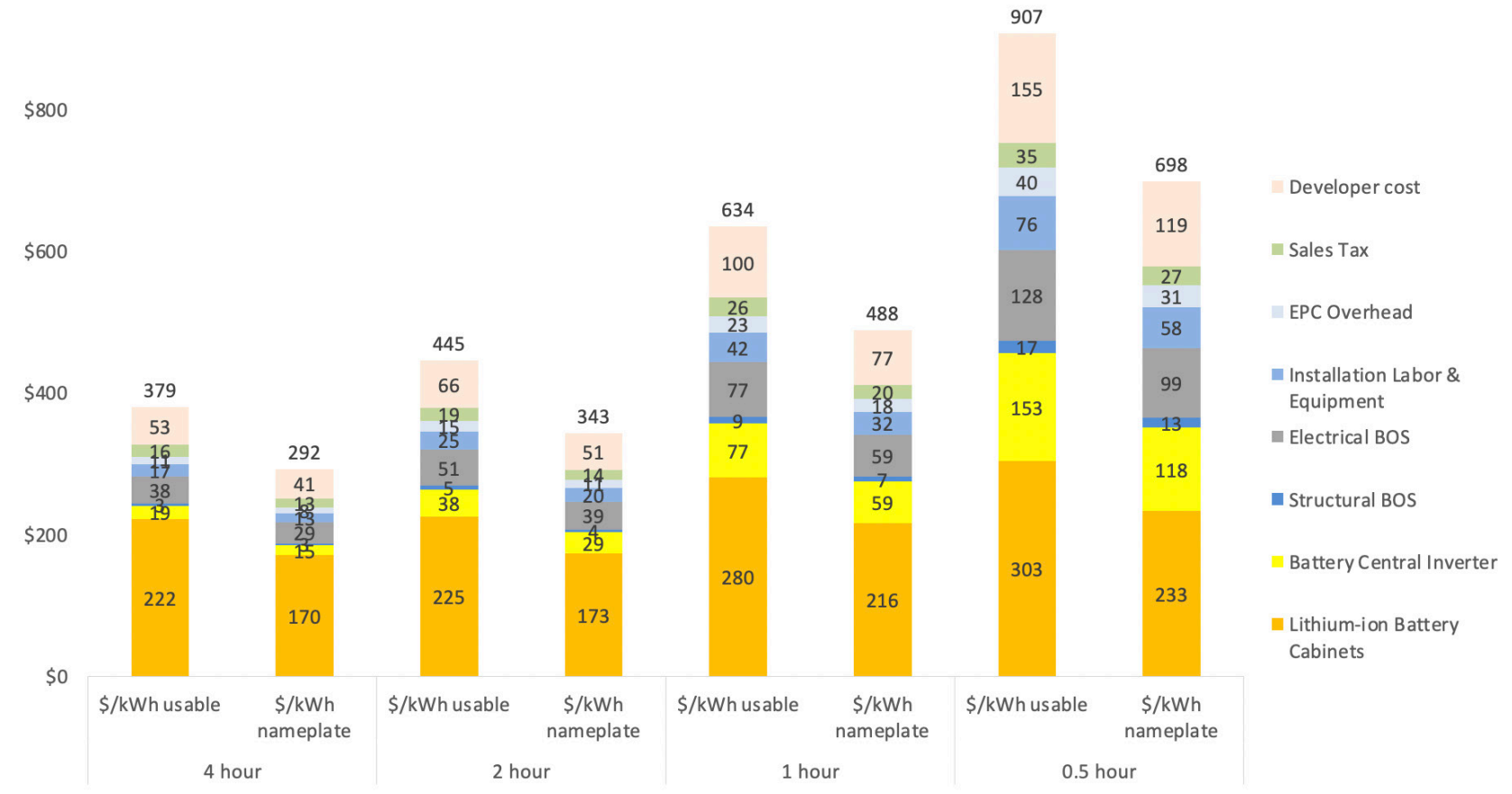

Figure 22. U.S. utility-scale Li-ion battery stand-alone storage costs for durations of $0.5-4.0$ hours $\left(60 M W_{D C}\right), Q 12021$

\subsection{PV-Plus-Storage System Cost Model}

Here we combine our energy storage cost model with our PV system cost model in various configurations, including (1) hybrid PV-plus-storage systems versus PV and storage systems located in different places and (2) DC-coupled versus AC-coupled battery configurations for the hybrid PV-plus-storage systems. As shown in Table 9, hybridization enables sharing of several hardware components by the PV and energy storage systems, which can reduce costs. Hybridization can also reduce soft costs related to site preparation; land acquisition; permitting and interconnection; installation labor; and EPC/developer overhead and profit. 
Table 9. Cost Factors for Siting PV and Storage Together versus Separately

\begin{tabular}{|c|c|c|}
\hline Model Component & Hybrid PV-plus-Storage & $\begin{array}{l}\text { PV and Storage at } \\
\text { Different Sites }\end{array}$ \\
\hline Site preparationa & Once & Twice \\
\hline Land acquisition cost & Lower & Higher \\
\hline $\begin{array}{l}\text { Hardware sharing between PV } \\
\text { and energy storage }\end{array}$ & $\begin{array}{l}\text { Yes (step-up transformer, switchgear, monitor, } \\
\text { and controls) }\end{array}$ & No \\
\hline Installation labor cost & $\begin{array}{l}\text { Lower (due to hardware sharing and single labor } \\
\text { mobilization) }\end{array}$ & Higher \\
\hline $\begin{array}{l}\text { EPC/developer overhead } \\
\text { and profit }\end{array}$ & $\begin{array}{l}\text { Lower (due to lower labor cost, BOS, and total } \\
\text { system cost) }\end{array}$ & Higher \\
\hline Interconnection and permitting & Once & Twice \\
\hline
\end{tabular}

a Site preparation is a subcategory of labor cost, so it is not shown in the cost breakdown chart.

When PV and battery storage are colocated, the subsystems can be connected in either a DCcoupled or an AC-coupled configuration (Figure 23). A DC-coupled system built using a bidirectional inverter connects battery storage directly to the PV array via DC-DC converters. In contrast, an AC-coupled system needs both a PV inverter and a bidirectional inverter, and there are multiple conversion steps between DC and AC to charge or discharge the battery. The bidirectional inverter used in both DC-coupled and AC-coupled configurations enable grid charging capabilities. Also, it should be noted that the transmission line could be used for both PV and battery storage systems. Hybrid PV-plus-battery systems that are charged by the PV system more than $75 \%$ of the time on an annual basis for the first 5 years of a project are eligible for the federal investment tax credit.

Reasons an installer or a developer may pursue a DC-coupled system include:

1. Installing a DC-coupled system with a single bidirectional inverter ${ }^{18}$ (Table 10. , page 39) reduces additional costs for the inverter, inverter wiring, and inverter housing.

2. DC-coupled systems mitigate extra conversion of energy from DC to AC to DC, and so they have higher RTE than AC-coupled systems. However, as power electronics are becoming more efficient, the actual efficiency difference is becoming smaller (Enphase 2019).

3. Because the battery is connected directly to the PV system via DC-DC converter, excess PV generation that falls outside the inverter limits can be sent directly to the battery and thus lead to an increase in overall output for the same interconnection capacity (DiOrio and Hobbs 2018).

18 DC-coupled systems could use a unidirectional inverter as well, but that configuration is not considered in our cost modeling. This configuration could lead to lower total system installed cost than a DC-coupled system using a bidirectional inverter but at the same time it prevents the system from grid charging. 
4. A DC-coupled system has only one point of interconnection, reducing interconnection complexity, time, and associated cost.
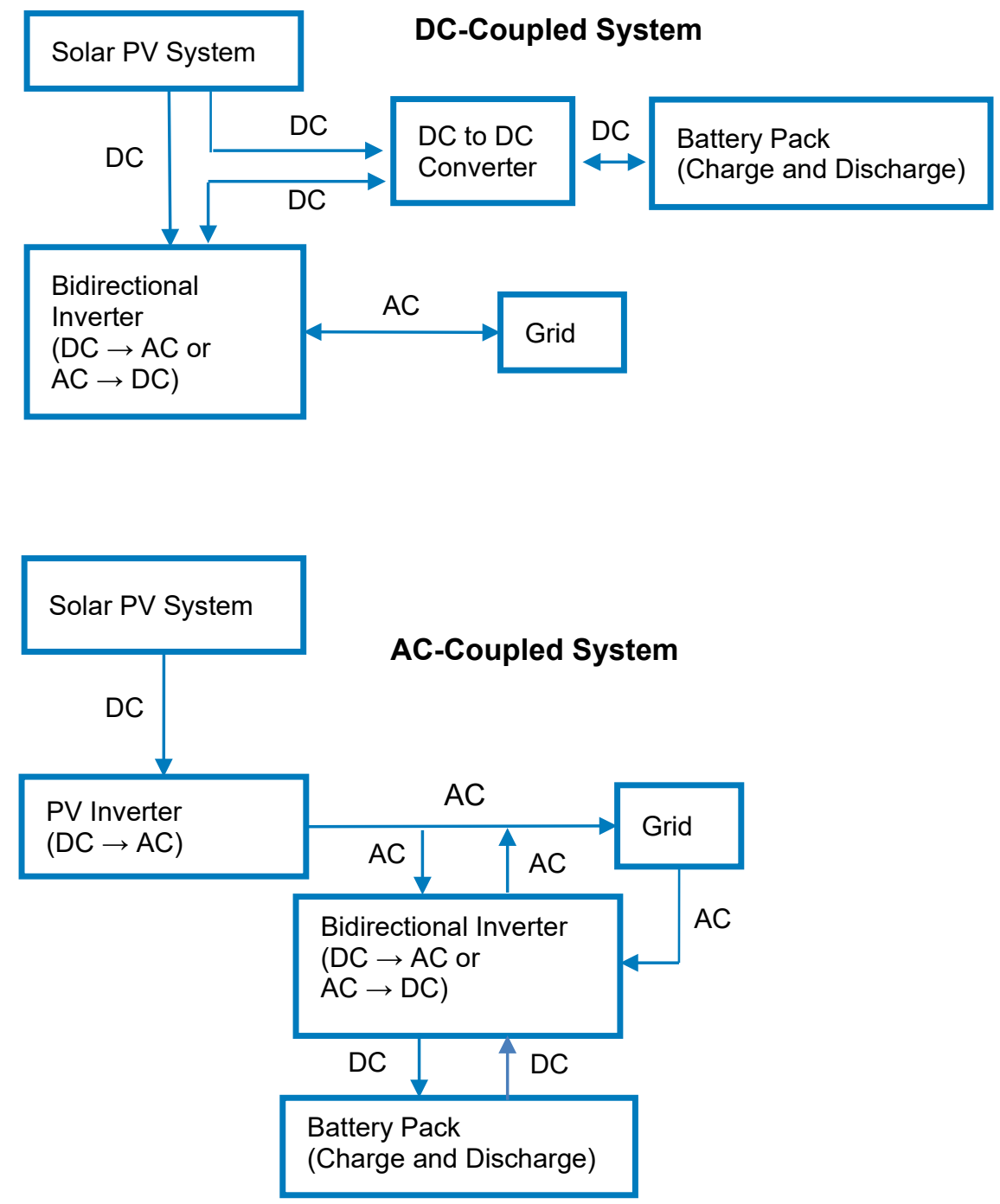

Figure 23. DC-coupled and AC-coupled PV-plus-storage system configurations 
Table 10. Comparison of DC- and AC-Coupling for Utility-Scale PV-plus-Storage Systems

\begin{tabular}{lll} 
Model Component & DC-Coupled Configuration & AC-Coupled Configuration \\
\hline Number of inverters & 1 (bidirectional inverter for battery) & $\begin{array}{l}2 \text { (bidirectional inverter for battery plus } \\
\text { grid-tied inverter for PV) }\end{array}$ \\
\hline Electrical BOS & $\begin{array}{l}\text { Less (but needs additional DC-to-DC } \\
\text { converters) }\end{array}$ & $\begin{array}{l}\text { More (due to additional wiring } \\
\text { for inverters) }\end{array}$ \\
\hline Installation labor cost & $\begin{array}{l}\text { More (due to additional DC-DC } \\
\text { converters and more skilled labor and } \\
\text { labor hours required for DC work) }\end{array}$ & Less (better labor mobilization) \\
\hline EPC overhead & $\begin{array}{l}\text { More (due to higher installation } \\
\text { labor cost) }\end{array}$ & Less \\
\hline Sales tax & Less & $\begin{array}{l}\text { More (due to higher total } \\
\text { hardware costs) }\end{array}$ \\
\hline EPC/developer profit & Less & $\begin{array}{l}\text { More (due to higher total EPC and } \\
\text { developer costs) }\end{array}$ \\
\hline
\end{tabular}

The advantages of the AC-coupled system include the following:

1. For a retrofit project (i.e., the addition of battery storage to an existing PV array), an ACcoupled battery may be more practical than a DC-coupled battery, because existing PV system may not need to be redesigned. Thus, the additional costs that are due to replacing the inverter and rewiring the system could make retrofit costs higher for a DC-coupled system than for an AC-coupled system (Ardani et al. 2017).

2. Because AC-coupled systems have independent PV and battery systems with separate inverters, this hybrid configuration enables redundancy. For instance, if the battery-based inverter fails to operate, the PV system could operate independently as long as the grid is up.

\subsection{Model Output}

Figure 24 summarizes our model results for several system types and configurations:

- Stand-alone $100-\mathrm{MW}_{\mathrm{DC}} \mathrm{PV}$ system with one-axis tracking (\$89 million)

- Stand-alone 60-MW $\mathrm{DC}_{\mathrm{DC}} / 240-\mathrm{MWh}$ Usable, 4-hour-duration energy storage system ( $\$ 90$ million $^{19}$ )

- $\quad$ DC-coupled PV (100-MW $\left.W_{D C}\right)$ plus storage (60-MW $\mathrm{M}_{\mathrm{D} / \mathrm{AC}} / 240-\mathrm{MWh}_{\text {Usable, }}$ 4-hour-duration) system (\$168 million)

\footnotetext{
${ }^{19}$ The total cost of a stand-alone utility-scale energy storage system with a power rating of $\mathrm{P}(\mathrm{kW})$ and storage duration $\mathrm{H}(\mathrm{hrs})$ can also be represented using the following linear equation:
}

Total System Cost $=\$ 311.28 * \mathrm{P}+\$ 300.24 * \mathrm{P} * \mathrm{H}$ with an $\mathrm{R}$ squared value of 99.8 . 
- $\quad$ AC-coupled PV (100-MW $\left.{ }_{\mathrm{DC}}\right)$ plus storage (60-MW $\mathrm{M}_{\mathrm{D} / \mathrm{AC}} / 240-\mathrm{MWh}_{\text {Usable, }}$ 4-hour-duration) system (\$167 million)

- PV (100-MW DC $_{\text {) }}$ and storage (60-MW $\mathrm{D} / \mathrm{AC} / 240-\mathrm{MWh}$ Usable, 4-hour-duration) systems sited in different locations (\$179 million).

Colocating the PV and storage subsystems produces cost savings by reducing costs related to site preparation; land acquisition; permitting and interconnection; installation; labor; hardware (via sharing of hardware such as switchgears, transformers, and controls); overhead; and profit. The cost of the hybrid systems is $6 \%-7 \%$ lower than the cost of the system with PV and storage sited separately.

Between DC-coupling and AC-coupling, total costs vary by a smaller percentage, as the cost differences between DC-coupling and AC-coupling in the categories of solar inverter, structural BOS, electrical BOS, labor, EPC and developer overhead, sales tax, contingency, and profit offset each other. For an actual project, however, cost savings may not be the only factor in choosing DC- or AC-coupling; additional factors - such as retrofit considerations, system performance (including energy loss that is due to clipping), design flexibility, and O\&M-should be considered.

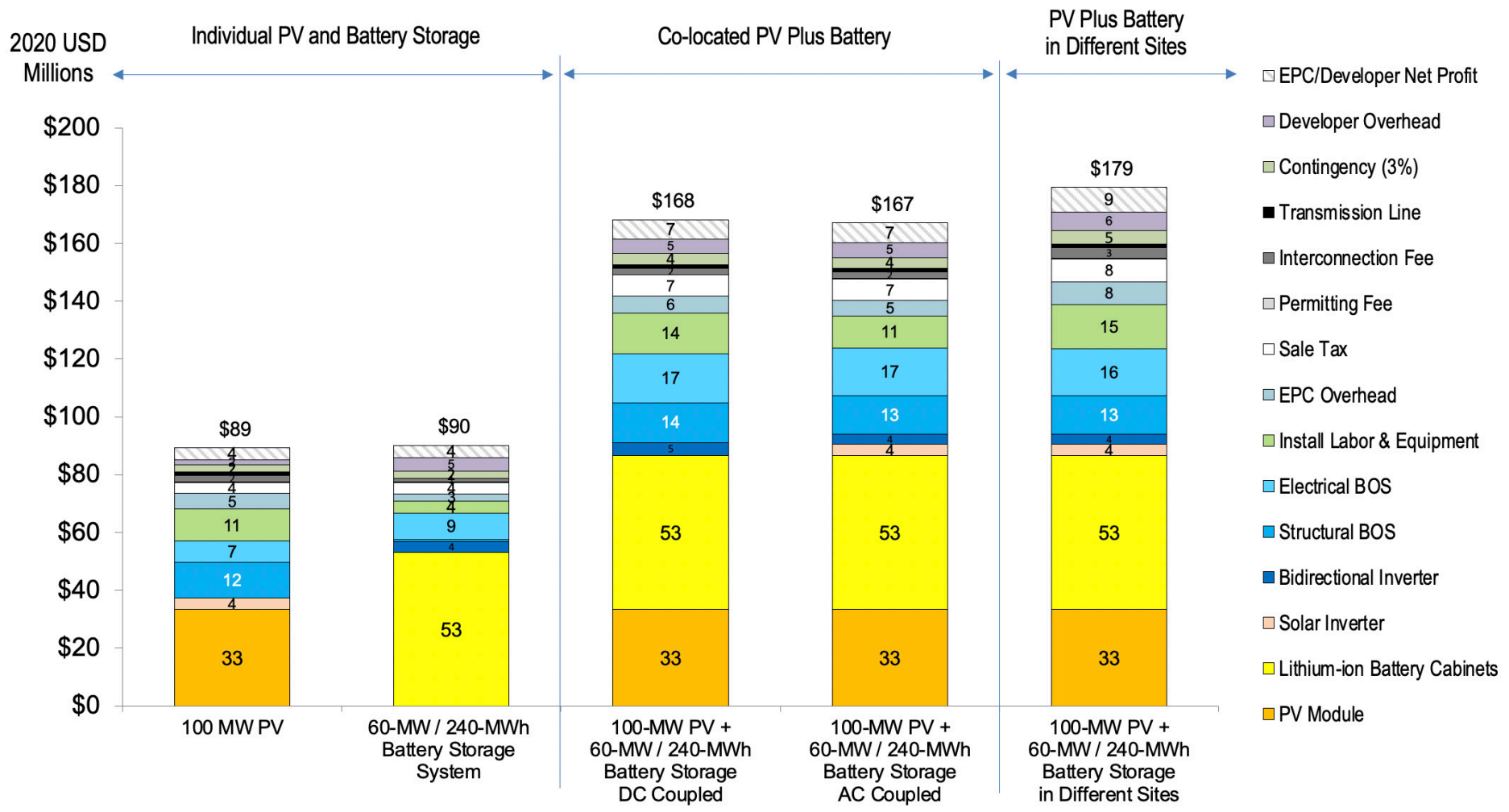

Figure 24. Cost benchmark for Utility PV-plus-storage systems (4-hour duration) in different sites and the same site (DC-coupled and AC-coupled cases), Q1 2021 


\section{Operation and Maintenance}

Benchmark PV operation and maintenance (O\&M) costs are estimated using a PV O\&M cost model (Walker et al. 2020) that provides a line-item cost estimate of measures that correspond to the PV O\&M services described in Best Practices for Operation and Maintenance of Photovoltaic and Energy Storage Systems, 3rd Edition (NREL et al. 2018); O\&M cost drivers for PV modules and inverters in the model are informed by actuarial failure and repair data from Sandia National Laboratories (Klise, Lavrova, and Gooding 2018), but current default values for other measures that occur on fixed intervals or for which the failure rate data are unavailable reflect the best judgement of a Solar Energy Technologies Office-sponsored working group. ${ }^{20}$

In the current version of the model, the analysis period, labor rates for 2020 , the module and inverter replacement cost, discount rate, inflation rate, capital expenditures, module power and efficiency, degradation rates, warranty period, cost of aerial inspection are adjusted for this Fiscal Year (FY) 21 update. Actuarial failure and repair data are not updated in this version from the last year. Of five additional line measures (land lease, property taxes, insurance, asset management, and security) that were added last year based on the feedback collected by Lawrence Berkeley National Laboratory from U.S. solar industry professionals (Wiser, Bolinger, and Seel 2020), only the insurance line item is updated in this version. In this round of revision, some of the 133 line measures are deleted if they were either dated or not applicable to certain type of systems, especially residential and utility systems (one-axis tracking), based on highlevel market research.

The FY 20 benchmark O\&M costs included PV module cleaning and several types of inspections in the residential case, and these costs are removed from the FY21 benchmarks because residential cleaning is often not recommended and inspections of residential systems are uncommon. Vegetation and pest control remain as annual costs in the FY21 benchmark for residential PV system O\&M.

Addition of insurance costs increases annual cost substantially in this FY 2021 update. Different types of insurances that may be needed by a PV plant operator are listed in Insurance in the Operation of Photovoltaic Plants (Schwab, Walker, and Desai 2020). Two major categories of insurance are (1) property insurance, which insures the PV plant hardware against hazards and (2) liability insurance, which insures against claims of harm by others. Property insurance is included in the benchmark insurance cost because it can be associated with a single PV plant whereas liability and other types of insurance (e.g., commercial vehicle and workers'

\footnotetext{
${ }^{20}$ The Solar Access to Public Capital (SAPC) Working Group was convened in 2014 to open capital market investment in the solar asset class and consisted of solar developers, financiers and capital managers, law firms, rating agencies, accounting and engineering firms, and other stakeholders engaged in solar asset deployment. In 2016, a subset of the SAPC Working Group was merged with Sandia National Laboratories' Technical O\&M Working Group to unify efforts by the U.S. Department of Energy (DOE) to improve O\&M practices, data standards, and costs. This combined body - the PV O\&M Working Group - is administrated by the National Renewable Energy Laboratory (NREL), Sandia National Laboratories, SunSpec Alliance, and Roger Hill, and it is supported by the DOE SunShot Initiative (SuNLaMP program)..
} 
compensation insurance) are often written as an umbrella policy to cover exposure of a company rather than a PV plant. Note that these other types of insurance (i.e., other than property insurance) may be substantial, even though they are not included in this per-PV-plant benchmark cost.

The property insurance premium is estimated as a fraction multiplied by the replacement value for which the plant is insured; as a proxy for replacement value, we use the benchmark capital cost of the PV plant as the premium basis. For residential systems, the factor may vary from 0.004 to 0.006 and for benchmark value we use $0.00454^{21}$ times capital cost per year, which translates to $\$ 12.03 / \mathrm{kW} / \mathrm{yr}$. For commercial and utility-scale plants, the factor varies a lot, from 0.0015 to 0.009 depending on hazards in an area and the extent of coverages, and we use benchmark value of $0.0025^{22}$ times capital cost per year for property insurance (escalated each year for inflation and discounted for a levelized cost). This translates to a range of \$2.06$\$ 12.37 / \mathrm{kW} /$ year, and a benchmark value of $\$ 3.44 / \mathrm{kW} / \mathrm{yr}$. for a $200-\mathrm{kW}$ commercial rooftop system and $\$ 1.17-\$ 7.02 / \mathrm{kW} /$ year, and a benchmark value of $\$ 1.95 / \mathrm{kW} / \mathrm{yr}$. for a $100 \mathrm{MW}$ utilityscale single-axis tracking system.

Microinverters are assumed for residential systems and DC optimizers (three-phase) are assumed for commercial roof-mounted PV systems. A commercial roof-mounted string inverter with a 12year warranty incurs slightly more replacement cost than a residential roof-mounted microinverter with a 25-year warranty. Also, the analysis period is 30 years for the commercial system and 25 years for the residential system; because of its longer lifetime, the commercial roofmounted PV project owners will need to repair the inverter more often and the inverters are more likely to be out of the warranty period.

O\&M costs in the PV O\&M cost model include preventative maintenance, scheduled at regular intervals with costs increasing at the rate of general inflation, as well as corrective maintenance to replace components. The model derives corrective maintenance by multiplying the replacement cost, including labor, by the probability that a failure will occur each year based on actuarial data. Component failure probabilities for each year are calculated using a Weibull, lognormal, or other distribution based on actual data, when possible (Gunda and Homan 2020).

As shown in Figure 25, the measures in the cost model are sorted into inverter replacement, operations, module and components replacement, inspection, monitoring, PV module cleaning, vegetation and pest control, land lease, property taxes, insurance, asset management, and security. The current benchmark are $\$ 28.97 / \mathrm{kW}_{\mathrm{DC}} / \mathrm{yr}$ (residential), $\$ 17.92 / \mathrm{kW}_{\mathrm{DC}} / \mathrm{yr}$ (commercial; roof-mounted), $\$ 17.10 / \mathrm{kW}_{\mathrm{DC}} / \mathrm{yr}$ (commercial; ground-mounted), $\$ 14.61 / \mathrm{kW}_{\mathrm{DC}} / \mathrm{yr}$ (utility-scale, fixed-tilt), and $\$ 16.06 / \mathrm{kW}_{\mathrm{DC}} / \mathrm{yr}$ (utility-scale, single-axis tracking).

21 Luke Ortgessen, Country Companies, August 1, 2021

22 Sara Cane, CAC Specialty Insurance, August 3, 2021 


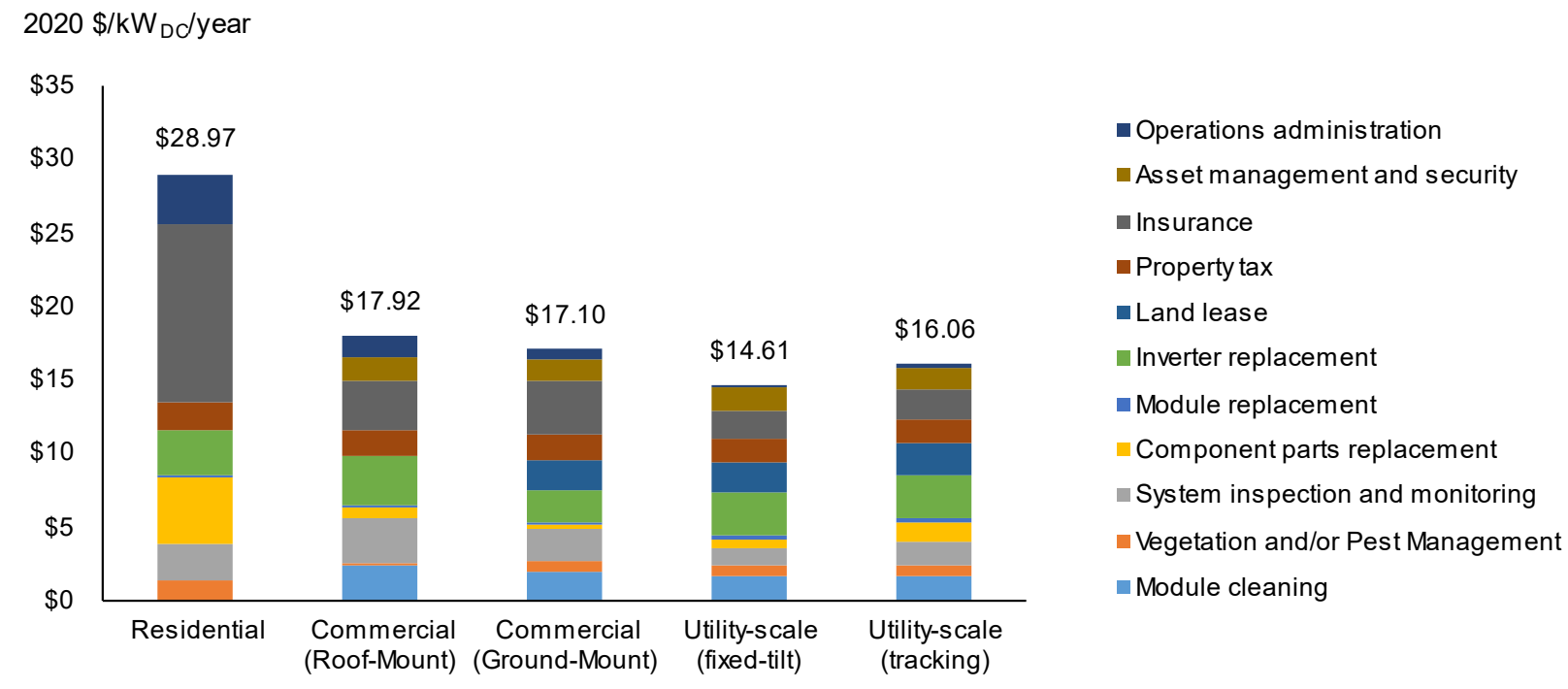

Figure 25. Q1 2021 residential, commercial, and utility-scale O\&M costs by category

As stated previously, the values in Figure 25 represent line-item estimates of costs associated with best practices, and therefore actual costs may vary. For example, in a residential system, a homeowner may not increase the coverage of their property insurance after they get a system and avoid such costs (saving money if no damages occur to the PV system but putting themselves at risk if any damages occur). Additionally, we put a value on the time of a homeowner (i.e., "operations administration"), even though they are not getting paid for their activities. Therefore, a homeowner may only perceive O\&M costs of $\$ 13.46 / \mathrm{kW} / \mathrm{yr}$., however they are likely underinsuring against risk and not properly taking into account the efforts of maintaining a PV system on their home. 


\section{LCOE of Stand-Alone PV and PV-Plus-Storage Systems}

Although LCOE is an imperfect metric to measure the competiveness of PV within the energy marketplace, it does incorporate many PV metrics - beyond upfront installation costs - that are important to energy costs. Similar to the LCOE of stand-alone PV systems, the LCOE of PVplus-storage does not focus on value of electricity but rather can help track improvements to all costs of a PV-plus-storage system over time (as opposed to just upfront costs), and the metric can provide limited comparisons with other dispatchable electricity generation technologies (e.g., natural gas).

We updated some assumptions from the previous edition of this report (Feldman et al. 2021) using ongoing NREL benchmarking work, and we kept all other values the same. We input PV stand-alone system assumptions into NREL's System Advisor Model, a performance and financial model, ${ }^{23}$ to calculate real LCOEs (considering inflation) for various locations. We input PV-plus-storage system assumptions into the LCOE equation for PV-plus-storage (LCOSS) we derived from last year's report (Feldman et al. 2021). The LCOE equation for PV-plus-storage system can be found in Appendix B. In this year's report, we calculate LCOE assuming longterm steady-state financing assumptions, with no investment tax credit and with interest rates higher than current historically low levels.

Table 11 lists our model input assumptions for calculating LCOE of stand-alone PV and Table 12 lists our model input assumptions for calculating LCOE of PV-plus-storage.

${ }^{23}$ See “System Advisor Model (SAM),” NREL, https://sam.nrel.gov/. 
Table 11. LCOE (Stand-Alone PV) Input Assumptions and Outputs (2020 USD)

\begin{tabular}{|c|c|c|c|c|c|c|}
\hline & \multicolumn{2}{|c|}{ Residential } & \multicolumn{2}{|c|}{ Commercial Rooftop } & \multicolumn{2}{|c|}{ One-Axis Tracker } \\
\hline & 2020 & 2021 & 2020 & 2021 & 2020 & 2021 \\
\hline Installed cost $(\$ / W)$ & 2.74 & 2.65 & 1.74 & 1.56 & 1.02 & 0.89 \\
\hline Annual degradation (\%) & 0.70 & 1.00 & 0.70 & 0.70 & 0.70 & 0.70 \\
\hline Levelized O\&M expenses over life of asset (\$/kW-yr) & 29 & 29 & 19 & 18 & 18 & 16 \\
\hline Preinverter derate $(\%)$ & 90.5 & 85.9 & 90.5 & 85.9 & 90.5 & 85.9 \\
\hline Inverter efficiency (\%) & 98.0 & 96.0 & 98.0 & 96.0 & 98.0 & 96.0 \\
\hline Inverter loading ratio & 1.15 & 1.15 & 1.15 & 1.15 & 1.34 & 1.28 \\
\hline Inflation rate $(\%)$ & 2.5 & 2.5 & 2.5 & 2.5 & 2.5 & 2.5 \\
\hline Equity discount rate (real) (\%) & 6.1 & 10.2 & 6.1 & 6.1 & 5.1 & 5.1 \\
\hline Debt interest rate $(\%)$ & 5.0 & 4.5 & 5.0 & 5.0 & 5.0 & 5.0 \\
\hline Debt fraction (\%) & 71.8 & 100 & 71.8 & 71.8 & 71.8 & 71.8 \\
\hline Debt term (years) & 18 & 25 & 18 & 18 & 18 & 18 \\
\hline Entity & Corporation & Homeowner & Corporation & Corporation & Corporation & Corporation \\
\hline Analysis period (years) & 30 & 25 & 30 & 30 & 30 & 30 \\
\hline Initial energy yield $\left(\mathbf{k W h} / \mathbf{k W}_{\mathrm{DC}}\right)$ & 1,546 & 1,445 & 1,440 & 1397 & 1,721 & 1,694 \\
\hline Real LCOE (2020 US\$) & $13.0 \phi / \mathrm{kWh}$ & $11.9 \phi / k W h$ & $9.1 \phi / \mathrm{kWh}$ & $8.3 \phi / \mathrm{kWh}$ & $4.6 \phi / \mathrm{kWh}$ & 4.1ф/kWh \\
\hline
\end{tabular}

Other key assumptions:

(1) Corporation has a federal corporate tax rate of $21 \%$ and state corporate tax rate of $6 \%$, and uses the Modified Accelerated Cost Recovery System depreciation schedule.

(2) Homeowner uses a mortgage loan that is interest deductible, with a federal personal tax rate of $15 \%$ and a personal state tax rate of $6 \%$.

(3) No state or local subsidies

(4) For corporations:

- a working capital and debt service reserve account for six months of operating costs and debt payments (earning an interest rate of $1.75 \%$ )

- a six-month construction loan, with an interest rate of $4 \%$ and a fee of $1 \%$ of the cost of the system

- $\$ 1.1$ million of upfront financial transaction costs for a $\$ 100$ million third-party ownership transaction of a pool of commercial projects 
(5) 2020 capacity factors are based on Kansas City, Missouri, with a tilt/azimuth of 25/180 (residential), 10/180 (commercial rooftop), and tracking/180 (utility-scale). 2021 capacity factors are based on Fredonia, Kansas (which is near the geographic center of the 48 conterminous states and corresponds with the area-weighted capacity factor of the 48 conterminous states as outlined in the 2021 Annual Technology Baseline), with a tilt/azimuth of 20/214 (residential) (Barbose et al. 2020), 10/190 (commercial rooftop) (Barbose et al. 2020), and tracking/180 (utility-scale).

\section{Table 12. LCOE (PV-plus-storage) Input Assumptions and Outputs (2020 USD)}

\begin{tabular}{|c|c|c|c|c|c|c|}
\hline & \multicolumn{2}{|c|}{$\begin{array}{l}\text { Residential } \\
\text { 22-panel PV plus 5-kW/12.5-kWh } \\
\text { storage system }^{24}\end{array}$} & \multicolumn{2}{|c|}{$\begin{array}{l}\text { Commercial } \\
\text { 1-MW fixed-tilt ground-mounted PV } \\
\text { plus } 600-k W / 2.4-M W h \text { storage } \\
\text { system }\end{array}$} & \multicolumn{2}{|c|}{$\begin{array}{l}\text { Utility-scale } \\
\text { 100-MW one-axis tracker PV plus } \\
60-M W(240-M W h) \text { battery storage, } \\
\text { AC-coupled }\end{array}$} \\
\hline & 2020 & 2021 & 2020 & 2021 & 2020 & 2021 \\
\hline Installed cost $(\$)$ & $\$ 34,942$ & $\$ 30,450$ & $\$ 2,170,851$ & $\$ 1,970,000$ & $\$ 190$ million & $\$ 167$ million \\
\hline Annual degradation (\%) & 0.70 & 1.00 & 0.70 & 0.70 & 0.70 & 0.70 \\
\hline $\begin{array}{l}\text { Levelized O\&M expenses over } \\
\text { life of asset }(\$ / \mathrm{kW}-\mathrm{yr})\end{array}$ & 39 & 39 & 29 & 28 & 28 & 26 \\
\hline $\begin{array}{l}\text { First follow-on investments } \\
\text { (inverter, battery } \\
\text { replacements) (\$) }\end{array}$ & $\$ 865$ & $\$ 763$ & $\$ 80,439$ & $\$ 63,360$ & $\$ 8.0$ million & $\$ 6.3$ million \\
\hline $\begin{array}{l}\text { Second follow-on investments } \\
\text { (inverter, battery } \\
\text { replacements) }(\$)\end{array}$ & $\$ 648$ & $\$ 572$ & $\$ 60,329$ & $\$ 47,520$ & $\$ 6.0$ million & $\$ 4.8$ million \\
\hline Preinverter derate $(\%)$ & 90.5 & 85.9 & 90.5 & 85.9 & 90.5 & 85.9 \\
\hline Inverter efficiency (\%) & 98.0 & 96.0 & 98.0 & 96.0 & 98.0 & 96.0 \\
\hline Inverter loading ratio & 1.15 & 1.15 & 1.15 & 1.15 & 1.34 & 1.28 \\
\hline Inflation rate $(\%)$ & 2.5 & 2.5 & 2.5 & 2.5 & 2.5 & 2.5 \\
\hline Equity discount rate (real) (\%) & 6.1 & 10.2 & 6.1 & 6.1 & 5.1 & 5.1 \\
\hline
\end{tabular}

${ }^{24}$ The current version of our residential PV-plus-storage model assumes a battery size of $5 \mathrm{~kW} / 12.5 \mathrm{kWh}$; the Q1 2020 benchmark models a battery size of $3 \mathrm{~kW}(6 \mathrm{kWh})$ (Feldman et al. 2021). To better distinguish the historical cost trends from the changes to our cost models, we calculate the Q1 2020 residential PV-plus-storage using a battery size of $5 \mathrm{kWh}(12.5 \mathrm{kWh})$. For this reason, CAPEX $(2020 \mathrm{USD} 28,721)$ and LCOE $(20.1 \mathrm{USD}$ cents/kWh) differ from those reported in Table 12, adjusting for dollar year. 


\begin{tabular}{|c|c|c|c|c|c|c|}
\hline & \multicolumn{2}{|c|}{$\begin{array}{l}\text { Residential } \\
\text { 22-panel PV plus 5-kW/12.5-kWh } \\
\text { storage system }^{24}\end{array}$} & \multicolumn{2}{|c|}{$\begin{array}{l}\text { Commercial } \\
\text { 1-MW fixed-tilt ground-mounted PV } \\
\text { plus } 600-\mathrm{kW} / 2.4-\mathrm{MWh} \text { storage } \\
\text { system }\end{array}$} & \multicolumn{2}{|c|}{$\begin{array}{l}\text { Utility-scale } \\
\text { 100-MW one-axis tracker PV plus } \\
\text { 60-MW (240-MWh) battery storage, } \\
\text { AC-coupled }\end{array}$} \\
\hline & 2020 & 2021 & 2020 & 2021 & 2020 & 2021 \\
\hline Debt interest rate (\%) & 5.0 & 4.5 & 5.0 & 5.0 & 5.0 & 5.0 \\
\hline Debt fraction (\%) & 71.8 & 100 & 71.8 & 71.8 & 71.8 & 71.8 \\
\hline Debt term (years) & 18 & 25 & 18 & 18 & 18 & 18 \\
\hline Entity & Corporation & Homeowner & Corporation & Corporation & Corporation & Corporation \\
\hline Analysis period (years) & 30 & 25 & 30 & 30 & 30 & 30 \\
\hline $\begin{array}{l}\text { Initial energy yield } \\
\text { (kWh/kW } k \text { DC) }\end{array}$ & 1,546 & 1,445 & 1,440 & 1397 & 1,721 & 1,694 \\
\hline Real LCOE (2020 US\$) & $23.3 \phi / \mathrm{kWh}$ & $20.5 \phi / \mathrm{kWh}$ & $12.1 \phi / \mathrm{kWh}$ & $11.4 \phi / k W h$ & $8.8 \phi / k W h$ & $7.7 \phi / k W h$ \\
\hline
\end{tabular}

Other key assumptions:

(1) Corporation has a federal corporate tax rate of $21 \%$ and state corporate tax rate of $6 \%$, and uses the Modified Accelerated Cost Recovery System depreciation schedule.

(2) Homeowner uses a mortgage loan that is interest deductible, with a federal personal tax rate of $15 \%$ and a personal state tax rate of $6 \%$.

(3) No state or local subsidies

(4) For corporations:

- a working capital and debt service reserve account for six months of operating costs and debt payments (earning an interest rate of $1.75 \%$ )

- a six-month construction loan, with an interest rate of $4 \%$ and a fee of $1 \%$ of the cost of the system

- $\$ 1.1$ million of upfront financial transaction costs for a $\$ 100$ million third-party ownership transaction of a pool of commercial projects

(5) 2020 PV capacity factors are based on Kansas City, Missouri, with a tilt/azimuth of 25/180 (residential), 10/180 (commercial rooftop), and tracking/180 (utility-scale). 2021 capacity factors are based on Fredonia, Kansas (which is near the geographic center of the 48 conterminous states and corresponds with the area-weighted capacity factor of the 48 conterminous states as outlined in the 2021 Annual Technology Baseline), with a tilt/azimuth of 20/214 (residential) (Barbose et al. 2020), 10/190 (commercial rooftop) (Barbose et al. 2020), and tracking/180 (utility-scale).

(6) Round-trip energy losses from PV/battery/grid: $10 \%$; round-trip energy losses from grid/battery/grid ( $8 \%$ )

(7) Battery is charged solely by PV because of investment tax credit considerations. 
Figure 26 compares LCOE, by market segment, for the current and previous benchmark analyses. From 2020 to 2021, residential PV-plus-storage LCOE fell 13\%, ${ }^{25}$ and residential stand-alone-PV LCOE fell $9 \%$; there were $7 \%$ and $13 \%$ reductions in levelized electricity costs for commercial and utility-scale PV-plus-storage systems. At the same time, LCOE of commercial and utility scale stand-alone PV systems fell by $9 \%$ and $12 \%$ respectively. The reduction in electricity costs were mostly due to changes in CAPEX and OPEX (operating expenditures), though residential PV LCOE and PV-plus-storage LCOE also fell due to changes in financial model assumptions. ${ }^{26}$ The reductions were partially counterbalanced by a change in capacity factor assumptions that reduced system performance to better align with U.S. averages. ${ }^{27}$

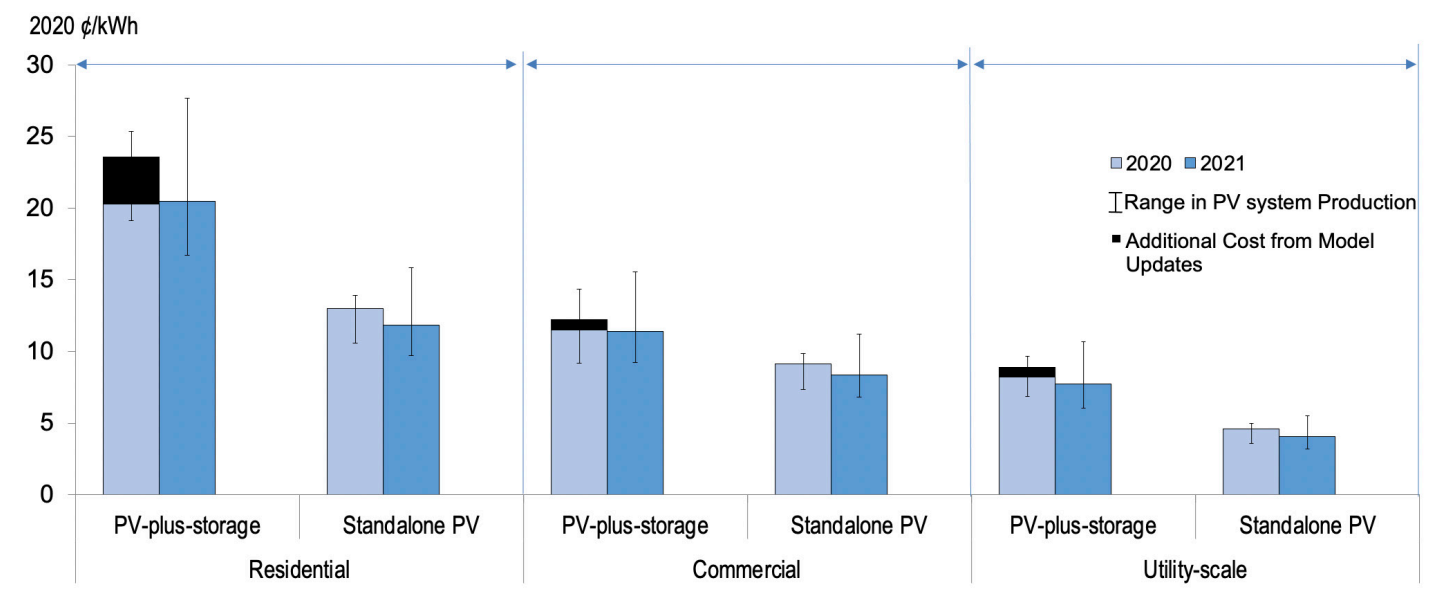

Figure 26. LCOE 2020-2021

${ }^{25}$ Reported 2021 residential PV plus storage LCOE values are 17\% higher than 2020 values because the 2021 report models a larger battery system $(5 \mathrm{~kW} ; 12.5 \mathrm{kWh})$ than the 2020 benchmark report $(3 \mathrm{~kW} / 6 \mathrm{kWh})$. When using $2020 \mathrm{PV}$ plus storage LCOE model assumptions, the 2020 value rises from $20.1 \phi / \mathrm{kWh}$ to $21.5 \phi / \mathrm{kWh}$.

${ }^{26}$ In this year's report, we change residential financial assumption from a third-party-ownership model to one in which homeowners finance the cost of a system through their mortgage. The percentage of host-owned PV systems has increased substantially over the past 5 years (63\% of residential PV systems in 2019), and most of these use a personal loan. Though mortgages are not currently the most prevalent source of funding, they represent a major opportunity for cost reductions for PV system costs, and therefore we view this as reasonable long-term steady-state financing assumption. Because of hostownership, we assume the homeowner does not spend as much time or effort on maintaining the PV system as a third party and therefore O\&M cost are reduced, while degradation rate increases, and system lifetime decreases.

${ }^{27}$ Capacity factor assumptions in this year's report were changed to better correspond with U.S. national averages and be more in line with updates made in the 2021 Annual Technology Baseline. It uses county-level capacity factor averages, weighted by usable land area (utility-scale) or population (residential and commercial). Tilt and azimuth assumptions were also changed to correspond with national average reported by Barbose et al. (2020). Also, we adjusted the preinverter derate (DC losses) and inverter efficiency (AC losses) to better correspond with default assumptions in other NREL modeling applications. 
The current versions of our residential PV-plus-storage model assumes a battery size of $5 \mathrm{~kW} / 12.5 \mathrm{kWh}$; the Q1 2020 benchmark modeled a battery size of $3 \mathrm{~kW}$ (6 kWh) (Feldman et al. 2021). To better distinguish the historical cost trends from the changes to our cost models, we also calculate the Q1 2020 residential PV-plus-storage using a battery size of $5 \mathrm{kWh}$ (12.5 kWh). The Additional Costs from Model Updates category represents the difference between modeled results (3 kW/6 kWh: $20.1 \phi / \mathrm{kWh} ; 5 \mathrm{~kW} / 12.5 \mathrm{kWh}: 21.5 \phi / \mathrm{kWh})$. LCOE is calculated for each scenario under a range of capacity factors, but all other values remain the same. The locations used in the 2021 benchmarks for high and low solar resource level is the 2021

benchmarks are Daggett, California, and Seattle, Washington. The 2020 benchmarks used the more moderate locations of Phoenix, Arizona (High) and New York City, New York (Low), which explains the widened range of outcomes. When accounting for these changes and other model updates the storage system kit costs actually decreased between 2020 and 2021. Appendix A provides a detailed discussion of the changes made to the models between last year's versions and this year's versions. 


\section{Conclusions}

NREL's bottom-up cost models can be used to assess the costs of PV and storage systems having various configurations. They can also estimate future potential cost-reduction opportunities for PV and PV-plus-storage systems, thus helping guide research and development aimed at advancing cost-effective system configurations. The data in this annual benchmarking report inform the formulation of, and track progress toward, the Solar Energy Technologies Office's Government Performance and Reporting Act cost targets.

Based on our bottom-up modeling, the Q1 2021 cost benchmarks are:

Table 13. Q1 2021 PV and Energy Storage Cost Benchmark

\begin{tabular}{|c|c|}
\hline Cost Benchmarks ${ }^{a}$ & PV System \\
\hline \multicolumn{2}{|l|}{ Residential Systems } \\
\hline$\$ 2.65 / \mathrm{W}_{\mathrm{DC}}\left(\right.$ or $\left.\$ 3.05 / \mathrm{W}_{\mathrm{AC}}\right)$ & 7.15-kWDC rooftop PV \\
\hline$\$ 4.26 / \mathrm{W}_{\mathrm{DC}}-\$ 4.72 / \mathrm{W}_{\mathrm{DC}}$ & 7.15-kWDC rooftop PV with $5 \mathrm{~kW} / 12.5 \mathrm{kWh}^{\mathrm{b}}$ nameplate of storage \\
\hline \multicolumn{2}{|l|}{ Commercial Systems } \\
\hline$\$ 1.56 / W_{D C}\left(\right.$ or $\left.\$ 1.79 / W_{A C}\right)$ & 200-kWDC rooftop PV \\
\hline$\$ 1.64 / \mathrm{W}_{\mathrm{DC}}\left(\right.$ or $\left.\$ 1.88 / \mathrm{W}_{\mathrm{AC}}\right)$ & 500-kWDC ground-mounted PV \\
\hline$\$ 1.97 / \mathrm{W}_{\mathrm{DC}}-\$ 2.06 / \mathrm{W}_{\mathrm{DC}}$ & $\begin{array}{l}\text { 1-MW } \mathrm{DC} \text { ground-mounted PV colocated with } 600 \mathrm{~kW} \mathrm{DC} / 2.4 \mathrm{MWh}_{\text {usable }} \text { of } \\
\text { storage }\end{array}$ \\
\hline \multicolumn{2}{|l|}{ Utility-Scale Systems } \\
\hline$\$ 0.83 / W_{D C}\left(\right.$ or $\left.\$ 1.09 / W_{A C}\right)$ & $100-M W_{D C}$ fixed-tilt utility-scale PV \\
\hline$\$ 0.89 / W_{D C}\left(\right.$ or $\left.\$ 1.14 / W_{A C}\right)$ & $100-M W_{D C}$ one-axis-tracking utility-scale PV \\
\hline$\$ 1.67 / \mathrm{W}_{\mathrm{DC}}-\$ 1.68 / \mathrm{W}_{\mathrm{DC}}$ & $\begin{array}{l}100-\mathrm{MW} \mathrm{DC}_{\mathrm{DC}} \text { one-axis tracker PV colocated with } 60 \mathrm{MW} \mathrm{DC} / 240 \mathrm{MWh} \text { usable } \\
\text { of storage }\end{array}$ \\
\hline
\end{tabular}

Overall, modeled installed costs of stand-alone PV and stand-alone storage systems declined slightly from Q1 2020 to Q1 2021, as shown in Figure 27 and Figure 28 (page 51). Reductions in module costs and improvements in efficiency were counterbalanced by increased raw material and residential inverter costs.

The changes in installed cost - along with changes in operation, system design, and technology - have resulted in changes in the cost of electricity (Figure ES-6). From 2020 to 2021, residential PV-plus-storage LCOE fell 13\%, ${ }^{28}$ and residential stand-alone-PV LCOE fell $9 \%$; there were $7 \%$ and $13 \%$ reductions in levelized electricity costs for commercial and utility-

\footnotetext{
${ }^{28}$ Reported 2021 residential PV plus storage LCOE values are 17\% higher than 2020 values because the 2021 report models a larger battery system $(5 \mathrm{~kW} ; 12.5 \mathrm{kWh})$ than the 2020 benchmark report $(3 \mathrm{~kW} ; 12.5 \mathrm{kWh})$. When using $2020 \mathrm{PV}$ plus storage LCOE model assumptions, the 2020 value rises from $20.1 \varnothing / \mathrm{kWh}$ to $21.5 \notin / \mathrm{kWh}$.
} 
scale PV-plus-storage systems. At the same time LCOE of commercial and utility scale standalone PV systems fell by $9 \%$ and $12 \%$ respectively.

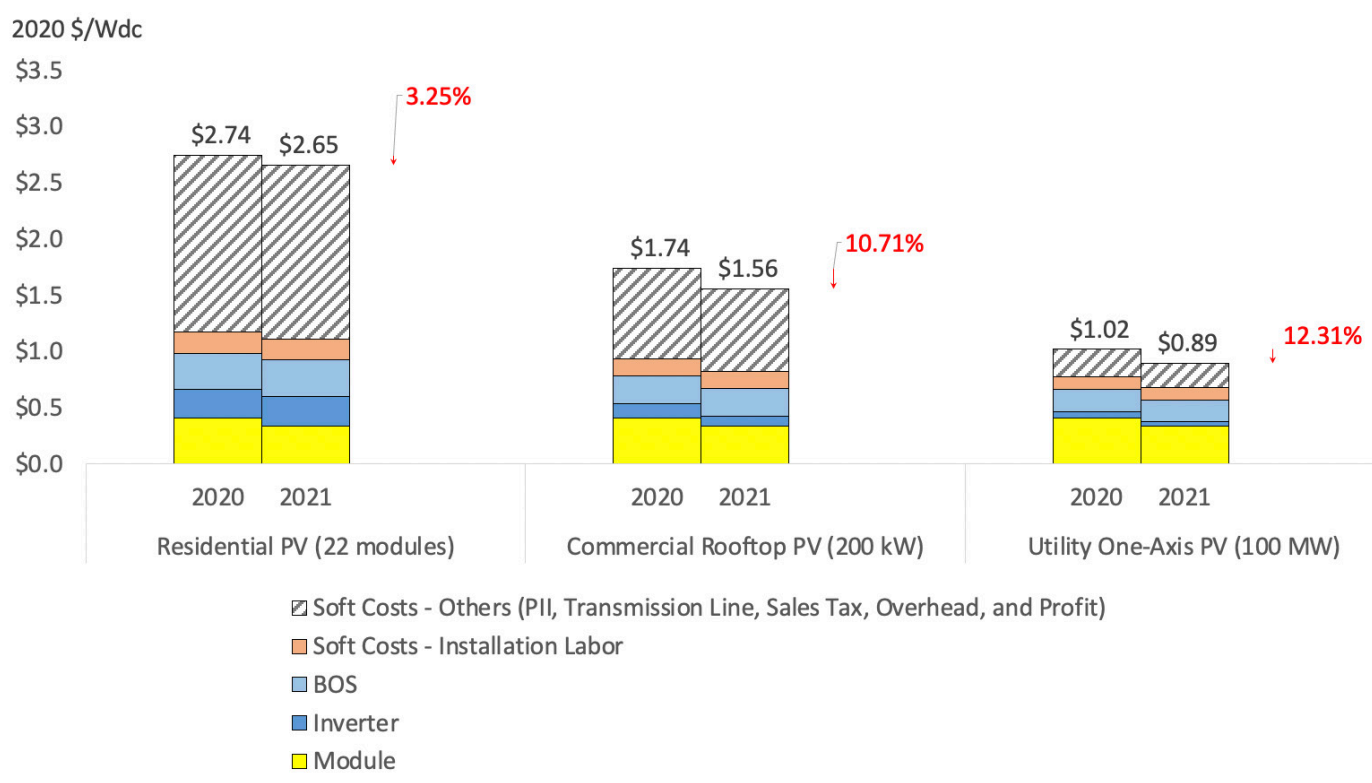

Figure 27. Comparison of Q1 2020 and Q1 2021 PV cost benchmarks

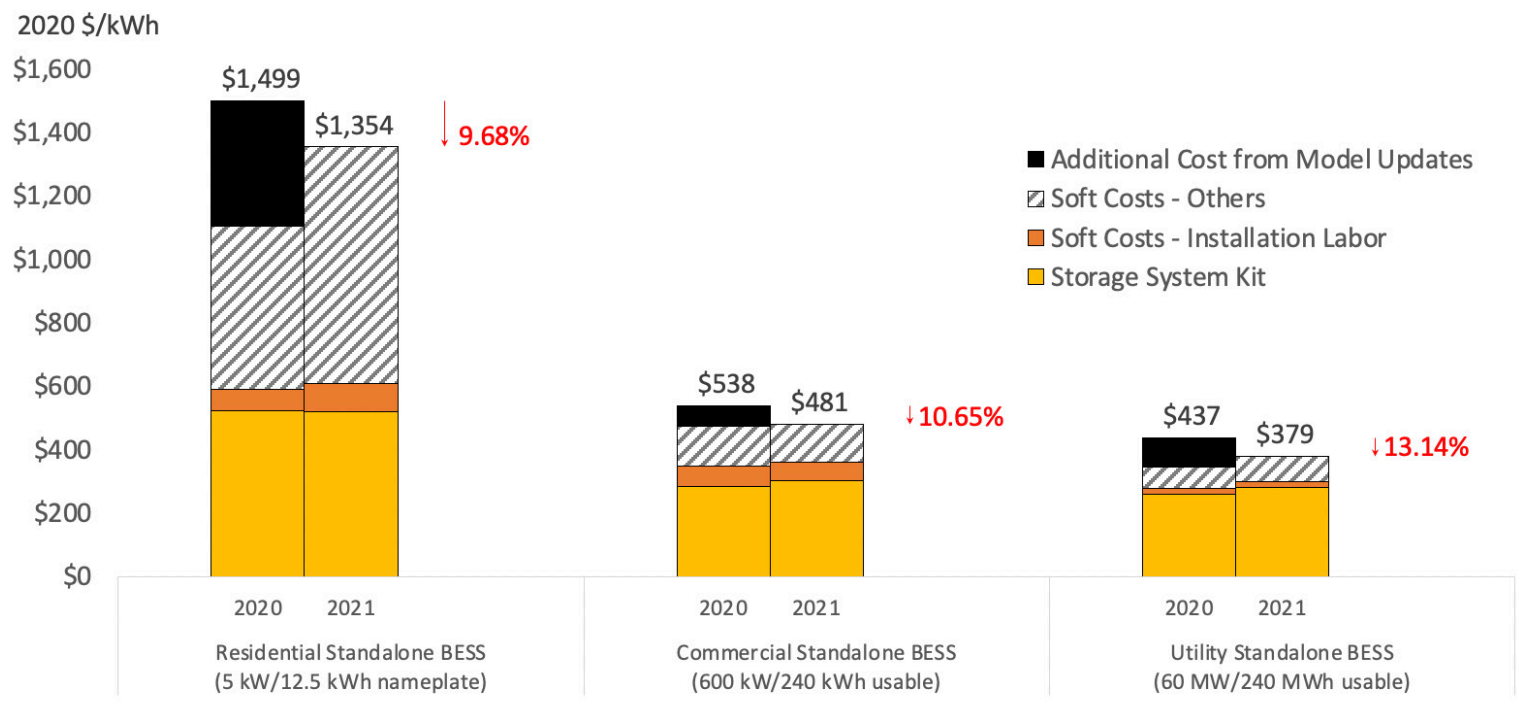

Figure 28. Comparison of Q1 2020 and Q1 2021 stand-alone BESS system cost benchmarks

All storage system costs before Q1 2021 were represented in nameplate capacity; this year, only the residential system cost is represented in nameplate capacity. The Additional Cost from model updates category for Q1 2020 commercial and utility-scale systems represents the increase in cost that is due to adding storage capacity to keep the same values $(600 \mathrm{~kW} / 240 \mathrm{kWh}, 60 \mathrm{MW} / 240 \mathrm{MWh})$ but quoting in terms of usable rather than nameplate capacity. Overbuilding battery capacity on the DC side is necessary to account for RTE loss and state of charge (SOC) limitations. 


\section{References}

Ardani, Kristen, Eric O’Shaughnessy, Ran Fu, Chris McClurg, Joshua Huneycutt, and Robert Margolis. 2017. Installed Cost Benchmark and Deployment Barriers for Residential Solar Photovoltaics with Energy Storage: Q1 2016. Golden, CO: National Renewable Energy Laboratory. NREL/TP-7A20- 67474. https://www.nrel.gov/docs/fy17osti/67474.pdf.

Barbose, Galen, Salma Elmallah, and Will Gorman. 2021. Behind the Meter Solar+Storage: Market Data and Trends. Berkeley, CA: Lawrence Berkeley National Laboratory. https://doi.org/10.2172/1810087.

Barbose, Galen, Naïm Darghouth, Eric O'Shaughnessy, and Sydney Forrester. 2020. Distributed Solar 2020 Data Update. Berkeley, CA: Lawrence Berkeley National Laboratory. https://doi.org/10.2172/1735556.

BLS (U.S. Bureau of Labor Statistics). 2020. "May 2020 National Occupational Employment and Wage Estimates United States.” Accessed May 28, 2021.

https://www.bls.gov/oes/current/oes_nat.htm.

BNEF (Bloomberg New Energy Finance). 2020. "Energy Storage System Costs Survey 2020.” December 16, 2020.

Bolinger, Mark, Joachim Seel, Dana Robson, and Cody Warner. November 2020. Utility-Scale Solar Data Update: 2020 Edition. Berkeley, CA: Lawrence Berkeley National Laboratory. https://emp.lbl.gov/sites/default/files/2020_utility-scale_solar_data_update.pdf.

CA NEM. 2021. "NEM Currently Interconnected Data Set." California Distributed Generation Statistics. Accessed June 23, 2021. http://www.californiadgstats.ca.gov/downloads.

Chung, Donald, Carolyn Davidson, Ran Fu, Kristen Ardani, and Robert Margolis. 2015. U.S. Photovoltaic Prices and Cost Breakdowns: Q1 2015 Benchmark for Residential, Commercial, and Utility-Scale Systems. NREL/TP-6A20-64746. Golden, CO: National Renewable Energy Laboratory. https://www.nrel.gov/docs/fy15osti/64746.pdf.

Cook, Jeffrey J., Jesse Cruce, Eric O'Shaughnessy, Kristen Ardani, Robert Margolis. 2021. "Exploring the Link Between Project Delays and Cancelation Rates in the U.S. Rooftop Solar Industry." Energy Policy 156: 112421. https://doi.org/10.1016/j.enpol.2021.112421.

Denholm, Paul, Josh Eichman, and Robert Margolis. 2017. Evaluating the Technical and Economic Performance of PV Plus Storage Power Plants. NREL/TP-6A20-68737. Golden, CO: National Renewable Energy Laboratory. https://www.nrel.gov/docs/fy17osti/68737.pdf.

DiOrio, Nicholas, and Will Hobbs. 2018. Economic Dispatch for DC-Connected Battery Systems on Large PV Plants. 10th PVPMC, Albuquerque, NM.

https://pvpmc.sandia.gov/download/6559/.

EIA (United States Energy Information Administration). 2021. "2020ER Form EIA-860 Detailed Data with Previous Form Data.” Released June 11, 2021. Washington, D.C.: EIA.

Enphase. 2019. Enphase quarterly presentations. Accessed October 14, 2019. https://investor.enphase.com/events-and-presentations. 
Feldman, David, Vignesh Ramasamy, Ran Fu, Ashwin Ramdas, Jal Desai, and Robert Margolis. 2021. U.S. Solar Photovoltaic System Cost Benchmark: Q1 2020. Golden, CO: National

Renewable Energy Laboratory. NREL/TP-6A20-77324.

https://www.nrel.gov/docs/fy21osti/77324.pdf.

Feldman, David, Galen Barbose, Robert Margolis, Mark Bolinger, Donald Chung, Ran Fu, Joachim Seel, Carolyn Davidson, Naïm Darghouth, and Ryan Wiser. 2015. Photovoltaic System Pricing Trends: Historical, Recent, and Near-Term Projections: 2015 Edition. NREL/PR-6A2064898. Golden, CO: National Renewable Energy Laboratory.

https://www.nrel.gov/docs/fy15osti/64898.pdf.

Fu, Ran, David Feldman, and Robert Margolis. 2018a. U.S. Solar Photovoltaic System Cost Benchmark: Q1 2018. NREL/TP-6A20-72399. Golden, CO: National Renewable Energy Laboratory. https://www.nrel.gov/docs/fy19osti/72399.pdf.

Fu, Ran, Timothy Remo, and Robert Margolis. 2018b. 2018 U.S. Utility-Scale PhotovoltaicsPlus-Energy Storage System Costs Benchmark. NREL/TP-6A20-71714. Golden, CO: National Renewable Energy Laboratory. https://www.nrel.gov/docs/fy19osti/71714.pdf.

Fu, Ran, David Feldman, Robert Margolis, Mike Woodhouse, and Kristen Ardani. 2017. U.S. Solar Photovoltaic System Cost Benchmark: Q1 2017. NREL/TP-6A20-68925. Golden, CO: National Renewable Energy Laboratory. https://www.nrel.gov/docs/fy17osti/68925.pdf.

$\mathrm{Fu}$, Ran, Donald Chung, Travis Lowder, David Feldman, Kristen Ardani, and Robert Margolis. 2016. U.S. Solar Photovoltaic System Cost Benchmark: Q1 2016. NREL/TP-6A2066532. Golden, CO: National Renewable Energy Laboratory. https://www.nrel.gov/docs/fy16osti/66532.pdf.

Fu, Ran, Ted L. James, Donald Chung, Douglas Gagne, Anthony Lopez, and Aron Dobos. 2015. "Economic Competitiveness of U.S. Utility-Scale Photovoltaic Systems in 2015: Regional Cost Modeling of Installed Cost $(\$ / \mathrm{W})$ and LCOE (\$/kWh)." Presented at the IEEE 42nd Photovoltaic Specialist Conference, New Orleans, LA. https://ieeexplore.ieee.org/document/7356261.

Gunda, T., and R. Homan. 2020. Evaluation of Component Reliability in Photovoltaic Systems using Field Failure Statistics. Albuquerque, NM: Sandia National Laboratories. SAND20209231. https://doi.org/10.2172/1660804.

Klise, Geoffrey T., Olga Lavrova, and Renee Gooding. 2018. PV System Component Fault and Failure Compilation and Analysis. Albuquerque, NM: Sandia National Laboratories. SAND2018-1743. https://doi.org/10.2172/1424887.

MEPS (MEPS International Ltd.). 2019. "MEPS: North American Carbon Steel Purchasing Price Index (SPPI).” Accessed October 18, 2019. http://www.meps.co.uk/N.Amer\%20Index.htm.

NREL (National Renewable Energy Laboratory). 2021. NREL dialogues and interviews with solar industry collaborators. Golden, CO: National Renewable Energy Laboratory.

NREL (National Renewable Energy Laboratory), Sandia National Laboratories, SunSpec Alliance, and the SunShot National Laboratory Multiyear Partnership (SuNLaMP) PV O\&M Best Practices Working Group. 2018. Best Practices for Operation and Maintenance of 
Photovoltaic and Energy Storage Systems, 3rd Edition. NREL/TP-7A40-73822. Golden, CO: National Renewable Energy Laboratory. https://www.nrel.gov/docs/fy19osti/73822.pdf.

RSMeans. 2021. Building Construction Costs with RSMeans data. 79th Annual Edition.

Schwab, Amy, Andy Walker, and Jal Desai. 2020. Insurance in the Operation of Photovoltaic Plants. Golden, CO: National Renewable Energy Laboratory. NREL/TP-6A20-78588. https://www.nrel.gov/docs/fy21osti/78588.pdf.

Sonnen Batterie. 2018. "Sonnen Batterie Smart Energy Storage for Homeowners." Accessed April 10, 2018: https://sonnen-batterie.com/en-us/sonnenbatterie.

Walker, Andy, Eric Lockhart, Jal Desai, Kristen Ardani, Geoff Klise, Olga Lavrova, Tom Tansy et al. 2020. Model of Operation and Maintenance Costs for Photovoltaic Systems. NREL/TP5C00-74840. Golden, CO: National Renewable Energy Laboratory. https://www.nrel.gov/docs/fy20osti/74840.pdf.

Wiser, Ryan H, Mark Bolinger, and Joachim Seel. 2020. Benchmarking Utility-Scale PV Operational Expenses and Project Lifetimes: Results from a Survey of U.S. Solar Industry Professionals. Berkeley, CA: Lawrence Berkeley National Laboratory. https://emp.lbl.gov/publications/benchmarking-utility-scale-pv.

Wood Mackenzie. 2019. Solar-Plus-Storage System Architectures: Design, Pricing, and Economics in the U.S.

Wood Mackenzie and SEIA (Solar Energy Industries Association). 2021. U.S. Solar Market Insight Report, Q2 2021. Washington, D.C.: Solar Energy Industries Association. https://www.woodmac.com/research/products/power-and-renewables/us-solar-market-insight/. 


\section{Appendix A. Changes in Methodology Between Q1 2020 and Q1 2021 Reports}

Since 2010, NREL has performed PV system benchmark calculations. Each year we endeavor to improve the modeling to better characterize the U.S. market and the costs associated with installing (and operating, in the case of LCOE) residential, commercial, and utility-scale standalone PV, stand-alone storage, and PV-plus-storage systems. This appendix summarizes the major changes we made in the models between the publication of the Q1 2020 and Q1 2021 reports.

\section{Different Methodology for Calculating Commercial and Utility-Scale Transmission and Interconnection Costs}

For this year's version of our benchmarking analysis, we updated interconnection and transmission costs from estimates using $\mathrm{MW}_{\mathrm{DC}}$ to estimates based on the defined point of interconnection capacity and assumed it is equal to the total AC capacity of the plant (MW $\mathrm{MC}_{\mathrm{AC}}$.

\section{Different Methodology for Calculating Li-Ion Battery Costs}

In previous year's benchmarks, Li-ion battery costs only represented their nameplate capacity without any upfront augmentation. For this year's version of our benchmarking analysis, we assume a DC overbuild accounting for RTE loss (10\%) and state of charge limitations (20\%); we assume the battery is shipped as a cabinet enclosure with all battery components preassembled; finally, we recategorize the container, racks, HVAC, thermal management system and battery management system previously included as a part of SBOS cost category into the cost of the Liion battery.

\section{Changed Standard Size of Residential Li-ion Battery Capacity}

In previous year's benchmarks, we calculated residential PV-plus-storage systems assuming a battery capacity of either $3 \mathrm{~kW} / 6 \mathrm{kWh}$ or $5 \mathrm{~kW} / 20 \mathrm{KWh}$. For this year's version of our benchmarking analysis, we assume a battery size of $5 \mathrm{~kW} / 12.5 \mathrm{kWh}$. The adjustment was made to conform with typical battery size currently available in marketplace (Barbose et al. 2021).

\section{Changed Assumptions for Calculating Capacity Factor}

The medium solar resource values were changed to better correspond with U.S. national averages. Low and high resource locations were made to show a wider range in solar resources available in the United States. We also adjusted PV system loss assumptions to better correspond with default assumptions in other NREL modeling applications. Finally, we adjusted tilt and azimuth assumptions for residential and commercial rooftop systems to better correspond to national averages (Barbose et al. 2020).

Table A-1 summarizes the current and previous methods. 
Table A-1. Changes in Capacity Factor Methodology Between Q1 2020 and Q1 2021 Reports

\begin{tabular}{|c|c|c|}
\hline $\begin{array}{l}\text { Cost Category (All } \\
\text { Sectors) }\end{array}$ & $\begin{array}{l}\text { Q1 } 2020 \text { Model: Summary of Method } \\
\text { (Value) }\end{array}$ & $\begin{array}{l}\text { Q1 } 2021 \text { Model: Summary of Method } \\
\text { (Value) }\end{array}$ \\
\hline \multirow[t]{6}{*}{ Capacity Factor } & $\begin{array}{l}\text { Low solar resource: New York City, } \\
\text { New York }\end{array}$ & $\begin{array}{l}\text { Low solar resource: } \\
\text { Seattle, Washington }\end{array}$ \\
\hline & $\begin{array}{l}\text { Medium solar resource: Kansas } \\
\text { City, Missouri }\end{array}$ & $\begin{array}{l}\text { Medium solar resource: Fredonia, } \\
\text { Kansas (near the geographic center of } \\
\text { the } 48 \text { conterminous states and } \\
\text { corresponds with the area-weighted } \\
\text { capacity factor of the } 48 \text { conterminous } \\
\text { states as outlined in the } 2021 \text { Annual } \\
\text { Technology Baseline) }\end{array}$ \\
\hline & High Solar resource: Phoenix, Arizona & High Solar resource: Daggett, California \\
\hline & $\begin{array}{l}\text { Tilt/azimuth: } 25 / 180 \text { (residential), 10/180 } \\
\text { (commercial rooftop), and tracking/180 } \\
\text { (utility-scale). }\end{array}$ & $\begin{array}{l}\text { Tilt/azimuth of } 20 / 214 \text { (residential) } \\
\text { (Barbose et al. 2020), 10/190 } \\
\text { (commercial rooftop) (Barbose et al. } \\
\text { 2020), and tracking/180 (utility-scale). }\end{array}$ \\
\hline & & Preinverter derate: $85.9 \%$ \\
\hline & Preinverter derate: $90.5 \%$ & Inverter Efficiency: 96\% \\
\hline
\end{tabular}

\section{Changed Assumptions for Calculating Residential Financial Costs, Lifetime, and Degradation}

The percentage of host-owned PV systems has increased substantially over the past 5 years $(63 \%$ of residential PV systems in 2019), and most of these owners finance the cost through the use of a personal loan. Though mortgages are not currently the most prevalent source of funding, they represent a major opportunity for cost reductions for PV system costs, and therefore we view this as reasonable long-term steady-state financing assumption. Because of host-ownership, we assume the homeowner does not spend as much time and effort on maintaining the PV system as a third-party and therefore O\&M cost are reduced, while degradation rate increases, and system lifetime decreases.

Table A-2 summarizes the current and previous methods.

Table A-2. Changes in Residential PV LCOE Methodology Between Q1 2020 and Q1 2021 Reports

\section{Cost Category (All Q1 2020 Model: Summary of Method Sectors) (Value) \\ Q1 2021 Model: Summary of Method (Value)}

Residential Financial Model Assumptions
Third-party ownership of residential PV system:

- Equity discount rate (real): $6.1 \%$

- Debt interest rate: $5.0 \%$

- Debt fraction: $71.8 \%$

- Debt term: 18 years
Homeowner owns residential PV system and finances cost through their mortgage:

- Equity discount rate (real): $10.2 \%$

- Debt interest rate: $4.5 \%$

- Debt fraction: $100.0 \%$

- Debt term: 25 years 
Cost Category (All Q1 2020 Model: Summary of Method Sectors)

(Value)
- Entity: corporation

- Analysis period: 30 years

- Annual degradation: $0.7 \% / y r$
Q1 2021 Model: Summary of Method (Value)

- Entity: homeowner

- Analysis period: 25 years

- Annual degradation: $1.0 \% / y r$

\section{Changed Labor Wage Assumptions}

In previous year's benchmarks, we used the average U.S. Bureau of Labor Statistics (BLS) labor wages by occupation across all states in United States. For this year's version of our benchmarking analysis, we use U.S. labor wage by occupation from BLS; instead of calculating average labor rate of all states, we use BLS reported value for the United States.

\section{Changed Assumptions for Calculating O\&M}

For this year's version of our benchmarking analysis, we revised certain line items and costs. Specifically, we adjusted: the analysis period, labor rates, module and inverter replacement costs, discount rate, inflation rate, capital expenditures, module power and efficiency, degradation rates, warranty period, cost of aerial inspection, and property insurance premium. Additionally, based on high-level market research, some of the original 133 line item measures were deleted because they were either dated or not applicable to certain type of systems - especially for residential and utility systems (one-axis tracking).

\section{Changes to the Cost Categorization in PV Plus Storage Cost Models}

To match the calculation methodology of PV bottom-up cost models: Site Staging and DC to DC converter cost is included under EBOS cost category, EPC overhead markup on module, inverter and battery cost is excluded from EPC overhead calculation, EPC overhead and profit markup on labor cost are excluded from EPC overhead and profit margin calculation.

The changes summarized in this appendix result in Q1 2020 and Q1 2021 benchmarks with different results than would have been calculated using the previous edition's models and assumptions, particularly for commercial and utility-scale PV-plus-storage systems. To better distinguish the historical cost trends from the changes to our cost models, we also calculate Q1 2020 PV-plus-storage system cost benchmarks for commercial and utility-scale PV-plus-storage systems using the previous and current model versions.

Table A-3 summarizes the impacts these changes have on each cost category in the commercial and utility-scale PV plus Storage benchmarks for Q1 2020. 
Table A-3. Comparison of Q1 2020 Benchmark Costs, per Category, of Commercial and Utility PV Plus Storage Systems Calculated Using Previous Report's Model (Q1 2020) and the Current Model (Q1 2021) in 2020 USD

\begin{tabular}{|c|c|c|c|c|c|c|c|c|c|c|c|c|}
\hline & \multicolumn{3}{|c|}{$\begin{array}{l}\text { Commercial DC Coupled } \\
\left(\$ / W_{D C} Q 12020\right)\end{array}$} & \multicolumn{3}{|c|}{$\begin{array}{l}\text { Commercial AC Coupled } \\
\left(\left(\$ / W_{D C} Q 12020\right)\right.\end{array}$} & \multicolumn{3}{|c|}{$\begin{array}{l}\text { Utility DC Coupled } \\
\left(\left(\$ / W_{D C} Q 12020\right)\right.\end{array}$} & \multicolumn{3}{|c|}{$\begin{array}{l}\text { Utility AC Coupled } \\
\left(\left(\$ / W_{D C} Q 12020\right)\right.\end{array}$} \\
\hline & $\begin{array}{l}\text { Q1 } 2020 \\
\text { Model }\end{array}$ & $\begin{array}{l}\text { Q1 } 2021 \\
\text { Model }\end{array}$ & $\begin{array}{c}\% \\
\text { Change }\end{array}$ & $\begin{array}{l}\text { Q1 } 2020 \\
\text { Model }\end{array}$ & $\begin{array}{l}\text { Q1 } 2021 \\
\text { Model }\end{array}$ & $\begin{array}{c}\% \\
\text { Change }\end{array}$ & $\begin{array}{c}\text { Q1 } \\
2020 \\
\text { Model }\end{array}$ & $\begin{array}{c}\text { Q1 } \\
2021 \\
\text { Model }\end{array}$ & $\begin{array}{c}\% \\
\text { Change }\end{array}$ & $\begin{array}{c}\text { Q1 } \\
2020 \\
\text { Model }\end{array}$ & $\begin{array}{c}\text { Q1 } \\
2021 \\
\text { Model }\end{array}$ & $\begin{array}{c}\% \\
\text { Change }\end{array}$ \\
\hline PV Module & 0.411 & 0.410 & $0 \%$ & 0.411 & 0.410 & $0 \%$ & 0.411 & 0.410 & $0 \%$ & 0.411 & 0.410 & $0 \%$ \\
\hline Li-Ion Battery/Cabinets & 0.467 & 0.642 & $38 \%$ & 0.467 & 0.642 & $38 \%$ & 0.467 & 0.631 & $35 \%$ & 0.467 & 0.631 & $35 \%$ \\
\hline Solar Inverter & 0.000 & 0.000 & $0 \%$ & 0.072 & 0.072 & $0 \%$ & 0.000 & 0.000 & $0 \%$ & 0.052 & 0.050 & $0 \%$ \\
\hline Bidirectional Inverter & 0.036 & 0.036 & $0 \%$ & 0.036 & 0.036 & $0 \%$ & 0.036 & 0.036 & $0 \%$ & 0.036 & 0.036 & $0 \%$ \\
\hline Structural BOS & 0.182 & 0.124 & $-32 \%$ & 0.175 & 0.138 & $-21 \%$ & 0.161 & 0.132 & $-18 \%$ & 0.155 & 0.127 & $-18 \%$ \\
\hline Electrical BOS & 0.228 & 0.318 & $40 \%$ & 0.192 & 0.301 & $56 \%$ & 0.136 & 0.172 & $27 \%$ & 0.105 & 0.168 & $61 \%$ \\
\hline Installation labor & 0.274 & 0.240 & $-13 \%$ & 0.100 & 0.080 & $-20 \%$ & 0.157 & 0.144 & $-9 \%$ & 0.136 & 0.113 & $-16 \%$ \\
\hline EPC Overhead & 0.163 & 0.089 & $-46 \%$ & 0.131 & 0.068 & $-48 \%$ & 0.080 & 0.058 & $-27 \%$ & 0.069 & 0.053 & $-23 \%$ \\
\hline Sales Tax & 0.084 & 0.092 & $10 \%$ & 0.086 & 0.097 & $13 \%$ & 0.077 & 0.083 & $8 \%$ & 0.078 & 0.085 & $9 \%$ \\
\hline Permitting Fee & 0.008 & 0.009 & $14 \%$ & 0.008 & 0.009 & $14 \%$ & 0.002 & 0.002 & $-8 \%$ & 0.002 & 0.002 & $-6 \%$ \\
\hline Interconnection Fee & 0.028 & 0.017 & $-40 \%$ & 0.029 & 0.017 & $-40 \%$ & 0.028 & 0.025 & $-11 \%$ & 0.028 & 0.026 & $-10 \%$ \\
\hline Transmission Line & 0.000 & 0.000 & $0 \%$ & 0.000 & 0.000 & $0 \%$ & 0.017 & 0.020 & $18 \%$ & 0.017 & 0.020 & $18 \%$ \\
\hline Contingency & 0.056 & 0.047 & $-17 \%$ & 0.055 & 0.049 & $-10 \%$ & 0.047 & 0.043 & $-9 \%$ & 0.047 & 0.044 & $-5 \%$ \\
\hline Developer Overhead & 0.056 & 0.094 & $66 \%$ & 0.055 & 0.098 & $79 \%$ & 0.047 & 0.058 & $22 \%$ & 0.047 & 0.059 & $26 \%$ \\
\hline EPC/Developer Profit & 0.150 & 0.137 & $-9 \%$ & 0.155 & 0.143 & $-8 \%$ & 0.083 & 0.077 & $-8 \%$ & 0.082 & 0.079 & $-5 \%$ \\
\hline Total price & 2.154 & 2.265 & $5 \%$ & 2.092 & 2.171 & $4 \%$ & 1.750 & 1.901 & $9 \%$ & 1.732 & 1.904 & $10 \%$ \\
\hline
\end{tabular}




\section{Appendix B. PV System CAPEX and LCOE Benchmarks in 2020 USD}

When comparing the results across periods, note that:

1. Values are inflation-adjusted using the Consumer Price Index (2020). Thus, historical values from our models are adjusted and presented as real USD instead of nominal USD.

2. Cost categories are aggregated for comparison purposes. Soft Costs_-Others represents:
A. PII
B. Transmission line (if any)
C. Sales tax
D. EPC/developer overhead and profit.

3. The current versions of our cost models make a few significant changes from the versions used in our Q1 2020 (Feldman et. al. 2021) and Q1 2018 benchmarking reports (Fu et al. 2018a, Fu et al. 2018b). Appendix A details the changes made to the models between previous versions (Feldman et al. 2021) and this year's versions.

4. Our Q1 2019, Q1 2020, and Q1 2021 benchmarks use monocrystalline PV modules, whereas all previous benchmarks used multicrystalline PV modules. This switch reflects the overall trend occurring in the U.S. market.

5. Based on Wiser, Bolinger, and Seel (2020), which stated that most utility-scale PV projects do not own the land on which the PV system is placed, we reclassified land costs from an upfront capital expenditure (land acquisition) to an operating expenditure (lease payments) for 2019, 2020, and 2021. In previous editions of this report, we assumed a land acquisition cost of $\$ 0.03 / \mathrm{W}$.

All previous benchmarks can be found at NREL's "Solar Technology Cost Analysis" web page at www.nrel.gov/solar/solar-cost-analysis.html.

We use the following equation to calculate LCOE of PV plus storage system as follows:

$$
\begin{aligned}
& L C O E \\
& =\frac{E+\frac{F^{n}}{(1+R)^{n}}-\sum_{n-1}^{N} \frac{(D+D F)^{n}}{(1+R n)^{n}} \times(T)+\sum_{n-1}^{N} \frac{(O+C+I)^{n}}{(1+R n)^{n}} \times(1-T)-\frac{R v^{n}}{(1+R)^{n}} \times(1-T)+\sum_{n-1}^{N} \frac{(P)^{n}}{(1+R n)^{n}} \times(1-T)}{\left(\sum_{n-1}^{N} \frac{P \times(1-D r)^{n}}{(1+R)^{n}} \times(1-B)+\sum_{n-1}^{N} \frac{P \times(1-D r)^{n}}{(1+R)^{n}} \times(B) \times(1-L p)+\sum_{n-1}^{N} \frac{G}{(1+R)^{n}} \times(1-L g)\right) \times(1-\mathrm{T})}
\end{aligned}
$$

\section{Equation 1. LCOE of PV plus storage formula}

$E=$ Initial equity investment of solar and storage

$I=$ Debt interest payments

$P=$ Debt principal payments

$C=$ Charging cost

$F=$ Follow-on investments (inverter, battery replacements)

$D=$ Depreciation of solar and storage (which may include depreciation from follow-on

investments)

$R=$ Real discount rate 


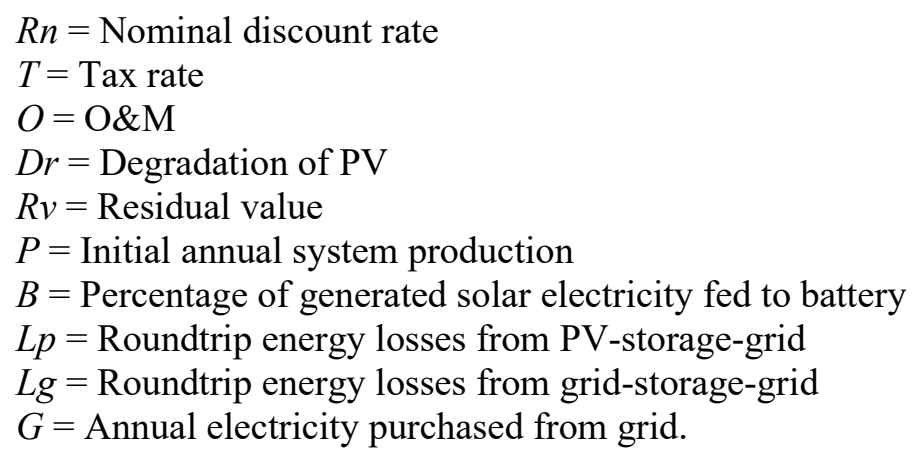

Table B-1 (CAPEX) and Table B-2 (LCOE) put our Q1 2021 benchmarking results (inflationadjusted) in context with the results of previous National Renewable Energy Laboratory (NREL) benchmarking analyses. 
Table B-1. Summary of NREL CAPEX (2020 $\left.\$ / W_{D C}\right)$

\begin{tabular}{|c|c|c|c|c|c|c|c|c|c|c|c|c|}
\hline $\begin{array}{l}\text { Reporting Year } \\
\text { (Benchmarking Date) }\end{array}$ & 응 & 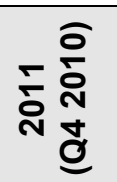 & 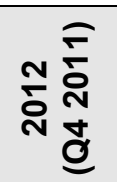 & 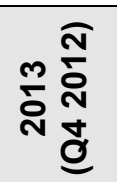 & 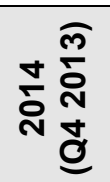 & 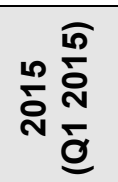 & 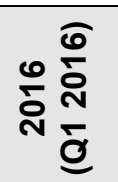 & 둥 $\frac{\widetilde{N}}{\frac{N}{\sigma}}$ & 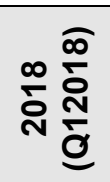 & 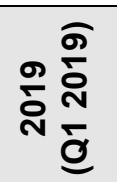 & 尽 & స్ণ \\
\hline Residential (22-panel) & 9.01 & 7.83 & 5.35 & 4.60 & 4.00 & 3.71 & 3.44 & 3.12 & 2.90 & 2.84 & 2.71 & 2.65 \\
\hline Commercial Rooftop (200-kW) & 6.67 & 6.13 & 4.08 & 3.26 & 3.21 & 2.64 & 2.50 & 2.07 & 1.84 & 1.80 & 1.72 & 1.56 \\
\hline Utility-Scale (100-MW fixed-tilt) & 5.69 & 4.83 & 3.17 & 2.39 & 2.19 & 2.12 & 1.67 & 1.15 & 1.13 & 0.97 & 0.94 & 0.83 \\
\hline Utility-Scale (100-MW one-axis tracking) & 6.78 & 5.66 & 3.76 & 2.81 & 2.49 & 2.29 & 1.77 & 1.24 & 1.21 & 1.04 & 1.01 & 0.89 \\
\hline
\end{tabular}

Table B-2. Summary NREL LCOE (2020 cents/kWh)

\begin{tabular}{|c|c|c|c|c|c|c|c|c|c|c|c|c|c|c|}
\hline \multirow[b]{2}{*}{$\begin{array}{l}\text { Reporting Year } \\
\text { (Benchmarking Date) }\end{array}$} & \multicolumn{11}{|c|}{ Market Financing Rates } & \multicolumn{3}{|c|}{$\begin{array}{l}\text { Steady- } \\
\text { State Financing }\end{array}$} \\
\hline & 융 & 휴 & $\stackrel{\widetilde{\sigma}}{\text { N }}$ & 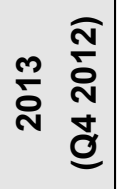 & 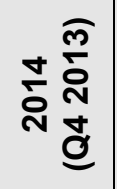 & 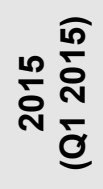 & ํㅜㅇ & 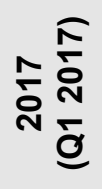 & $\stackrel{\infty}{\frac{\infty}{\delta}} \frac{\infty}{\delta}$ & 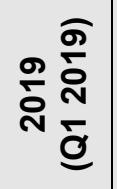 & م્స్ & 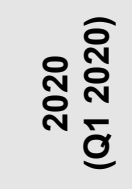 & ז্ণ & 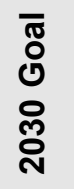 \\
\hline \multicolumn{15}{|l|}{ Residential PV (22-panel) } \\
\hline LCOE (High resource) & 42.1 & 35.4 & 24.4 & 20.5 & 17.2 & 15.2 & 13.9 & 13.1 & 12.2 & 11.3 & 11.1 & 10.6 & 9.7 & - \\
\hline LCOE (Medium resource) & 51.6 & 43.4 & 29.9 & 25.0 & 21.0 & 18.6 & 17.1 & 16.0 & 14.9 & 13.8 & 13.7 & 13.0 & 11.9 & 5.4 \\
\hline LCOE (Low resource) & 55.4 & 46.6 & 32.1 & 26.9 & 22.6 & 19.9 & 18.3 & 17.2 & 16.0 & 14.8 & 14.7 & 13.9 & 15.8 & - \\
\hline \multicolumn{15}{|c|}{ Residential PV-Plus-Storage } \\
\hline LCOE (High resource) & - & - & - & - & - & - & - & - & - & - & 16.6 & 25.4 & 16.7 & - \\
\hline LCOE (Medium resource) & - & - & - & - & - & - & - & - & - & - & 20.1 & 23.6 & 20.5 & - \\
\hline LCOE (Low resource) & 一 & 一 & - & - & - & 一 & - & - & - & - & 22.0 & 19.1 & 27.7 & 一 \\
\hline \multicolumn{15}{|c|}{ Commercial Rooftop PV (200 kW) } \\
\hline LCOE (High resource) & 32.3 & 28.8 & 19.5 & 15.3 & 14.5 & 11.6 & 10.8 & 9.4 & 9.0 & 8.0 & 7.8 & 7.4 & 6.8 & - \\
\hline LCOE (Medium resource) & 40.2 & 35.8 & 24.2 & 19.1 & 18.0 & 14.4 & 13.5 & 11.6 & 11.2 & 9.6 & 9.4 & 9.1 & 8.3 & 4.3 \\
\hline
\end{tabular}

61 


\begin{tabular}{|c|c|c|c|c|c|c|c|c|c|c|c|c|c|c|}
\hline \multirow[b]{2}{*}{ LCOE (Low resource) } & \multicolumn{11}{|c|}{ Market Financing Rates } & \multicolumn{3}{|c|}{$\begin{array}{l}\text { Steady- } \\
\text { State Financing }\end{array}$} \\
\hline & 43.3 & 38.6 & 26.1 & 20.5 & 19.4 & 15.5 & 14.5 & 12.5 & 12.0 & 10.7 & 10.5 & 9.8 & 11.2 & - \\
\hline \multicolumn{15}{|c|}{ Commercial PV-Plus-Storage } \\
\hline LCOE (High resource) & - & - & - & - & - & - & - & - & - & - & 9.3 & 9.2 & 9.2 & 一 \\
\hline LCOE (Medium resource) & - & - & - & - & - & - & - & - & - & - & 11.5 & 12.2 & 11.4 & 一 \\
\hline LCOE (Low resource) & - & - & - & - & - & - & - & - & - & - & 12.3 & 14.3 & 15.6 & - \\
\hline \multicolumn{15}{|c|}{ Utility-Scale PV (100 MW One-Axis Tracking) } \\
\hline LCOE (High resource) & 22.8 & 18.8 & 12.9 & 9.8 & 8.6 & 7.7 & 6.1 & 4.7 & 4.4 & 3.7 & 3.7 & 3.6 & 3.2 & - \\
\hline LCOE (Medium resource) & 29.3 & 24.2 & 16.6 & 12.5 & 11.0 & 9.9 & 7.8 & 6.0 & 5.7 & 4.8 & 4.8 & 4.6 & 4.1 & 2.0 \\
\hline LCOE (Low resource) & 31.8 & 26.3 & 18.0 & 13.6 & 11.9 & 10.7 & 8.5 & 6.5 & 6.2 & 5.2 & 5.2 & 5.0 & 5.5 & - \\
\hline \multicolumn{15}{|c|}{ Utility-Scale PV-Plus-Storage } \\
\hline LCOE (High resource) & - & - & - & - & - & - & - & - & - & - & 6.5 & 6.9 & 6.0 & - \\
\hline LCOE (Medium resource) & - & - & - & - & - & - & - & - & - & - & 8.5 & 8.9 & 7.7 & - \\
\hline LCOE (Low resource) & - & - & - & - & - & - & - & - & - & - & 9.2 & 9.7 & 10.7 & - \\
\hline
\end{tabular}

